
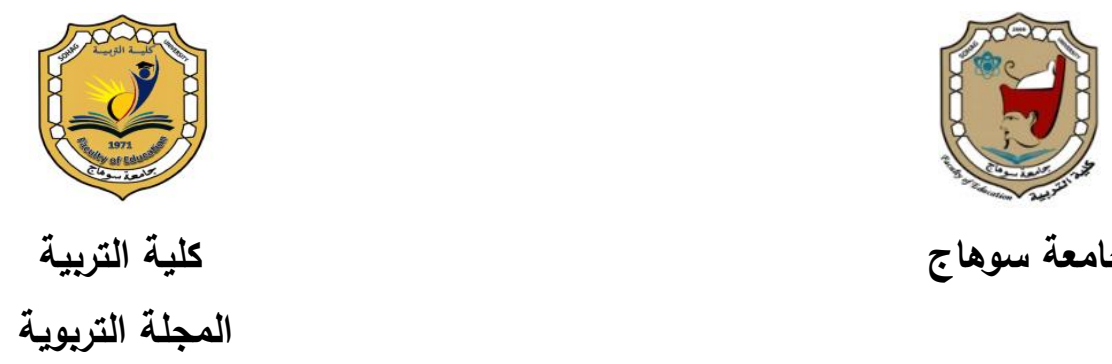

جامعة سوهاج

فاعلية إستراتيجية دائرة التعلم المدعوهة بالأنشطة الإثرائية التقنية في تنهية هفاهيم علم الفرائض وههارات التفكير الرياضي لدى طالبات الشريعة والقانون بجامعة الأزهر

$$
\begin{aligned}
& \text { إعداد } \\
& \text { د إيمان عبد الرحمن حسين محمد إدي } \\
& \text { مدرس مناهج وطرق تدريس العلوم الثرعية } \\
& \text { كلية التربية بنات - جامعة أسيوط }
\end{aligned}
$$

تاريخ الاستلام : \& سبتمبر اYr.rم

DOI: 10.12816/EDUSOHAG.2021. 


\section{ملخص البجث - اث}

هدف البحث الحـالي التعرف على فاعليـة إستراتيجية دائرة التعلم المدعومـة بالأنشطة

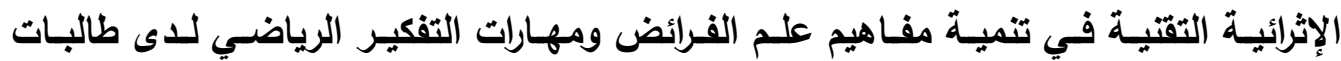

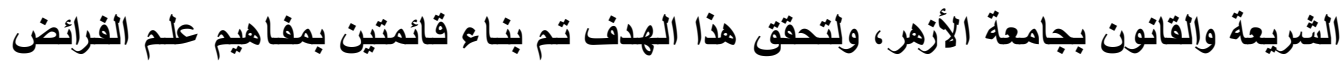

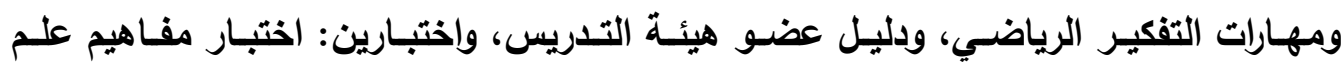
الفرائض، ومهارات التفكير الرياضي، وتم تطبيق أدوات البحث قبليا وتطبيق الإستراتيجية ثم إعادة تطبيق الاختبارين على عينة من طالبات الشريعة والقانون بأسيوط. وقد توصل البحث لجملة من النتائج من أهمها:

- وجود فروق ذات دلالة إحصائية بين متوسطي درجات طالبات المجموعة التجريبية في التطبيقين القبلي والبعدي لاختبار مفاهيم علم الفرائض لصالح التطبيق البعدي. - مجود فروق ذات دلالة إحصائية بين متوسطي درجات طالبات المجموعة التجريبية

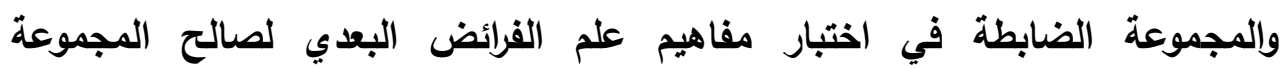
التجريبية. - مجود فروق ذات دلالة إحصائية بين متوسطي درجات طالبات المجموعة التجريبية في التطبيقين القبلي والبعدي لاختبار مهارات التفكير الرياضي لصالح التطبيق البعدي. - وجود فروق ذات دلالة إحصائية بين متوسطي درجات طالبات المجموعة التجريبية والمجموعة الضابطة في اختبار مهارات التفكير الرياضي البعدي لصالح المجموعة التجريبية.

منهج البحث ومتغيراته والتصميم التجريبي المستخدم: اعتمد البحث على المنهج التجريبي؛ وذلك بغرض التعرف على فاعلية المتغير المستقل (إستراتيجية دائرة التعلم المدعومة بالأنشطة الإثرائية التقنية) على المتغيرات التابعة للبحث، والمتمثلة في (اختباري مفاهيم علم الفرائض، ومهارات التفكير الرياضي)، أما عن التصميم التجريبي للبحث فتبنت الإنته

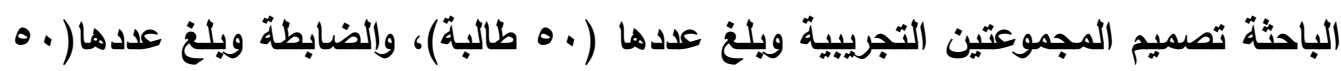
طالبة) ذي التطبيقين القبلي والبعدي.

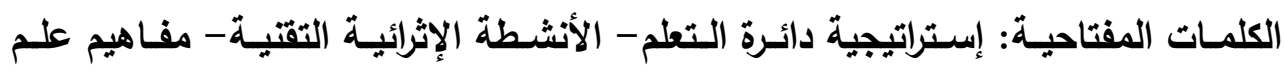
الفرائض - مهارات التفكير الرياضي. 
The effectiveness of the learning circle strategy supported by technical enrichment activities in developing the concepts of obligatory science and mathematical thinking skills among students of Sharia and law at Al-Azhar University

\section{Research Summary}

The aim of the current research is to identify the effectiveness of the learning department strategy supported by technical enrichment activities in developing the concepts of obligatory science and mathematical thinking skills among students of Sharia and law at Al-Azhar University.

The research reached a number of results, the most important of which are:

- There are statistically significant differences between the mean scores of the experimental group students in the pre and post applications for testing the concepts of obligatory science in favor of the post application.

- There are statistically significant differences between the mean scores of the students of the experimental group and the control group in testing the concepts of post-mortem science in favor of the experimental group.

- There are statistically significant differences between the mean scores of the experimental group students in the pre and post applications for testing mathematical thinking skills in favor of the post application.

- There are statistically significant differences between the mean scores of the experimental group and the control group in the post-mathematical thinking skills test in favor of the experimental group.

Research method and its variables and the experimental design used: The research relied on the experimental method; In order to identify the effectiveness of the independent variable (the learning circle strategy supported by technical enrichment activities) on the variables affiliated with the research, which are (exams of concepts of obligatory science, and mathematical thinking skills),

As for the experimental design of the research, the researcher adopted the design of the two experimental groups, which numbered ( 50 female students), and the control group (50 female students), with both pre and post applications.

Keywords: learning circle strategy- technical enrichment activitiesconcepts of obligatory science- mathematical thinking skills. 


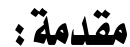

يتميز خريج الأزهر الثريف عن غيره بما يارسـه من علوم شرعية توسـع مداركه وتهذب

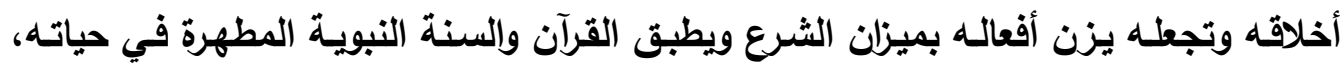
مهتديًا في ذلك بما درسده من علوم الفقه والحديث والسيرة النبوية المطهرة وغيرها. ولا شك أن علم الفرائض من أهم وأنفع العلوم التي تدرّس في الأزهر الشريف، لمـا لـه من

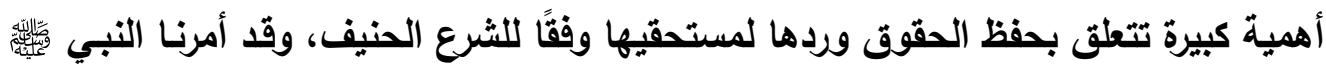

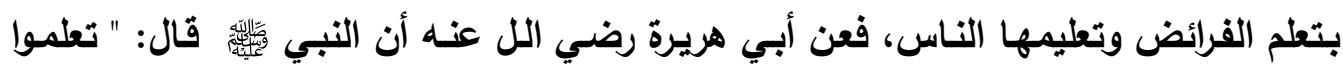
الفرائض وعلموها فإنها نصف العلم وهو ينسى وهو أول شيء ينزع من أمتي " (رواه ابن ماجه والدار قطني).

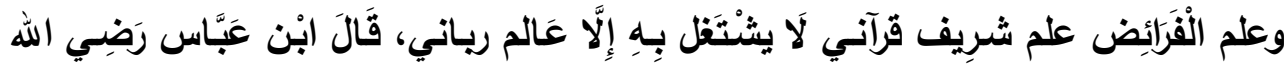

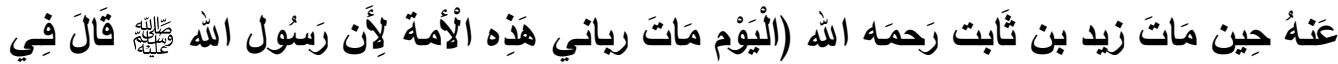

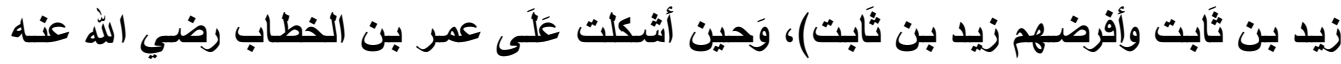

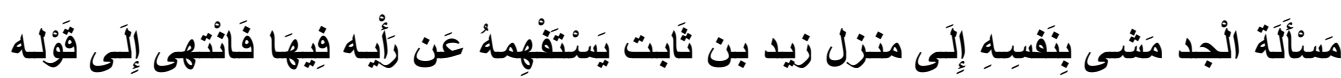

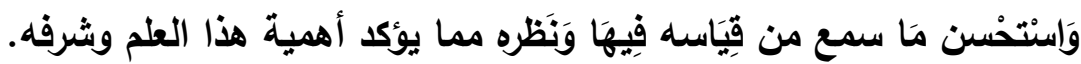

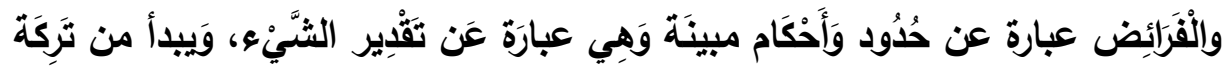

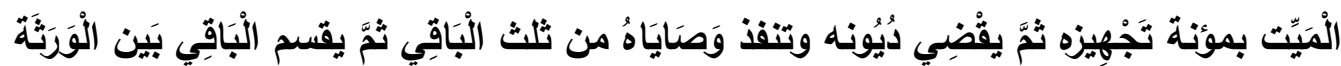

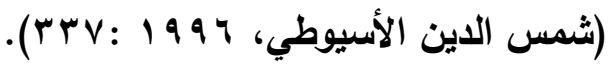
وموضوعه تركة الميث من حيث تقسيمها وبيان نصيب كل وارث، وهو من أرفع العلوم،

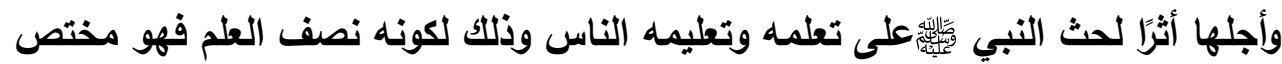
بإحدى حالتي الإنسان "حالة الممات" بخلاف غيره من العلوم، كما يتعلق بالملك الاضطراري،

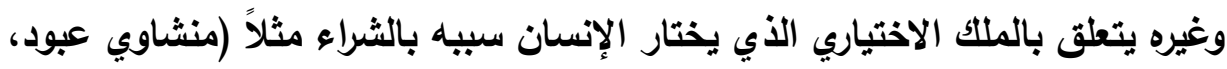
$\cdot(\varepsilon: r \cdot 19$ وقد جعل الله للفرائض نظامًا قويمًا وقانونًا حكيمًا يفيض رحمـة وعدلاً وسداداً ورشدًا، وتجد النفوس فيه مثثلاً رائعًا للهـدي القيم والعظة النافذة والحكمـة البالغة ويمكن إجمال ذلك فيمـا 
1. حكم الإسلام بجعل تركة الميث ملكًا لأفراد ورثته وفي ذلك احترام لملكية الأفراد.

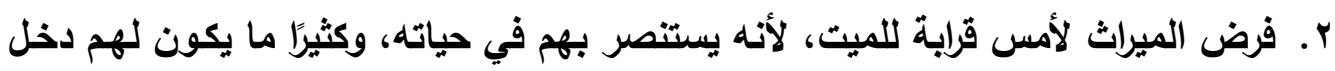
في تكوين r. ثروته، فكان الغتم بالغرم. حدد لكل وارث نصيبًا معينًا، فحسم بهذا مـادة النزاع التي تزرع الأحقاد، وتقطع الأرحام. ؛. كان نصيب الأنثى نصف نصيب الرجل، في بعض الأحيان، لأنه الكافل لأسرته، وعليه وحده ه. يقع عبء الإنفاق. ألحقت الزوجية بالقرابـة تقديسًا للصلة بين الزوجين، وإبرازًا لمظهر الوفاء.

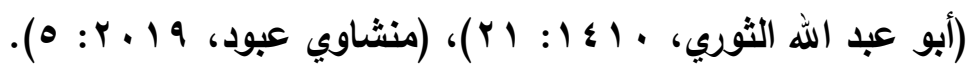

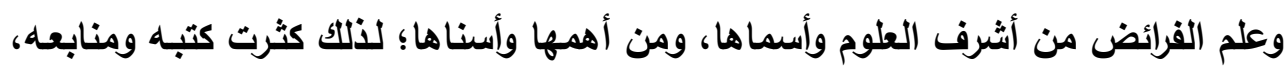

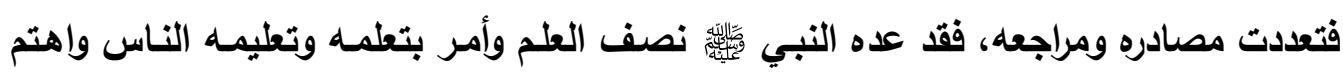

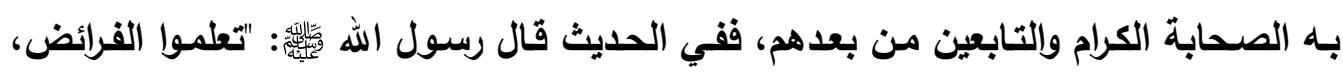
وعلموها الناس، فإني امرؤ مقبوض، وإن العلم سيقبض، وتظهر الفتن، حتى يختلف اثنان في الفريضة فلا يجدان من يقضي بينهما" (رواه الإمام أحمد، والترمذي، والنسائي، والحاكم).

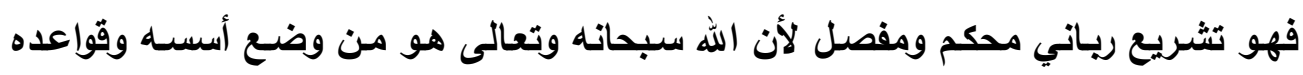

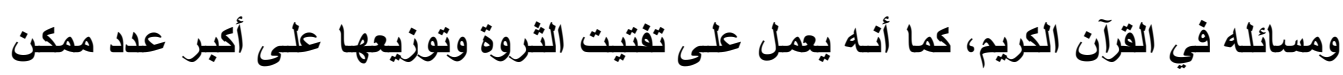

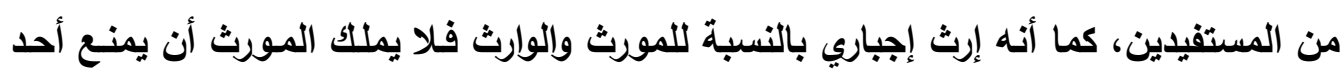

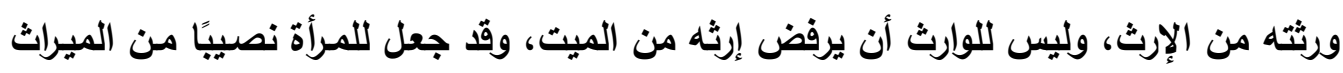
يضمن لها حياة كريمة.

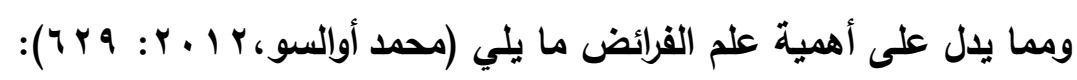

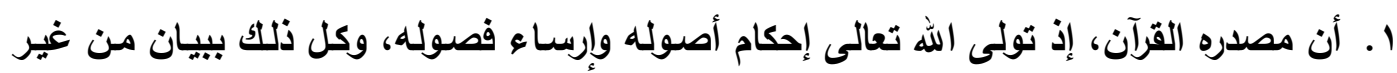
إجمال في نصوص قطعية بلا احتمال.

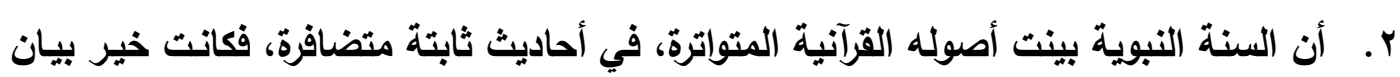
لما أسسه القرآن. 
r. بأت الكتابة في الفرائض(الميراث) في عهد الصحابة الكرام، فلزيل بن ثابت فيه كتاب بالعلم

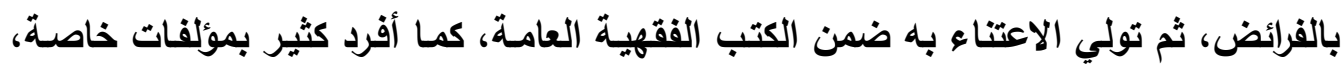
فيها المنظوم وفيها المنثور. مما سبق يتضح أن الله تعالى تكفل ببيان أركان علم الفرائض وأسسـه ومعظم أحكامـه في القرآن، فلم يكلها إلى ملك مقرب ولا نبي مرسل بل قسمها أبين قسم ووضـح أحكامها أتم

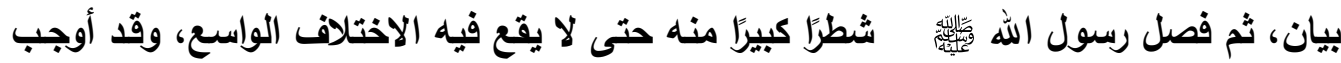
الإسلام على الأمة على سبيل الكفاية تعلمه وتعليمه. ورغم أهمية علم الفرائض وفضله إلا أن واقع تدريسه في التعليم الأزهري يشويـه صعويات

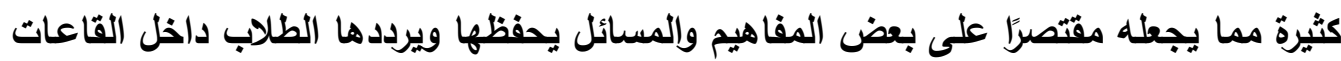
لا تتعداها إلى خارجها، رغم أهميته وإحتياج الناس له في واقع حياتهم. وقد أظهرت نتائج الدراسـات والبحوث السـابقة التي أجريت في مجال علم الفرائض بعض الصعويات التي تواجه تدريسه وأكدت أن واقع تدريسـه يتطلب تطويرًا للطرق المستخدمة في

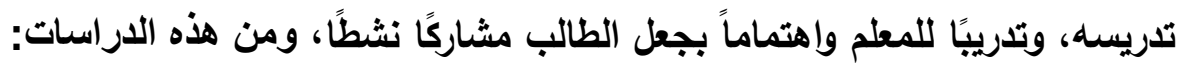

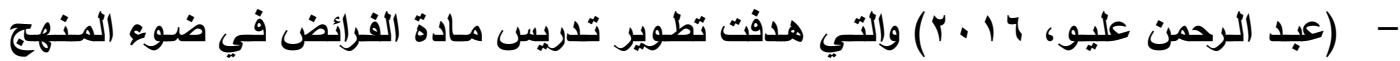
التكاملي بين مادتي الفرائض والرياضيات وإحتياجات المتعلمين.

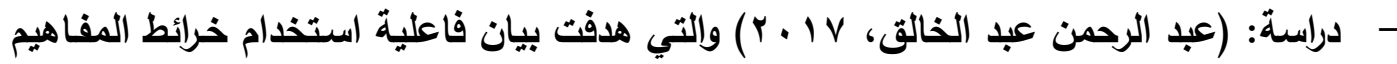
على تحصيل تلاميذ الصف الثالث الإعدادي الأزهري لمفاهيم أحكام المواريث واتجاهاتهم نحو هولئ دراستها. ومسن الأهـافـ التعليميـة التـي تحـرص عليهـا كليـات الثــريعة والقـانون تخـريج علمـاء

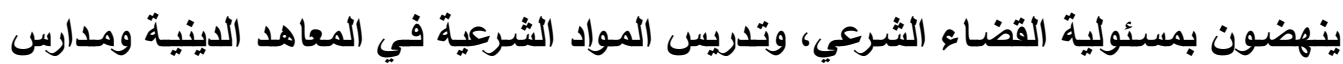

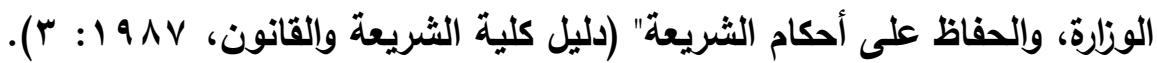
ونصت لائحة كليات الشريعة وإلشريعة والقانون على تدريس الأحوال الشخصية "(لفرائض" لمنسوييها من كليات الثريعة والثريعة والقانون كمادة أساسية وذلكك لأهميتها للخريج (دليل

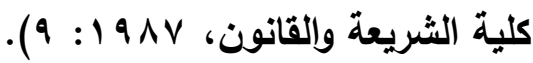
ويدرس الطلاب في هذه المادة مفاهيم متعددة تعد أسساس هذا العلم ويتوقف عليها فهمهـ؛ ومن هذه المفاهيم: (المستحقون للتركة، أصحاب الفروض، العصبات، الحجب، العول، الرد، 
الوصية الواجبة....) كل هذه المفاهيم وغيرها بحاجة إلى معرفة معناها وأقسـامها وخصائصها وهي أساسية ليطبق الدراس الحجب والرد والعول على المسائل التي تتطلب ذلك.

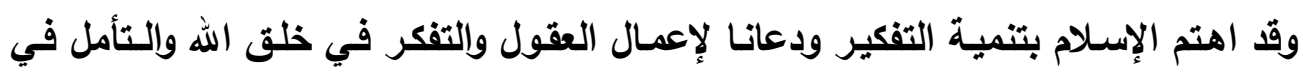

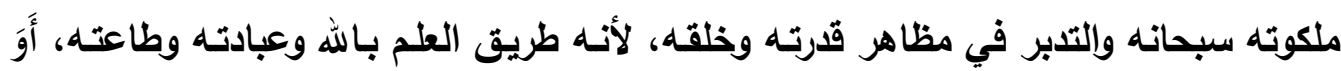

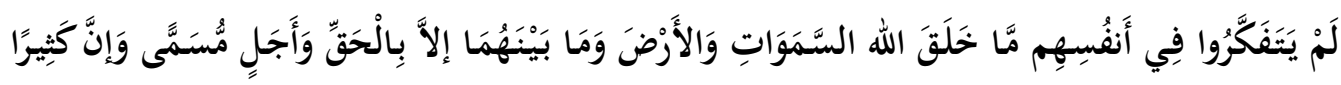

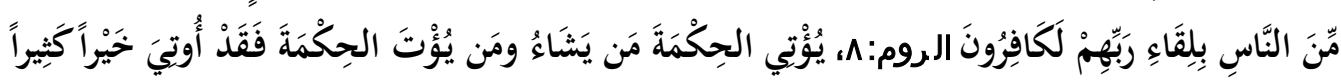

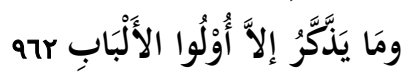

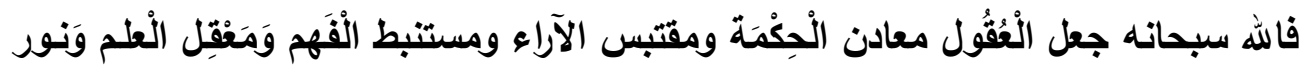

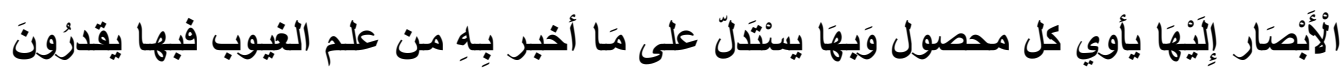

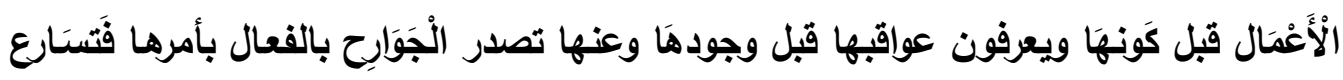

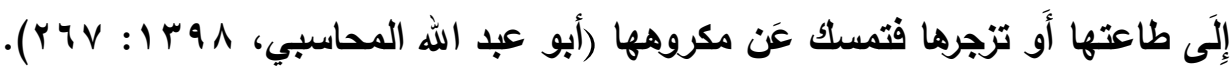

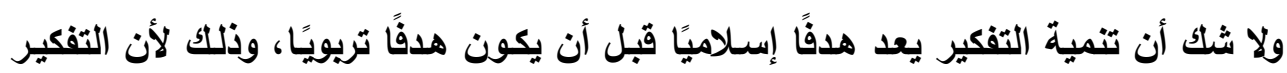

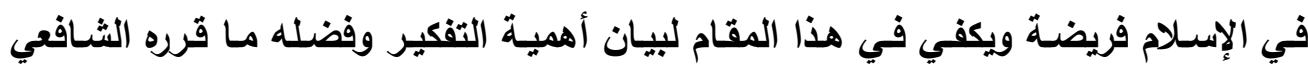

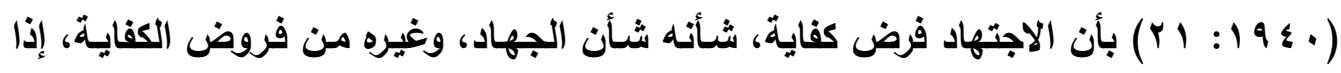

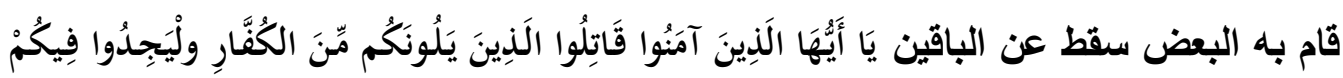

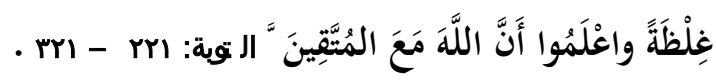
ويمكن استنتاج أن الاجتهاد إذا كان فرض كفاية في حق عامة المسلمين، فإنه فرض عين المين

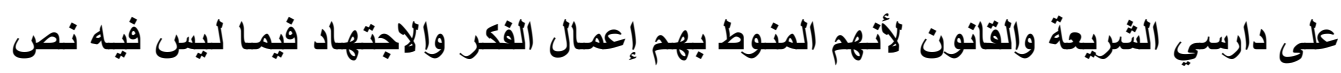
بما لا يخالف الشرع لبيان ما غمض على الناس. ورغم أهمية مفاهيم علم الفرائض والجاتب النظري منـه والذي يتمثل في المفاهيم الرئيسـة

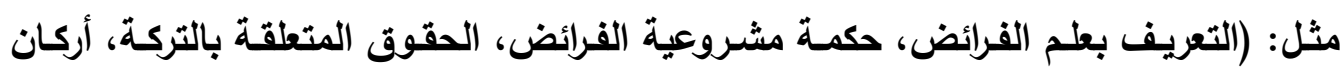

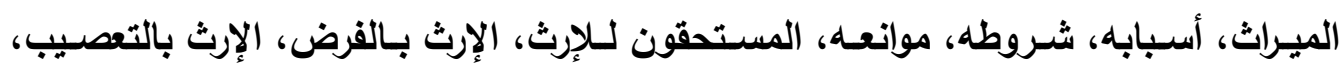

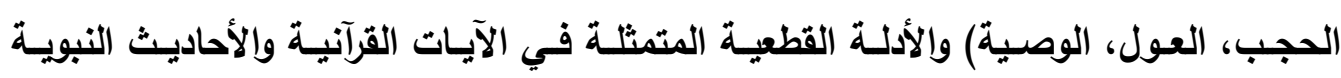

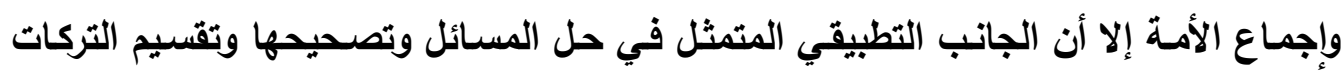

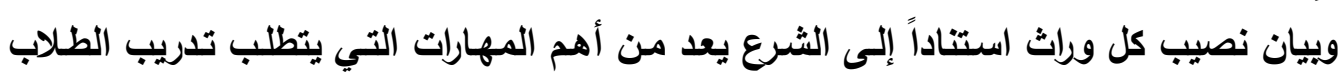


ويعد التفكير الرياضي من أنواع التفكير المهمة التي يحتاج إليها الطالب في دراسته لعلم

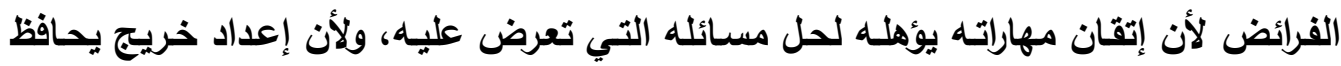

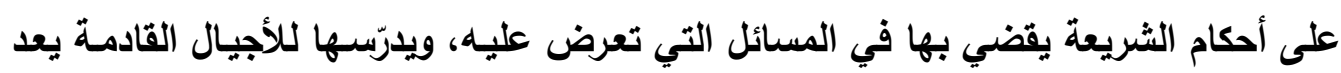

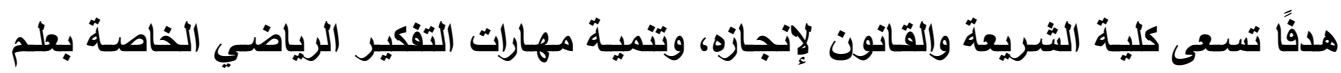

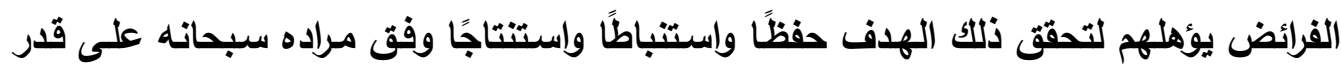
طاقتهم البشرية.

ولأن تطبيق مسـائل علم الفرائض لا يتوقف عند حفظ مفاهيمـه الأساسية وفهمها وإنمـا

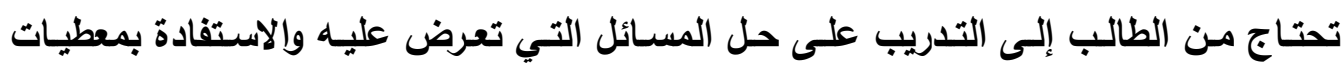

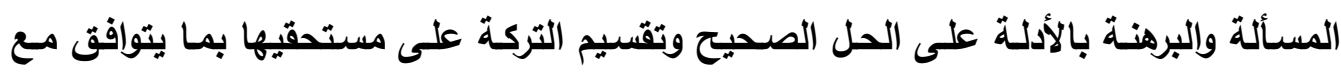

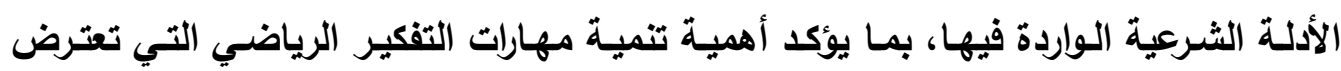
الطالب عند حل مسائله. وتعد مهـارات الاستقراء، والاستتنتاج، البرهـان الرياضـي ضـرورية لـدارس علـم الفرائض تطبيقًا لما يدرسه من مفاهيم ومعلومات نظرية، ويمكن توضيح ذلك من خـلال المثال التالي:

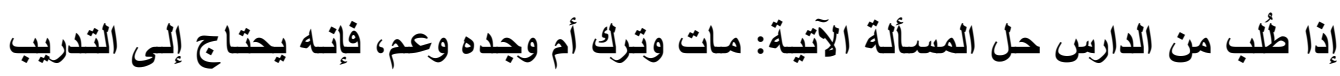

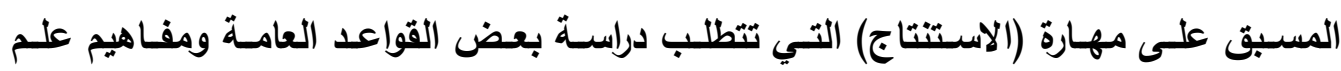
الفرائض مثل الحجب وهو منع مستحق الإرث من الإرث كله أو بعضه ويعرف أقسام الحجب دهب دهب

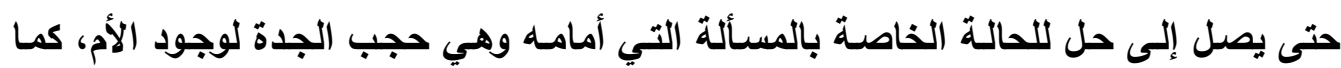
يحتاج للتدريب على مهارة (البرهان الرياضي) التي تجعله يعلل لطله ويبرهن عليه بأدلة نقلية

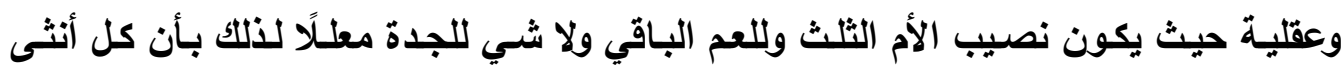

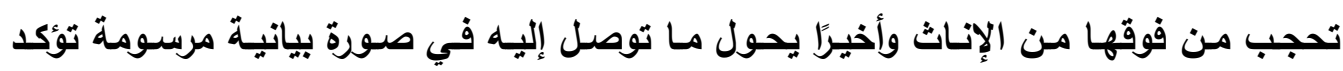
فهمه(مهارة النمذجة). ويمكن تعريف التفكير الرياضي بأنه التفكير الذي يتم بواسطته حل المشكلات الرياضية

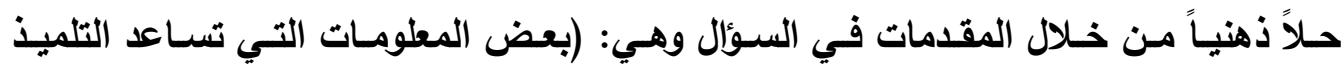

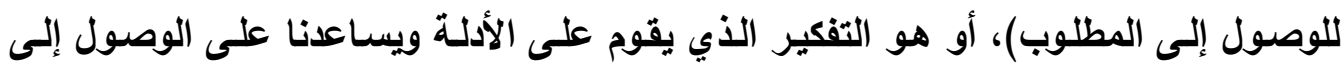

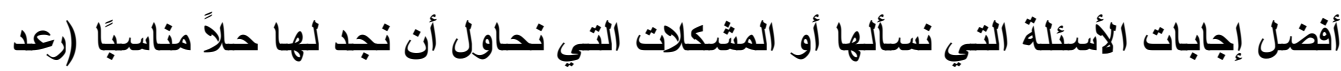

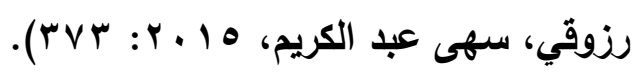


وياستقراء عدد من الاراسات السابقة في مجال تنمية مهارات التفكير الرياضسي منها دراسـة

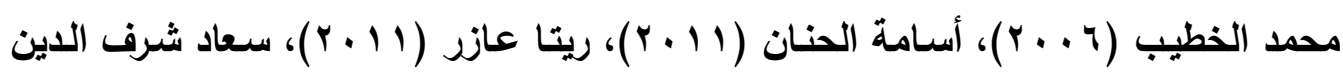

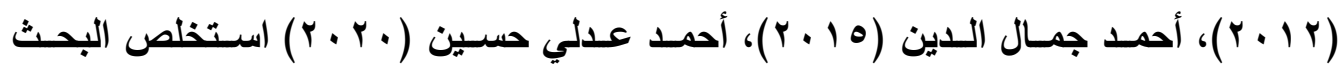
الحالي بعض مهاراته؛ والتي تتمثل في:

1- الاستقراء: الوصول إلى نتيجة عامة اعتماداً على حالات خاصة.

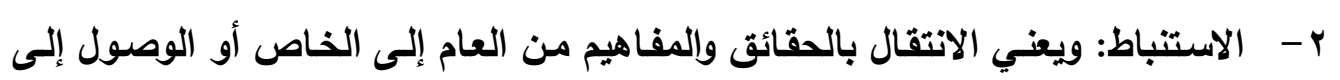

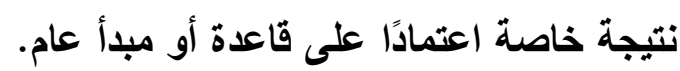
r- - التعبير بالرموز : ويعني استخدام الرموز للتعبير عن الأفكار الرياضية أو المعطيات اللفظية. ـ - حل المشكلة الرياضية: التوصل إلى حل سليم للموقف المشكل الذي يطلب من الطالب حله. ه - التفكير المنطقي: قدرة عقلية تمكن الفرد من الانتقال المقصود من المعلوم إلى غير المعلوم. צ- البرهان الرياضي: الاليل أو الحجة لبيان صحة عبارة تتتج من صحة عبارات سـابقة، وهو المعيار الذي يتخذه الرياضيون لقبول صحة قضية معينة. -V 1 - النمذجة: النموذج الرياضي يعني تمثيلاً رياضيًا للعناصر والعلاقات. 9- التعليل: ويعني التفسير وذكر الأسباب بالإضافة إلى المقارنة بين الثبه والاختلاف.

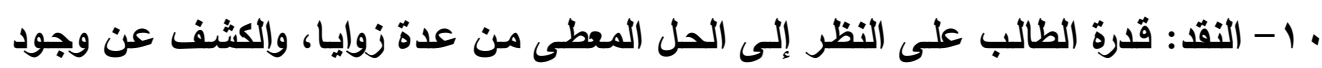
الخطأ في الحل والحل بطريقة أخرى أسهل وأوضح. 1 ا - التبؤ: القدرة على قراءة البيانات أو المعلومات المتوفرة في المشكلة أو الموقف. r ا ا التعميم: صياغة عبارة اعتمادًا على أمثلة أو حالات خاصة. r ا - الاستتتاج: وصول الطالب إلى نتيجة خاصة اعتمادًا على مبدأ أو قاعدة عامة عادة.

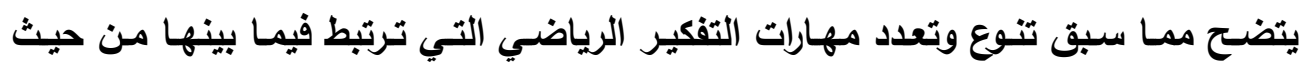
الاستفادة بالمقدمات للوصول إلى نتائج معينة باستخدام التعليل والبرهنة. 


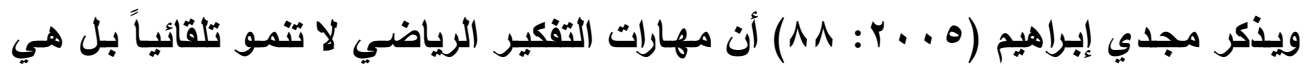

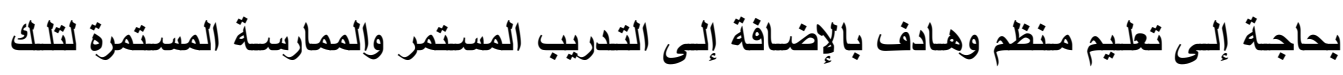

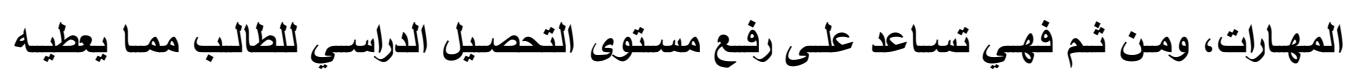

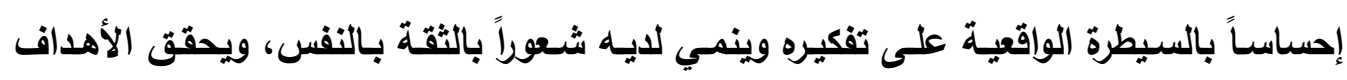
التعليمية.

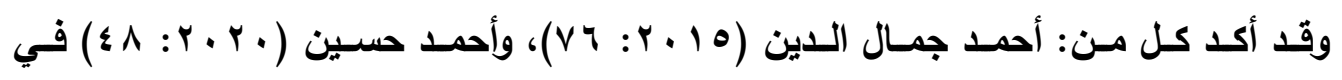
دراستهما على أهمية تنمية التفكير الرياضي للأسباب الآتية:

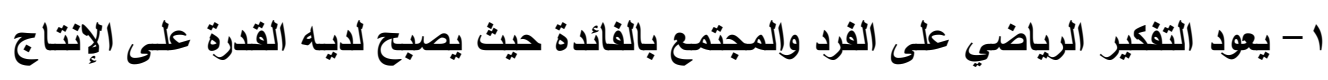
مما يعمل على خدمة مجتمعه. r ب يتيح روئية الأثياء بثكل أوضح وأوسع وحل المشكلات بشكل أفضل. ب - بتيح الفرصة للتفكير الإيجابي وتحويل الطلاب إلى مفكرين منطقيين.

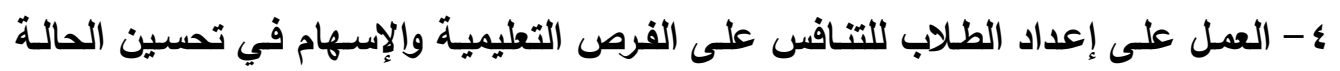
النفسية لايهم واكتساب المعرفة الجديدة.

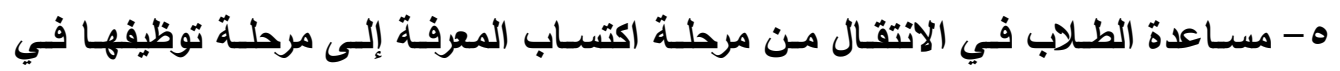

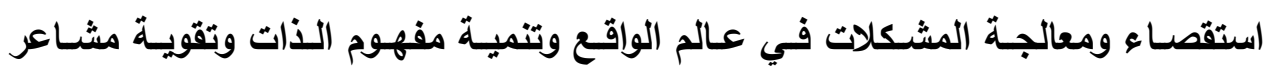
الانتماء والاحساس بالمسؤولية نحو المجتمع.

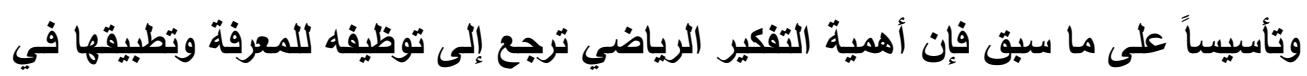

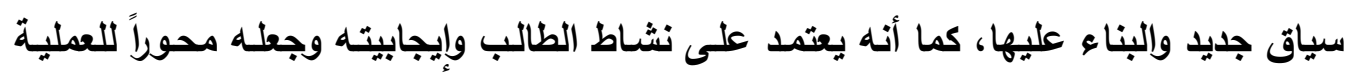
التعليمية يتطلم ويفكر ويطبق المعرفة ويستقرئ ويستتنج ويفرض الفروض ويدرك العلاقات ويبني النماذج ويبرهن ويطلل على حل مشكلة ما.

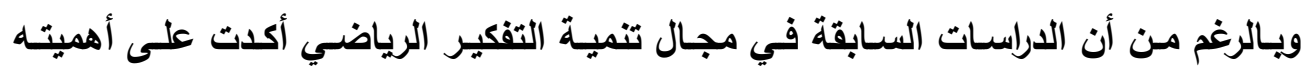
ونفعه للطالب والمجتمع، إلا أنه تبين من استقراء الدراسـات التي تهدف إلى الـى تنمية التفكير

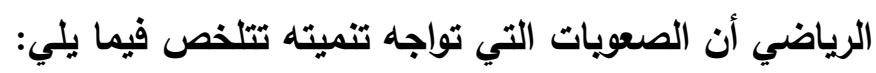
1- مستوى التفكير الرياضي لاى الطلاب أقل من المستوى المقبول تريويًا (محمد الخطيب، تلفياض

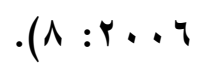


r - وجود اتجاهات سلبية من قبل التلاميذ نحو مـادة الرياضيات نتيجة لشعورهم بجمودها

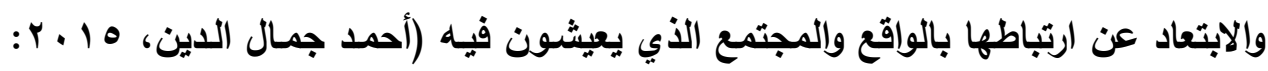

r- التلقين وحفظ القوانين هما الأسلوب المستخدم في تلديس الرياضيات (عبده عبد

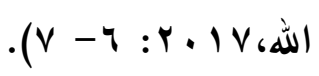

ولا شكك أن الجاتب التطبيقي الأي يتطلبه علم الفرائض من حل المسائل وييان نصيب كل

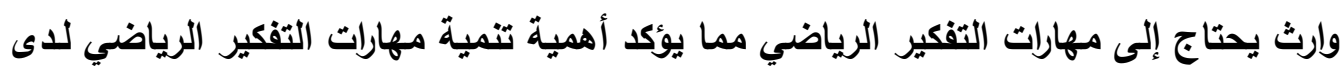

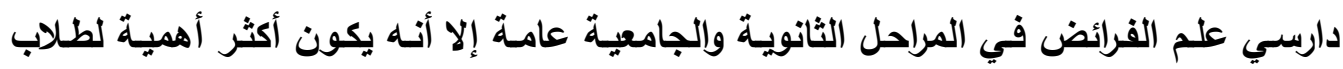

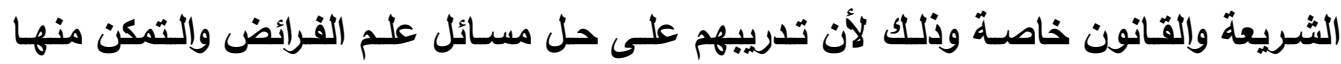

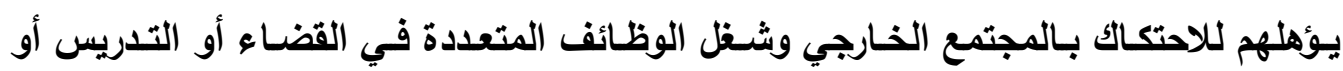
الإقتاء.

ولعلم الفرائض طبيعة خاصة تميزه عن غيره من العلوم؛ إذ يتضمن جانبين: الأول نظري؛

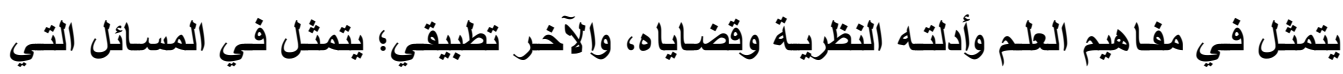

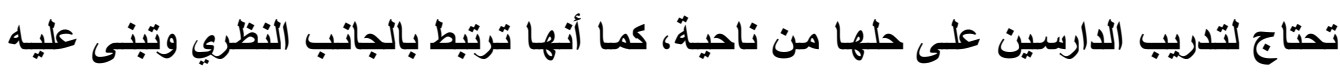

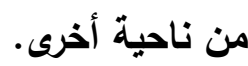
وتعد مفاهيم علم الفرائض معروفة لطالبات الشريعة والقانون فقد سبق لهن دراستها في

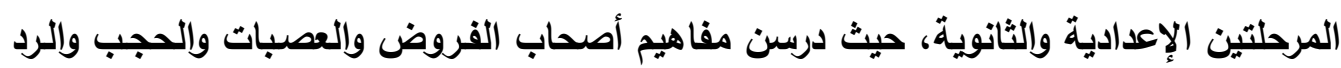
والعول والوصية الواجبة وإلكلالة وغيرها، وتعرضن لاراسة عدد من مسائله إلا أنها في نظرهن

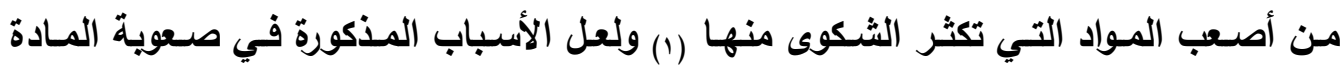

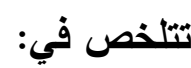
1 - كبر حجم الكتاب المقرر وكثرة الحشو الوارد في المسائل والآراء واختلافات المذاهب في حل المسائل المختلفة، مما يضطر عضو هيئة التدريس إلى تخصيص أجزاء من الكتاب لقرايتها دون شرح أو توضيح من جانبه. r - طريقة التدريس المستخدمة في شرح المادة هي طريقة المحاضرة التي تعتمد على الشرح

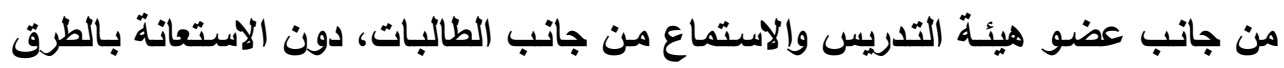


والاستراتيجيات التي تعتمد على نشـاط الطالبات ويحثهن وجهدهن من ناحية؛ واستخدام التكنولوجيا الحديثة في البحث عن المعلومات من ناحية أخرى. ب- صعوية تواصل الطالبات مـع عضو هيئة التدريس بالاستفسار عن بعض المعلومـات أو

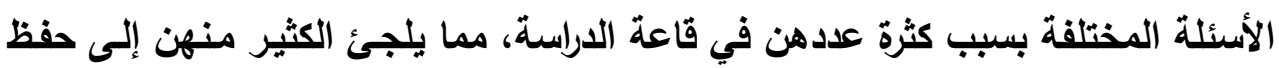
المفاهيم والمسائل دون فهمها. ـ - الامتحانـات التي تعتمد على قياس الحفظ لمـا تم دراسته من مفاهيم وقضايا العلم ممـا يجعل عملية التفكير في حل مسائله صعبة بسبب عدم التدريب عليها خلال فترة الدراسة.

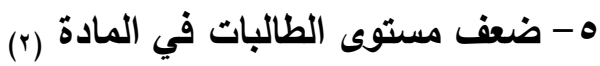
هذا وقد أثارت العديد من الدراسات إلى ضعف مستوى الطلاب في مـادة الفرائض والحاجة

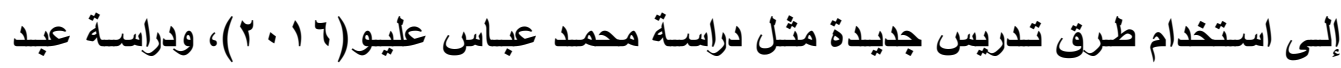

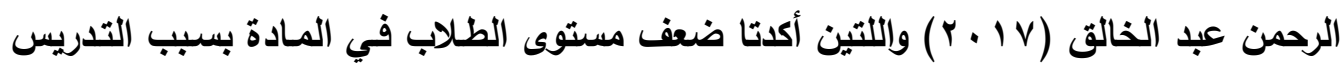
بالطريقة القديمـة، وعدم تـريب الطلاب على حل مسـائل الفرائض بأنفسـهم، وضعف الأداء

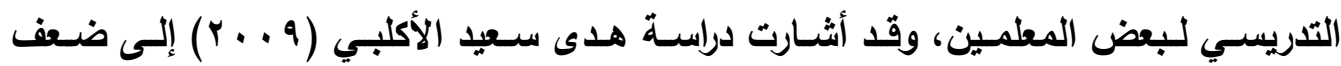

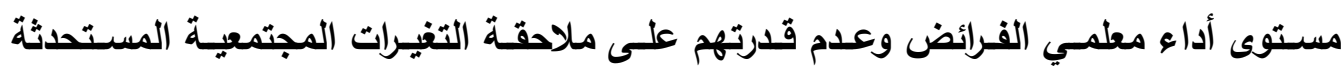
والتكيف معها، والاعتمـاد على الكتاب المقرر وعدم إفساح المجال لغيره من المصادر، ولأن

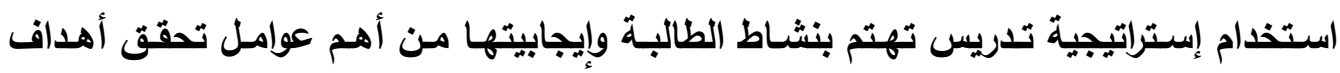
المنهج، استخدم البحث الحالي إستراتيجية دائرة التعلم المدعومـة بالأنشطة الإثرائية التقنية

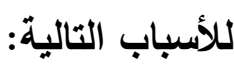
1. اعتمادهـا على النظريـة البنائية المعرفية في مجـال التدريس التي تمتاز بمراعـاة قدرات الطالبـات العقليـة، وتسـاعدهن على التفكير وتثــعهن على التعاون والعمـل الجمـاعيا

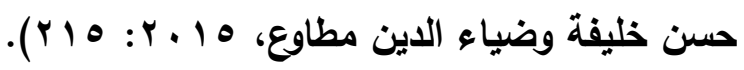

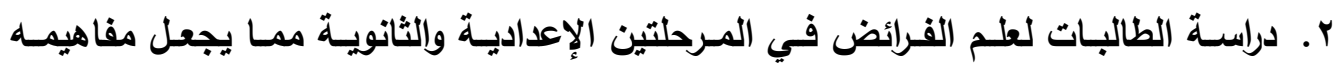
مألوفة لديهن وتكونت للايهن بُنى معرفيـة خاصـة بمفـاهيم علم الفرائض ومسـائله وهذا

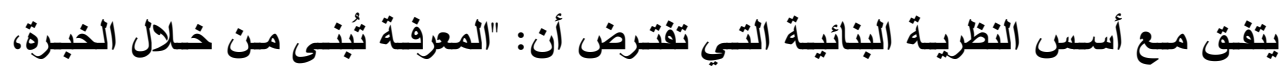


ويالتالي فإن التعلم عملية بنائية يتم فيها بناء عرض داخلي للمعرفة لدى الطالبات"(أحمد

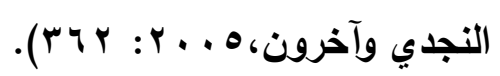

r. مناسبة النظرية البنائية لطبيعة مـادة الفرائض التي تعتمد على الخبرة السـابقة للطالبات وتبني عليها من ناحية؛ كما أنها تتعرض لقضهايا معاصرة خاصـة بالفرائض ممـا تعايشـه الطالبة في مجتمعها من حالات المواريث التي تقسم حسب شرع الله من ناحية أخرى ويالتالي يتفق ذلك مع أحد أسس النظرية البنائية الذي ينص على أن: "المعرفة الجديدة

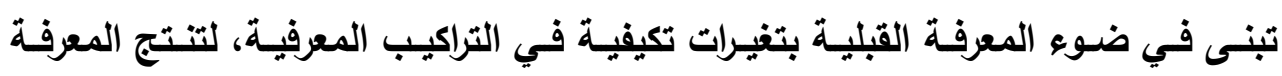

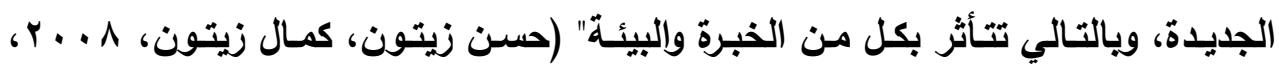

$$
.(10 \cdot-1 \leq 9
$$

ع. مراحل إستراتيجية دائرة التعلم المتمثلة في المراحل التالية: "الاستكشـاف، وتقديم المفهوم،

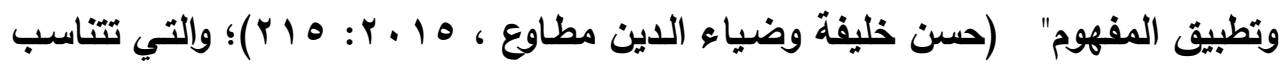

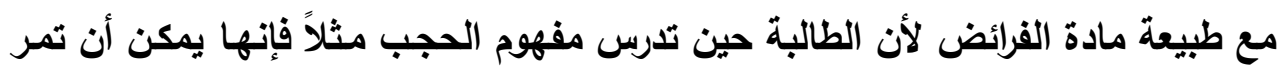

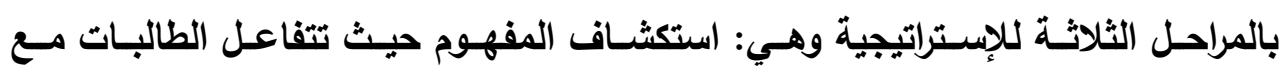
المواقف والأنشطة والخبرات الجديدة التي يعدها عضو هيئة التدريس والتتي تولد لديهن تساؤلات متعددة وتدفعهن للتعاون واستكشاف الأفكار والعلاقات الجديدة وذلك من خلال الاستفادة بخبراتهن السابقة والبناء عليها، ثم مرحلة تقديم المفهوم: حيث يتم تزويدهن

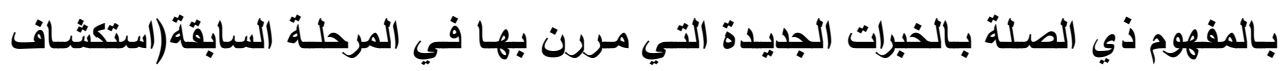

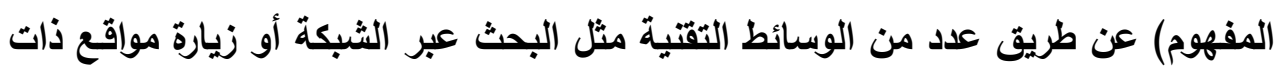
علاقة يحددها عضو هيئة التدريس أو القيام بأنشطة متعددة يعدها عضو هيئة التدريس

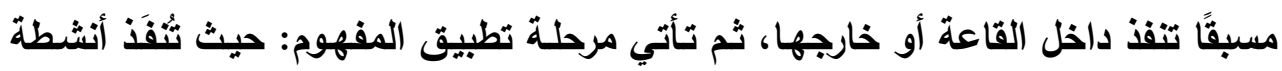

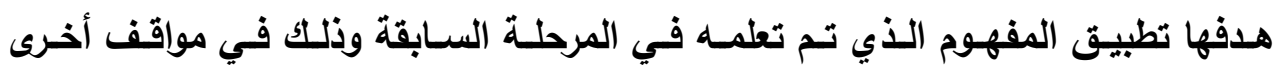

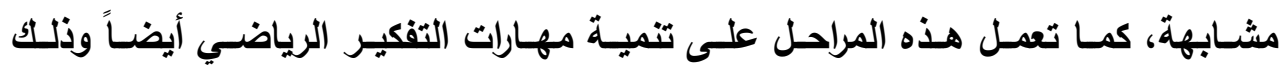
لاعتمادها على نشاط الطالبة وإيجابيتها من حيث استكثاف المفهوم ودراسته والاستفادة

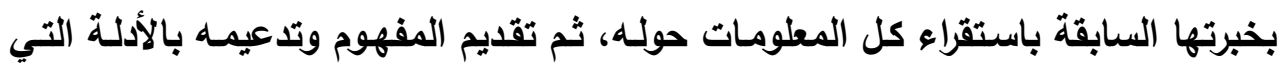
تثبت صحته، ثم تطبيقه في مواقف جديدة، فعلى سبيل المثال: إذا كانت الطالبة بصدد

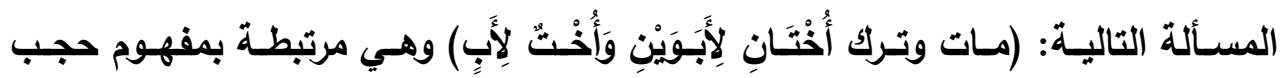


النقصـان، وقـد سـبق لها دراسـته في المرحلـة الثانويـة، فيمكن تنميـة مهـارات التفكير الرياضي من خلال (استقراء) جميع الأدلة الواردة في حجب النقصان ومنها القياس على التى

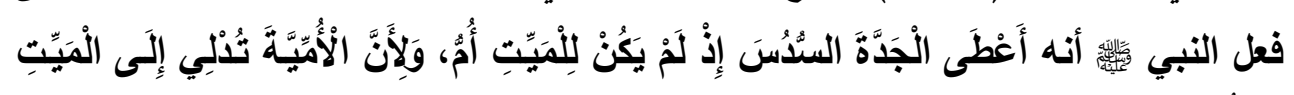

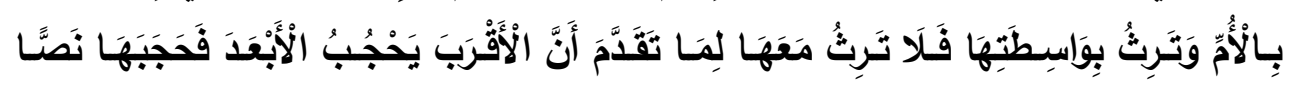

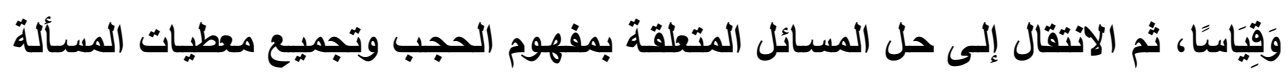
للاستفادة بها في التوصل للمطلوب وصياغة البرهان والحل (مهارة البرهان الرياضي)، ثم تحول الطالبة ما توصلت إليه في صورة بيانية مرسومة تؤكد فهمها (مهارة النمذجة).

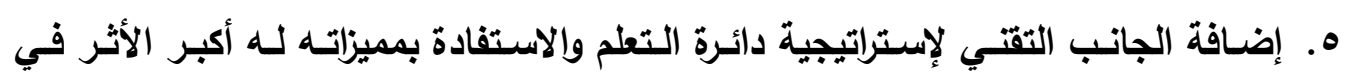

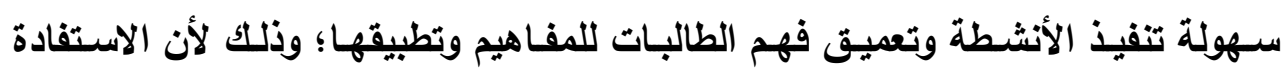

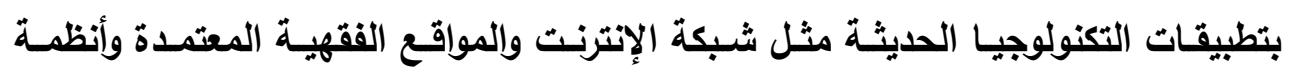
الاتصالات الحديثة التي تتيح التواصل مع الققهاء والوصول لمصادر المعرفة المتعددة التي تجعل المعلومات سهلة المنال خاصة بعد توافر الثبكة لدى أغلب الطالبات واعتمـاد

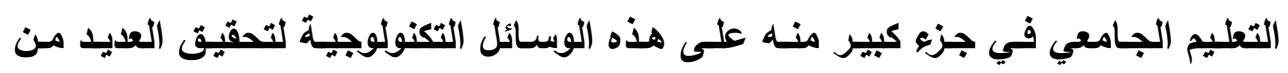

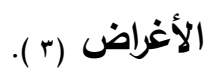

ممـا سبق يمكن القول بأن الحاجـة ماسـة لدراسـة فاعليـة إستراتيجية دائرة التعلم

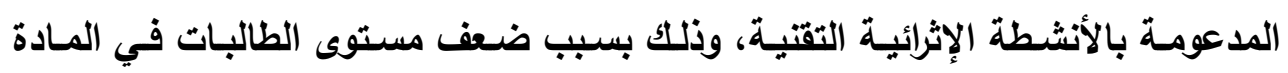

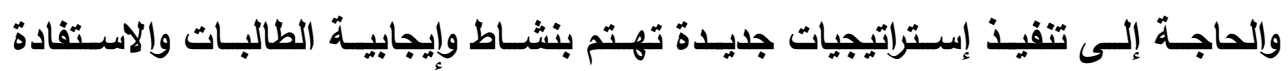
بالتكنولوجيا الحديثة في تنميـة مهارات التفكير الرياضـي للايهن مثل إستراتيجية دائرة

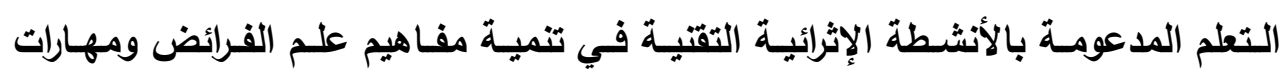
التفكير الرياضي لاى طالبات الثريعة والقانون بجامعة الأزهر .

الإحساسبـالشكلة:

رغم أهمية علم الفرائض لطالبات الشريعة والقانون إلا أنه لا توجد دراسـة سـابقة - على

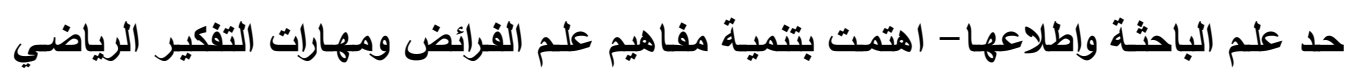

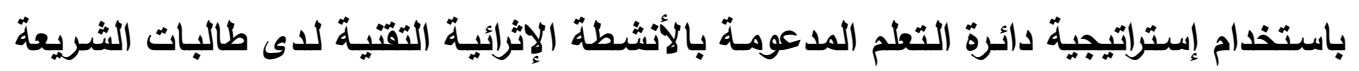


والقـانون بجامعة الأزهر، وترى الباحثة أهمية القيام بهذا البحث للعديد من الأسباب والتي يمكن إيجازها على النحو التالي: 1. ضعف طالبات الثريعة والقانون في مهارات التفكير الرياضي استنادًا إلى النتائج التي

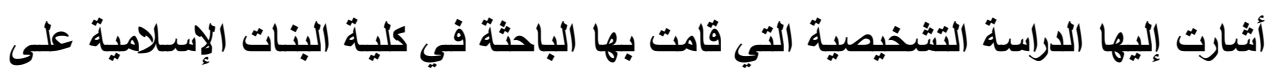

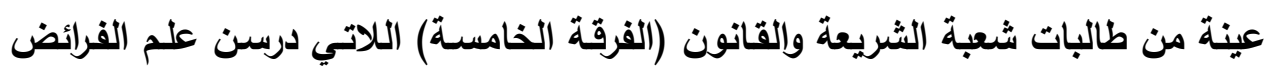

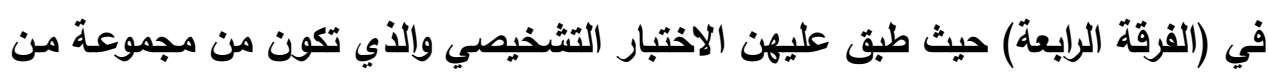

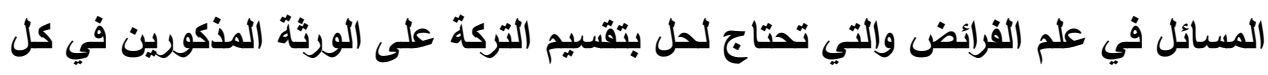

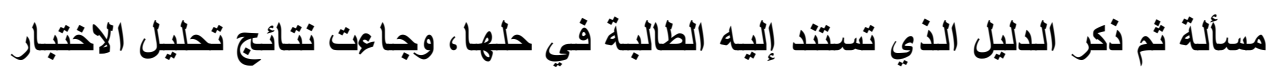

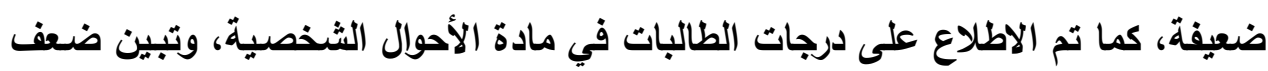
مستوى الطالبات فيها مما يدعم القيام بهذا البحث( أ).

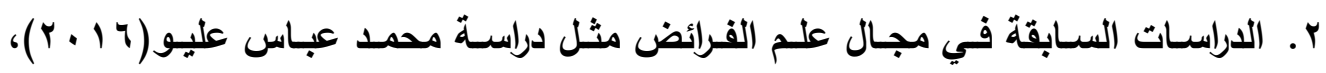

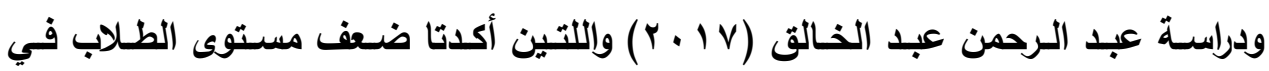
المـادة بسـبب السـلبية وقلـة العنايـة بـالطلاب والاقتصــار على الجانب النظـري وإهمـال

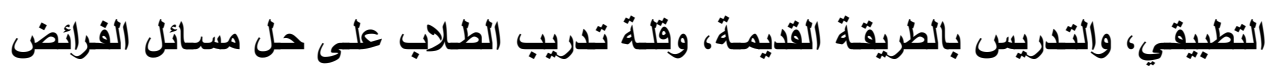

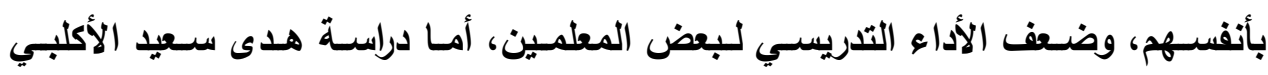

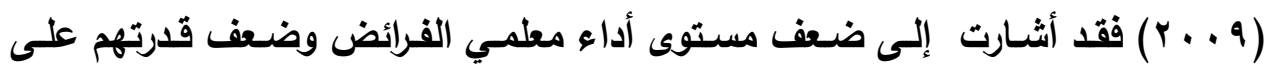
ملاحقـة التغيرات المجتمعيـة المستحدثة والتكيف معها، والاعتمـاد على الكتاب المقرر وندرة إفساح المجال لغيره من المصادر. r. مقابلات أعضاء هيئة تدريس المـادة من ناحيةة؛ والذين أكد بعضهم على تعثر الطلاب في حل مسائل علم الفرائض وحاجتهم إلى التريب المستمر على مهارات حل المشكلات والبرهان الرياضي والاستنتاج وغيرها، ومقابلات طالبات الثريعة والثشريعة والقانون من فئن ناحية أخرى؛ والللاتي ذكرن عدة أسباب في صعوية المادة عليهن وضعف مستواهن فيها وليهاب 
؛. الحاجة إلى تلبية مطالب المجتمع من كوادر دينية مدرية على حل ما يعرض عليها من

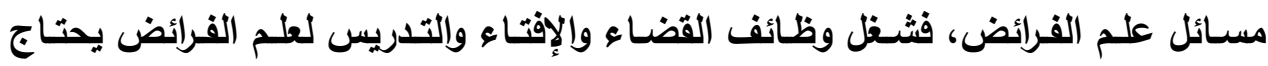

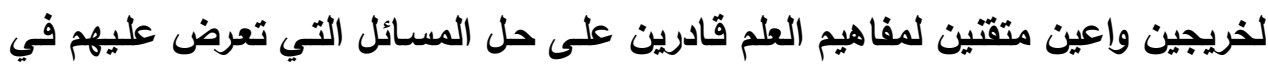

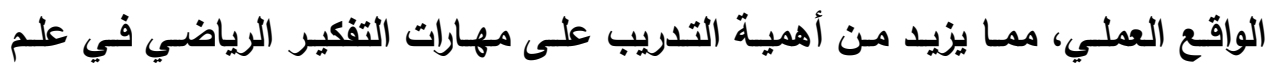
الفرائض.

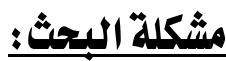

تمثلت مشكلة البحث كما اتضح من مقدمته في ضعف طالبات الثريعة وإلقانون في حل

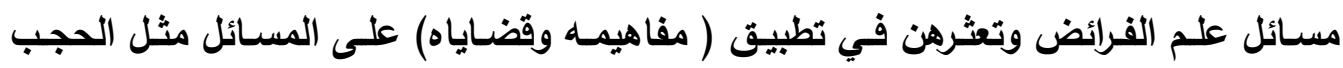
والعول والرد، وحاجتهن إلى تنمية مهارات التفكير الرياضي مثل (الاستقراء - الاستتناج البرهان - النمذجة ) وقد تبين ذلك من نتائج الدراسة الاستطلاعية، وحصر درجات التهات الطالبات

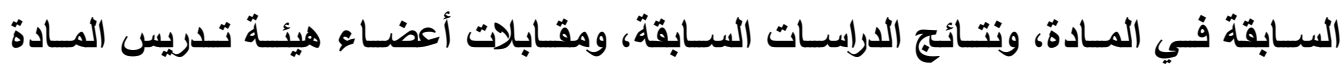
والطالبـات، ويـلكك يمكن صياغة مشكلة البحث في السيوأل الـرئيس التـالي : "مـا فاعليـة

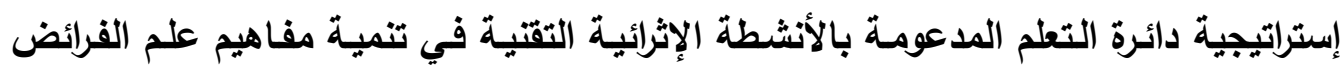
ومهارات التفكير الرياضي لاى طالبات الثريعة والقانون بجامعة الأزهر؟" الإنة وتفرع عنه الأسئلة الفرعية التالية:

1 - ما مفاهيم علم الفرائض اللازم تتميتها لاى طالبات الثريعة والقانون بجامعة الأزهر؟ r - ما مهارات التفكير الرياضي اللازمة لطالبات الثريعة والقانون بجامعة الأزهر من وجهة نظر المتخصصين؟ ץ- ما إستراتيجية دائرة التعلم المدعومة بالأنثطة الإثرائية التقتية في تنمية مفاهيم علم الماني الفرائض ومهارات التفكير الرياضي لاى طالبات الثريعة والقانون بجامعة الأزهر؟

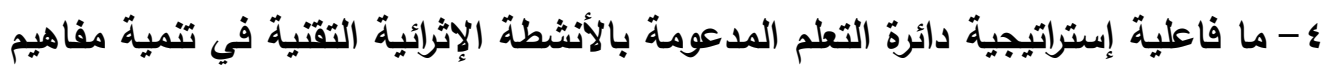
علم الفرائض لاى طالبات الثريعة والقانون بجامعة الأزهر؟ ه - ما فاعلية إستراتيجية دائرة التعلم المدعومة بالأنثطة الإثرائية التقتية في تنمية مهارات التفكير الرياضي في علم القرائض لاى طالبات الثريعة والثقانون بجامعة الأزهر؟ 


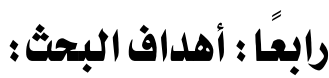

هدف هذا البحث تحقق الأهداف التالية: 1 - وضع أسس إستراتيجية دائرة التعلم المدعومة بالأنثطة الإثرائية التقتية واستخدامها في تدريس مقرر علم الفرائض للطالبات. r - وضع أسس صياغة الأنثطة الإثرائية التقتية في علم الفرائض لاى طالبات الثريعة والقانون بجامعة الأزهر. r- تعرف فاعلية إستراتيجية دائرة التعلم المدعومـة بالأنثطة الإثرائيـة التقتيـة في تنميـة

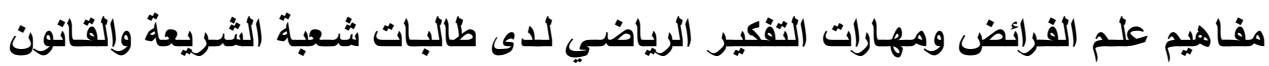

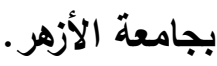

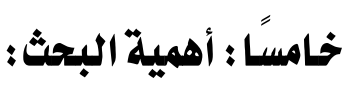
يتوقع أن تستفيد الفئات التالية من هذا البحث، وذلك على النحو التالي:

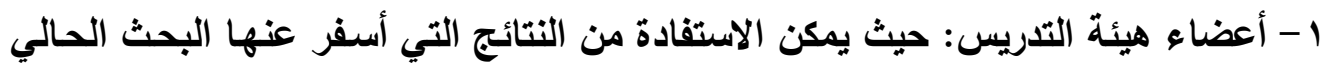

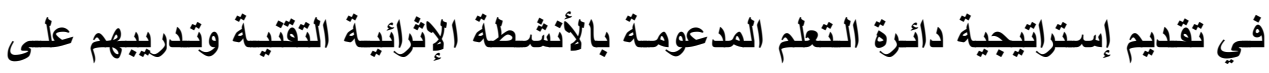
تطبيقها في التدريس الجامعي لطلاب وطالبات الثريعة والقانون. r- طلاب وطالبـات الثريعة والقانون: حيث يمكنهم الاستفادة بالأنثطة الإثرائيـة التقنية

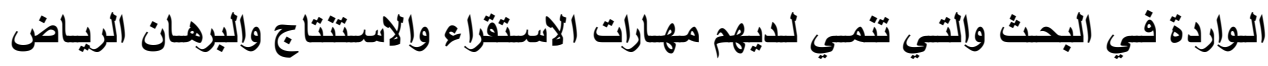
والنمذجة في حل مسائل علم الفرائض. r- مخططو وواضعو المقررات الفقهية: حيث يمكن أن يوفر لهم هذا البحث الإطار النظري

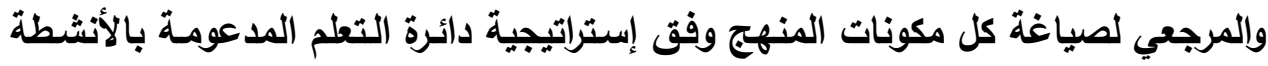

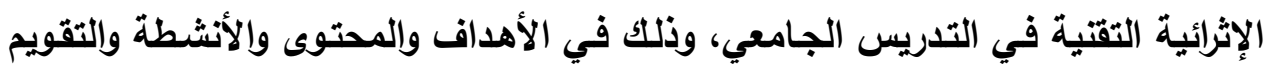
التزيوي. ؛ - الباحثون: حيث يفتح هذا البحث المجال أمسامهم للاهتمام بمهارات التفكير الرياضي وتنميتها باستخدام استراتيجيات ويرامج تدريس متنوعة في مجال علم الفرائض. 


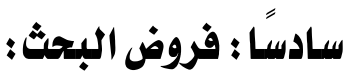

في ضوء أهداف البحث، ومتغيراته أمكن صياغة الفروض التالية: 1 - وجود فرق ذو دلالة إحصائية بين متوسطي درجات طالبات المجموعة التجريبية في التطبيقين القبلي والبعدي لاختبار مفاهيم علم الفرائض لصالح التطبيق البعدي. r-وجود فرق ذو دلالة إحصائية بين متوسطي درجات طالبات المجموعة التجريبية

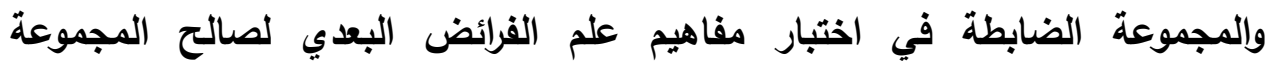
التجريبية. r- وجود فرق ذو دلالة إحصائية بين متوسطي درجات طالبات المجموعة التجريبية في التطبيقين القبلي والبعدي لاختبار مهارات التفكير الرياضي لصالح التطبيق البعدي. ع- وجود فرق ذو دلالة إحصائية بين متوسطي درجات طالبات المجموعة التجريبية

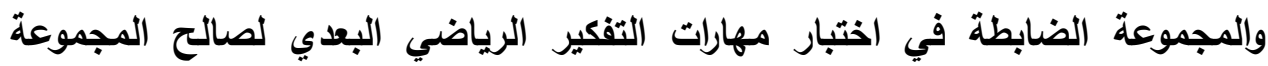

التجريبية.

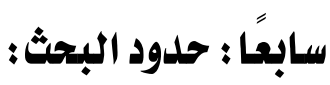

اقتصر هذا البحث على الحدود التالية:

1 - حدود بشرية: مجموعة من طالبات الفرقة الرابعة بشعبة الثريعة والقانون بجامعة الأزهر بأسيوط، تم تقسيمها إلى مجموعتين متكافئتين ضابطة درست بالطريقة المعتادة، تجريبية درست باستخدام إستراتيجية دائرة التعلم المدعومة بالأنشطة الإثرائية التقتية.

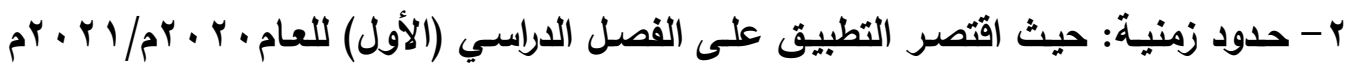
والذي درست فيه طالبات الفرقة الرابعة مقرر الأحوال الثخصية للمسلمين المواريث وفق لائحة برنامج الليسانس في الشريعة والقانون.

r - بدود موضوعية:

• قامت الإستراتيجية على ثثلاث مراحل: (الاكتشاف- تقديم المفهوم - تطبيق المفهوم).

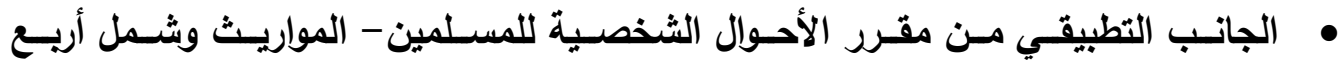
موضوعات رئيسة على النحو التالي: - الإرث بالفرض: (ميراث الفروع، ميراث الأصول، ميراث الزوجين، ميراث الحواثي). - الإرث بالتعصيب: (العاصب بالنفس، والعاصب بالغير). 


$$
\text { - - الحجب: (أنواع الحجب، قواعد حجب الحرمان). }
$$
- الحساب في علم الفرائض: (أصول المسائل، تصحيح المسائل). ع - حدود مكانية: كلية البنات الإسلامية بأسيوط.

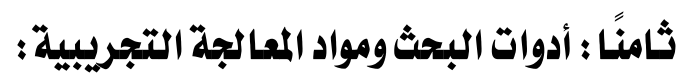
اعتمد البحث على الأدوات ومواد المعالجة التجريبية التالية:

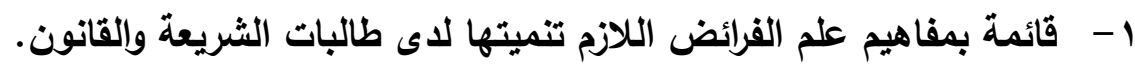
r- بائمة بمهارات التفكير الرياضي اللازمة لطالبات شعبة الثريعة والقانون.

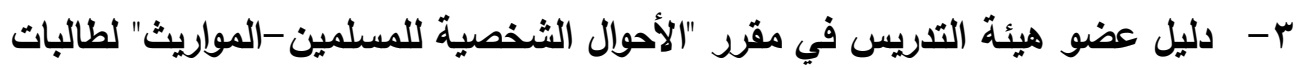
شعبة الثريعة والقانون بالقرقة الرابعة. ع - اختبار مفاهيم علم الفرائض لطالبات شعبة الثريعة والقانون. ه - اختبار مهارات التفكير الرياضي لطالبات شعبة الثريعة والقانون.

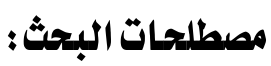

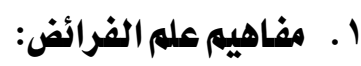

الفرائض: جمع فريضة، فعيلة من الفرض، وهو في اللغة: التقير والقطع، وفي الثرع: ما ثبت بدليل قطعي لا شبهة فيه. وسمي هذا النوع من الفقه "فرائض" لأنه سهام مقدرة ثبت فيته

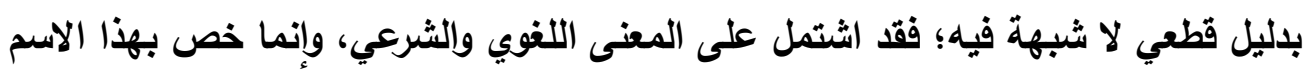

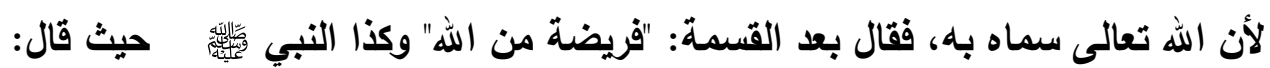

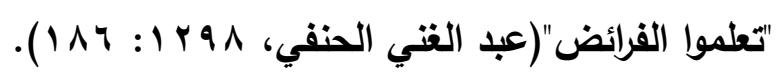

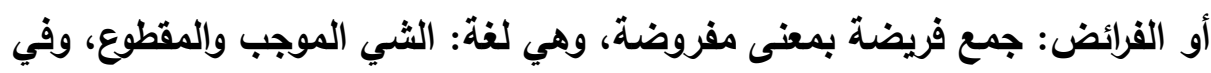

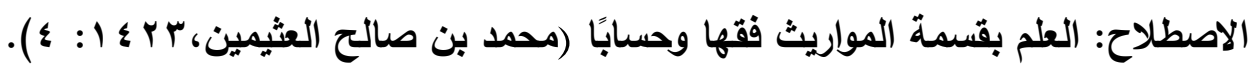
ويقصد بعلم الفرائض في هذا البحث: العلم بقسمة المواريث المقرة على طالبات الثريعة والقانون، وتطبيقها على المسائل ببيان نصيب كل وارث كما بينه الثارع سبحانه. ويقصد بمفاهيم علم الفرائض في هذا البحث: مجموعة من المفاهيم الرئيسة المقررة على لئى طالبات الثريعة والقانون، وتعد الجاتب النظري الذي ينيى عليه الجانب التطبيقي من حل

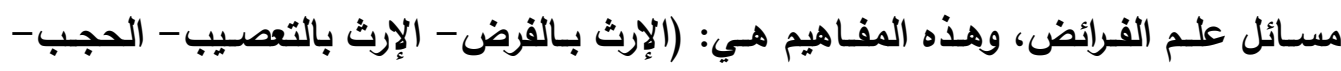


الحساب في علم الفرائض) وتقاس بالدرجة التي تحصل عليها الطالبة في اختبار مفاهيم علم الفرائض من إعداد الباحثة.

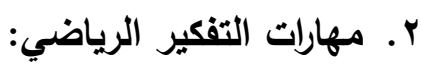
التفكير الرياضي: هو التفكير الأي يمارسه الفرد عند محاولة بيان الأسباب والعلل التي تكمن وراء محاولة معرفة نتائج أعمال الناس ويتضمن محاولـة الحصول على أدلـة تؤيد أو تنفي

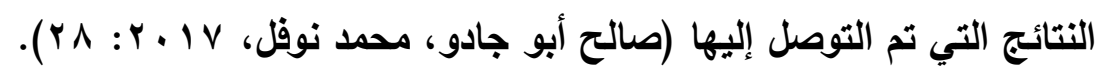
مهاريات التفكير الرياضي: مجموعة من المهارات المطلوب من طالبة الثريعة والقانون إتقانها حتى تتمكن من حل مسائل علم الفرائض، وهذه المهارات هي "الاستقراء - الاستنتاجالبرهـان - النمذجةة" وتقـاس بالدرجة التـي تحصل عليهـا الطالبـة في اختبـار مهارات التفكير الرياضي من إعداد الباحثة.

ويمكن تعريف المهارات إجرائيًا على النحو التالي:

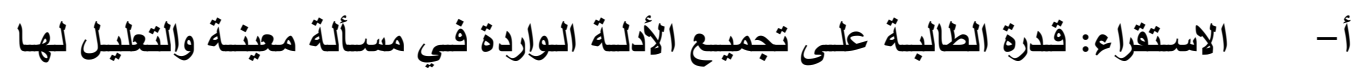
وتجميع الآراء الواردة فيها واستخلاص الرأي الراجح.

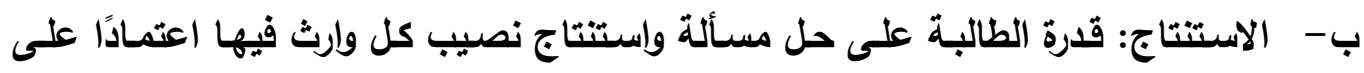

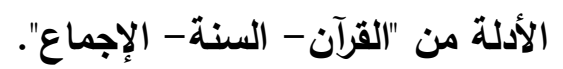
ت- البرهان الرياضي: مجموعة من المهارات الفرعية التي تستدعي تدرب الطالبة عليها حتى الإنى تتمكن من حل مسائل علم الفرائض وتبدأ بالتخطيط ثم البناء ثم التقويم للبرهان، اعتمـادًا على الأدلة والتعليل للبرهان. ث - النمذجة: قدرة الطالبـة على تمثيل بيانـات المسـئل في صورة جداول وتمثيل الحل في صورة أعمدة أو دوائر بيانية.

الإطار النظري 


\section{المحور الأول - مفاهيم علم الفرائض:}

يعد علم الفرائض من المقررات الأساسية التي يلرسيها طلاب وطالبات الثريعة والثريعة والقانون، وقد تتاول العلماء مفهوم الفرائض لغة وشرعًا على النحو التالي:

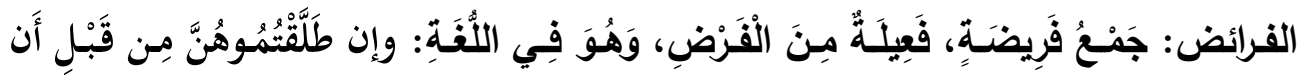

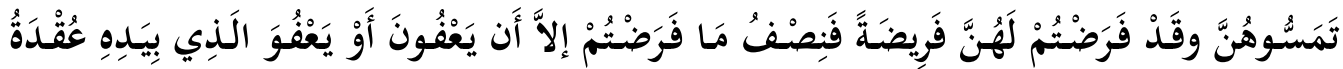

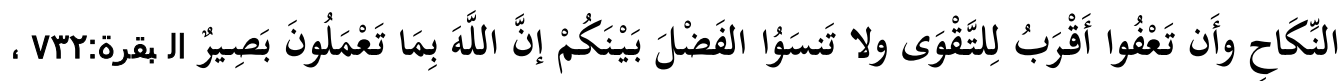

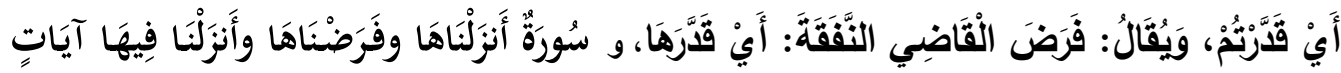

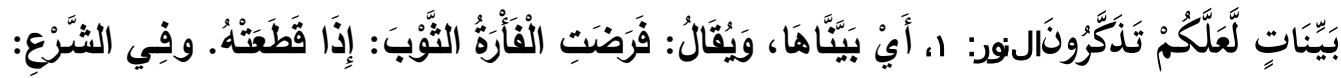

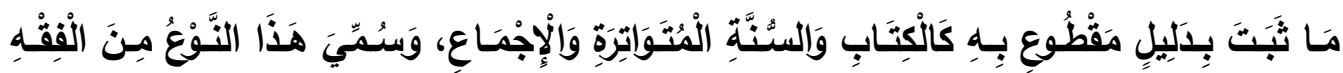

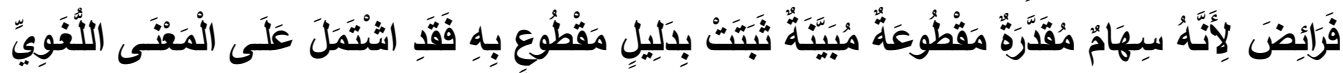

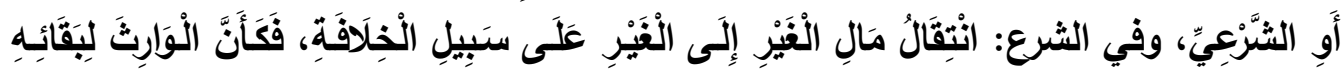

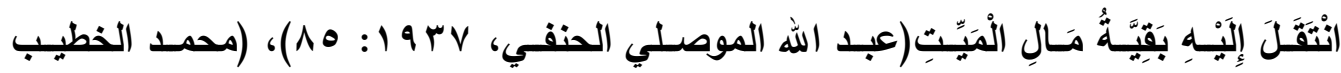

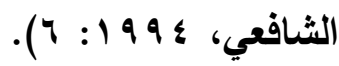

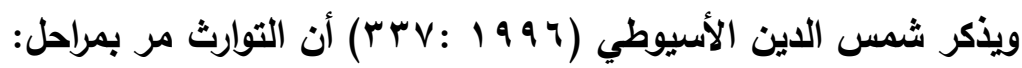

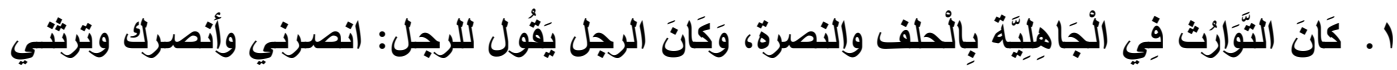

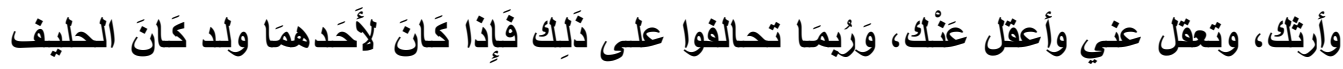
كَأحد أَوْلَاد حليفهـه.

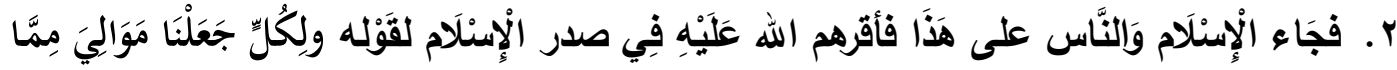

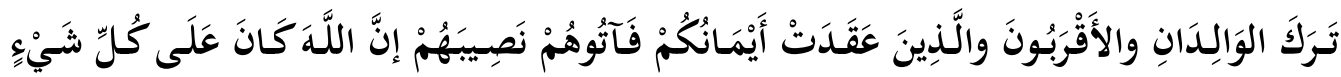

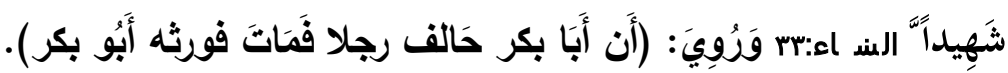

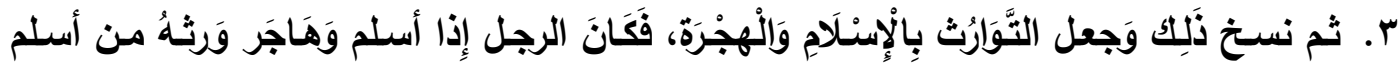

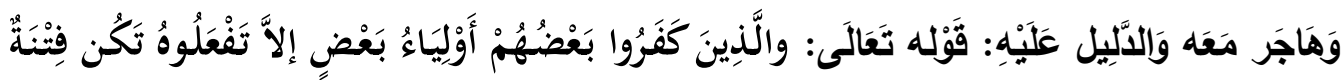

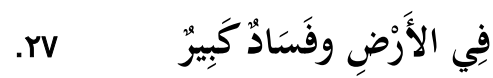

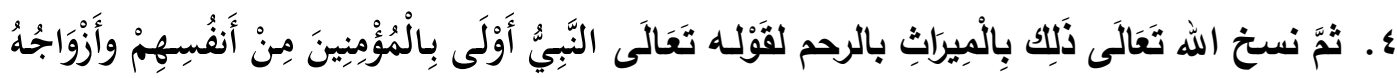

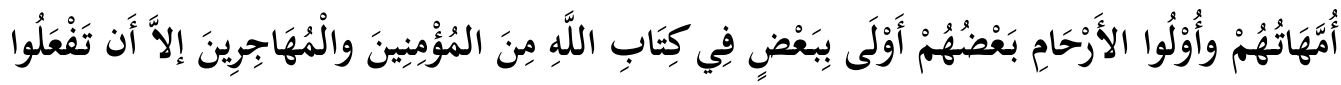




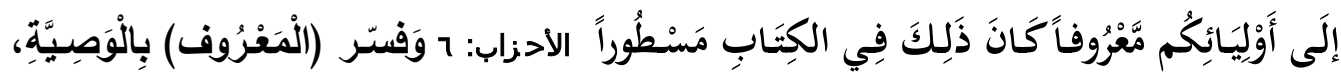

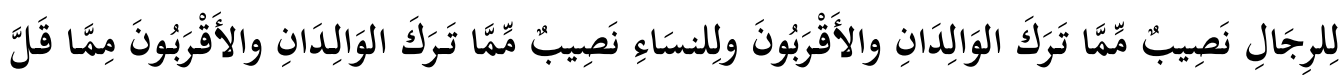

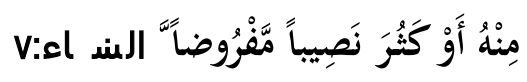

وعلى هذا فإن المقرر في الثريعة الإسلامية هو الميراث بالرحم وعليه الأمة حتى يومنا

هذا، وقد فصل القرآن والسنة والسلف الصالح وأحواله النصيب المقدر لكل وارث. حكمة مشروعية الفرائض:

الثريعة الإسلامية من بين الثرائع التي أخذت بنظام التوريث وأنزل الله له شرعة مفصلة

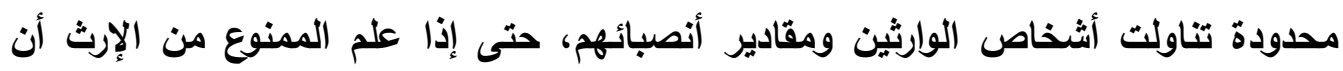
منعه آتٍ من السماء اطمأتت نفسه ورضي حكم الله، أما إذا ترك الأمر في الميراث للناس التها

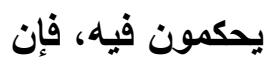
هذا يكون مصدر اضطراب وشقاق. ثم إن الإسلام أزال الغبن الذي كان لاحقا بالمرأة في

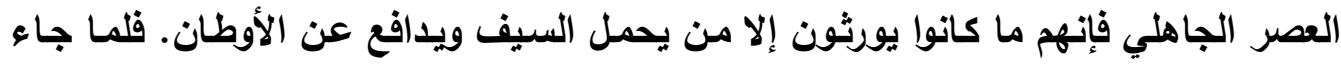

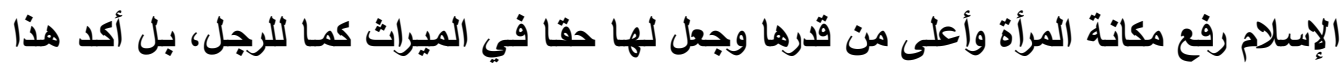

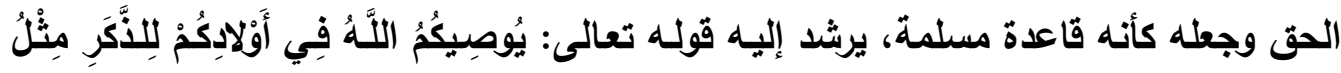

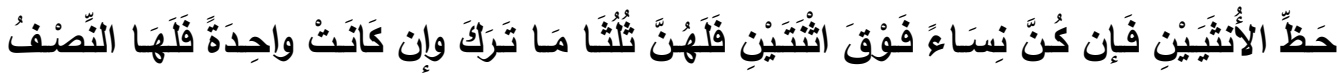

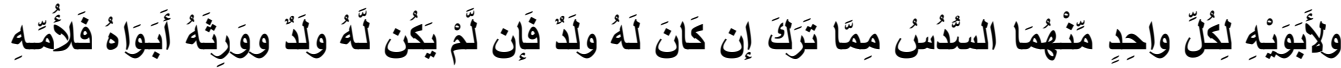

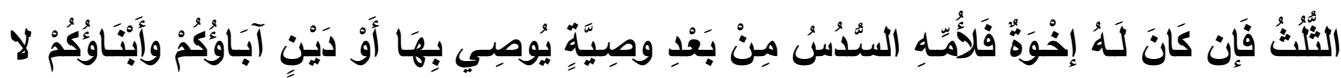

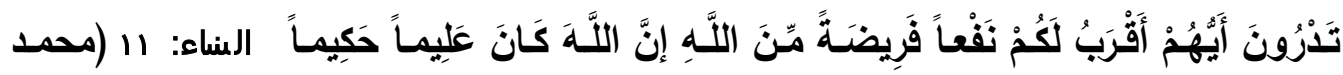

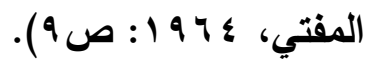

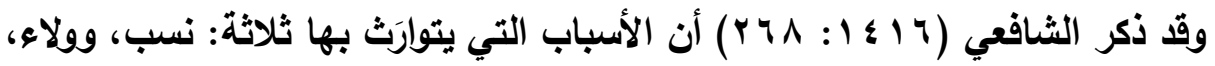
ونكاح

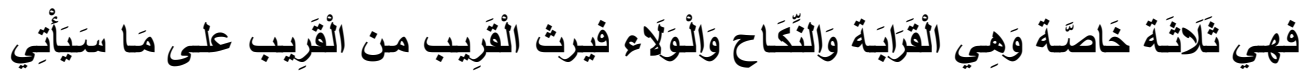

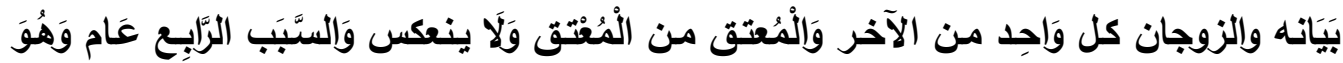

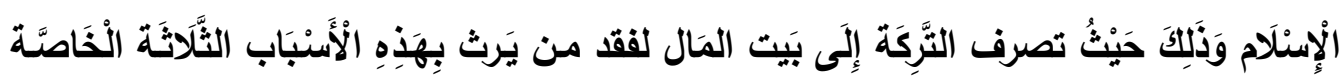

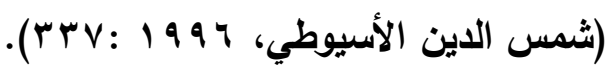


مما سبق تتضح القواعد التي بنى عليها الإسلام أسباب الميراث والتي تتلخص في القرابـة: حيث يرث القريب قريبه، والنكاح: الذي ألحق بالنسب توثيقاً للعلاقة المكرمـة في الإسـلام، الولاء والإسلام، وكل سبب له شروط وقواعد تحكمه يمكن الرجوع إليها في كتب التراث.

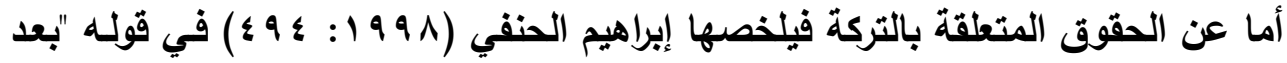

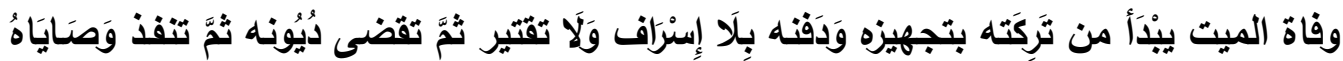

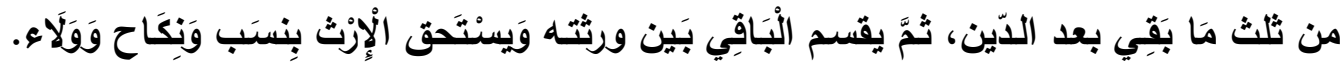

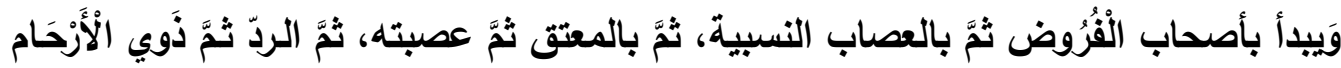

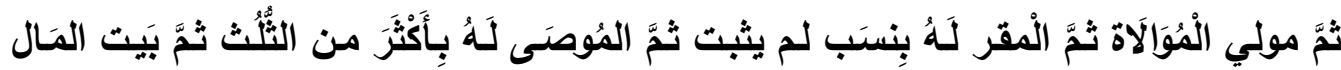

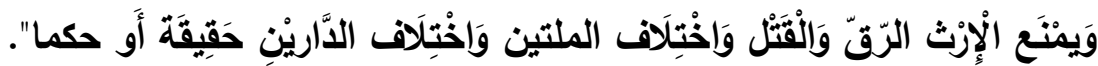
وشروط الإرث ثلاثة:

أـ تحقق مـوت المـورث أو إلحاقـه بـالأموات. مثنال إلحاقـهـه بـالأموات: المفقود إذا مضت مـدة انتظاره. ب . تحقق حياة الوارث بعده أو إلحاقه بالأحياء. مثل إلحاقه بالأحياء: الحمل إذا تحقق وجوده

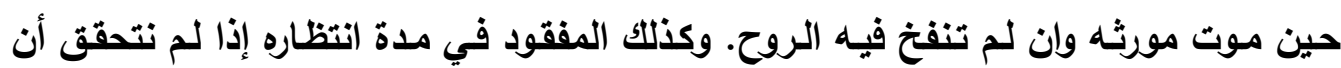
موته قبل موت مورثه، ويناء على هذين الثرطين فلا توارث بين متوارثين ماتا ولم يَعلم أيهما اسبق موتا، مثل ان يموتا بهام أو غرق أو حريق أو حادث طريق ونحوه لعدم تحقق المورث قبل الوارث وحياة الوارث بعده.

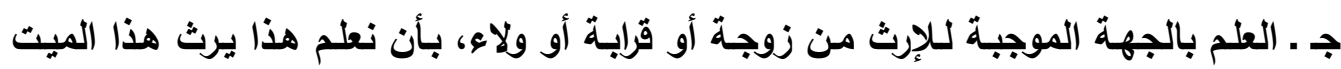

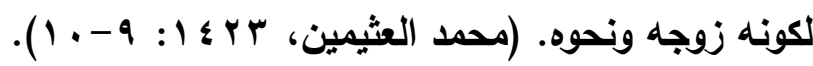

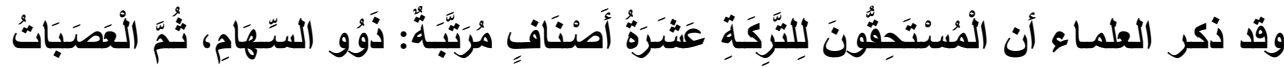

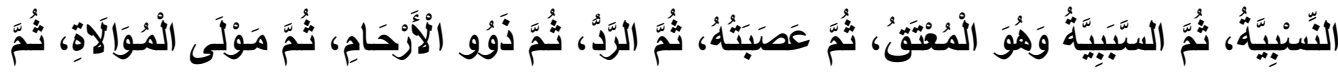

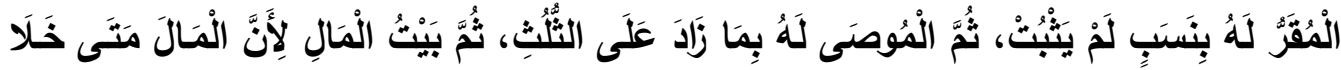

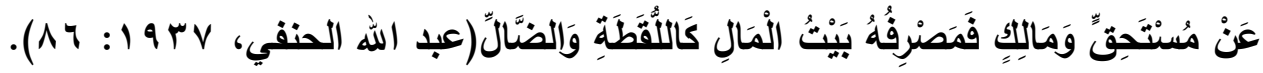

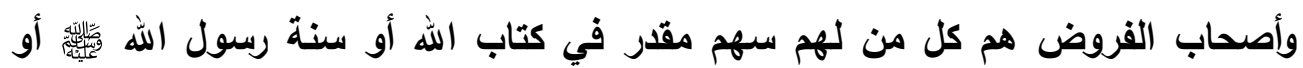
الإجماع، أما العصبات فليس لهم سهم مقدر وإنما يرثون ما بقي من أصحاب الفروض، وإذا 
انفردوا يأخذا جميع المال، أما ذوو الأرحام فكل قريب ليس بذي فرض ولا عصبة (محمد

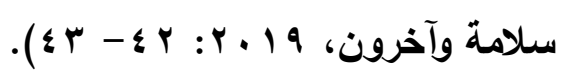
أما عن الفروض المقدرة في القرآن الكريم فهي ستة: النصف، والريع، والثمن، والثلث،

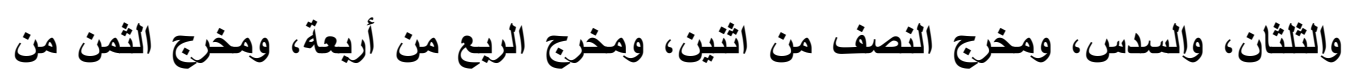

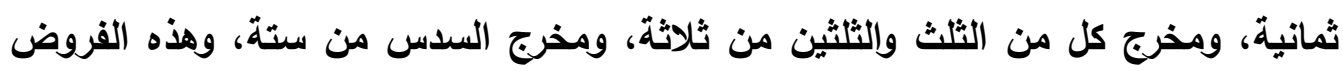

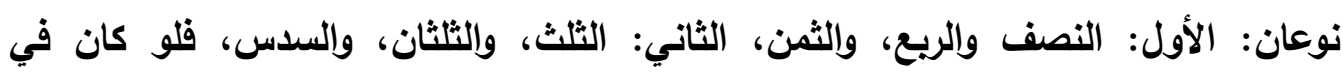

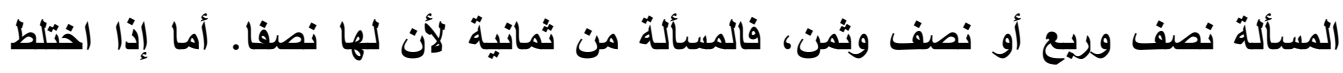

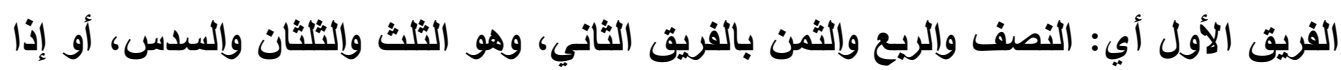

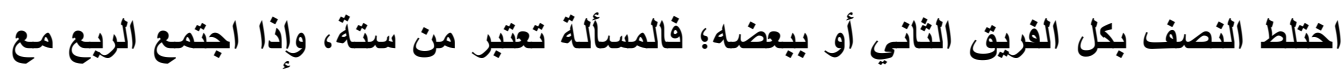

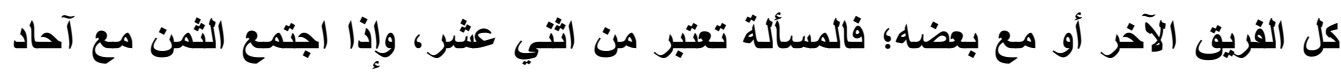
الفريق الآخر؛ فالمسألة من أريعة وعشرين، ثم إذا صحت الفرئة الفريضة من المخارج المذكورة؛

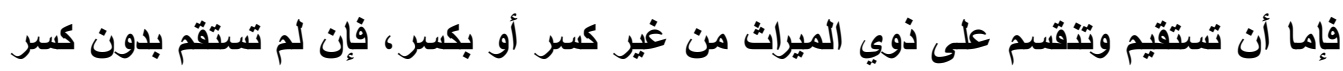

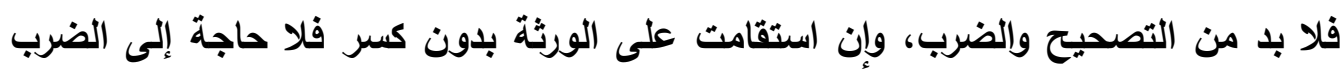

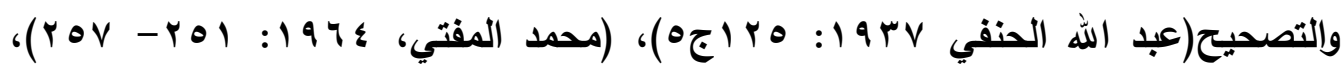

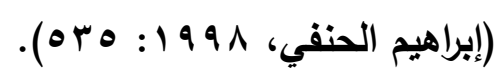

مفاهيم علم الفرائض:

تدرس الطالبة في كلية الثريعة والقانون مفاهيم علم الفرائض والتي تعد أسـاس العلم

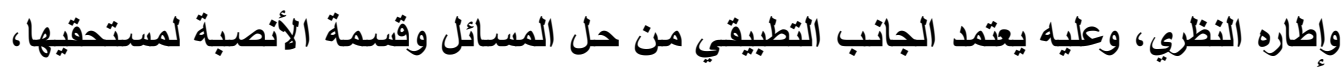
فدراسته لازمة لأنه حين تدرس الطالبة المفهوم وتفهم الأدلة الواردة فيه ثم تطبق المبائل المسائل

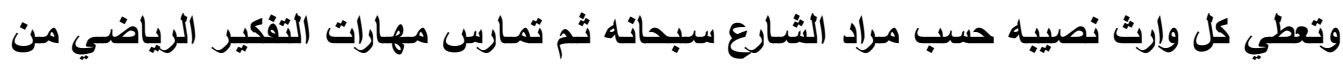

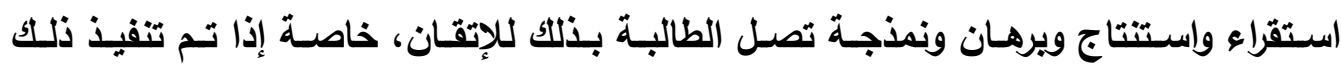

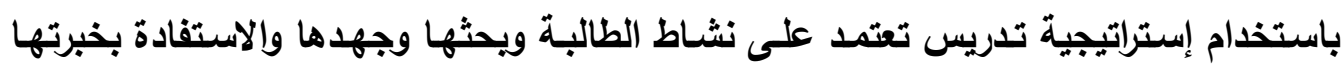
ودراستها السـابقة والبنـاء عليها مثل إستراتيجية دائرة التطلم المدعومـة بالأنثطة الإثرائيسة التقنية. وتدرس طالبة الفرقة الرابعة شعبة الثريعة والقانون مفاهيم رئيسة في علم الفرائض منها: الإرث بالفرض- الإرث بالتعصيب- الحجب- الحساب في علم الفرائض، ويتفرع عنها مفاهيم 
فرعية، وقد اهتم البحث بتمية هذه المفاهيم خاصة دون غيرها لعدة أسباب هي: أهمية هذه المفاهيم للطالبة، ولأنها يرتبط بها جاتب تطبيقي من حل مسائل وقسمة للأنصبة، كمـا أنها

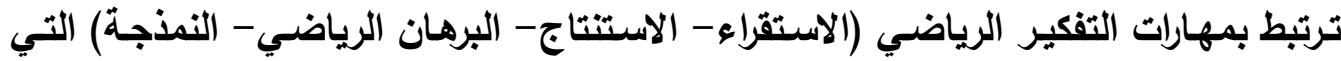
سعى البحث لتنميتها.

\section{تصريف المفهوم: ت تصني}

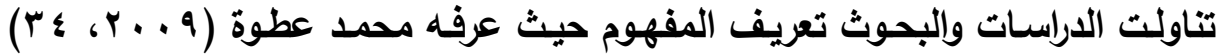
بأنـه: "عمليـة عقليـة تقوم على تنظيم المعلومـات المتصـلة بخاصية واحدة أو أكثر تتصل بالأشياء، أو المواضيع، أو العمليات، وإلتي تحدد مـا إذا كان شينًا معينًا، أو مجموعة معينة

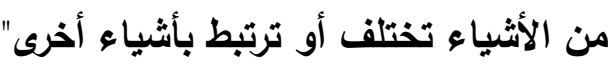

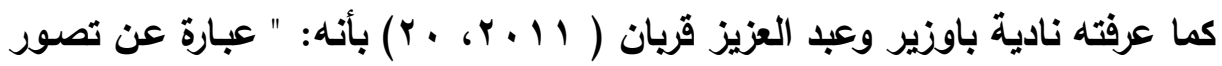

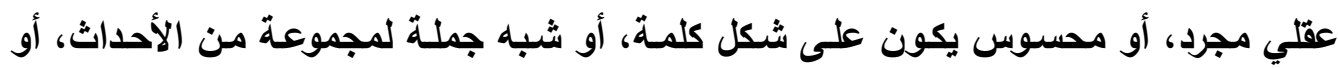
المواقف، أو الحقائق العلمية المتطورة". مما سبث يتبين أن المفهوم ليس محددًا أو ثابتًا، وإنما يتغير تبعًا لاختلاف الخلفية المعرفية للمتخصص، وتبعًا لنوع ومستوى المفهوم المراد تعلمـه، كمـا يرجع الاختلاف أيضًا

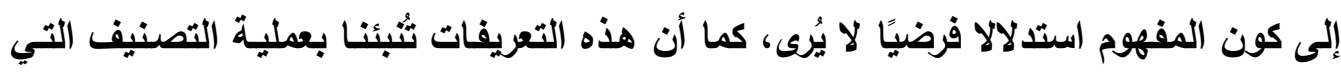
يقوم بها المفهوم في ضوء السمات، أو الخصائص المشتركة بين عدة مواقف أو أثياء. ومن خلال الاطلاع على العديد من الأدبيات وإلدراسات السابقة وجد أن هنـاك عوامل مؤئثرة في تنمية المفهوم تتمركز في معظمها حول ثلاثة محاور أساسية؛ منها مـا يتعلق بالمفهوم

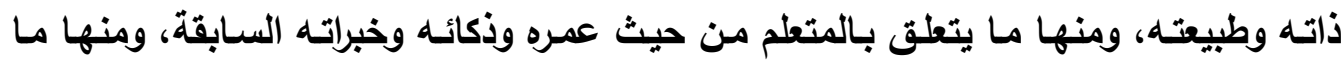
يتعلق بالموقف التعليمي، وتفصيل هذه العوامل كما يلي:

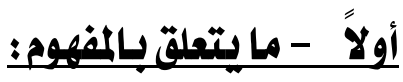

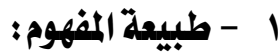

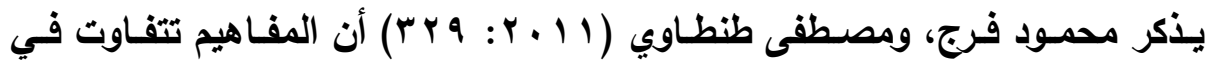
درجـة صـعويتها وسـهولتها، فالمفـاهيم الحسـية أســهل في تعلمهـا مسن المفـاهيم المجـردة، والمجردة أسـل في تعلمها من المفاهيم المتحدة، والمتحدة أسـهل في تعلمها من المفاهيم 
المنفصلة، والمنفصلة أسهل في تعلمها من المفاهيم المترابطة، فالمفاهيم تفرض على المعلم الوعي الكامل بطبيعتها؛ حتى يتسنى له اختيار الطريقة الأنسب لتدريسها.

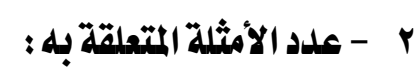

لمـا كـان المتعلم كثير النسيان قليـل التركيز والانتبـاه، وجب تقديم عدد كـاف مـن

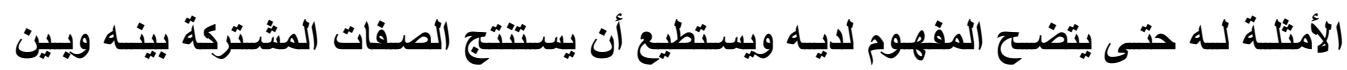
المفاهيم الأخرى. ثانياً - ما يتعلق بالمتعلم: ا 1

يتفـاوت مستوى فهم وإدرالك المفهوم بتفـاوت عمر المتعلم ودرجـة ذكائهـ وإستعداده

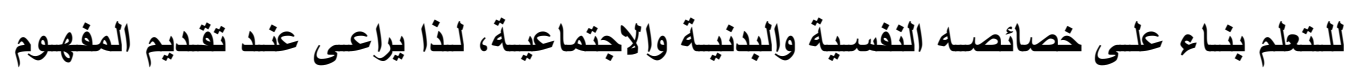
للمتعلمين أن يقدم بأكثر من طريقة لمراعاة تلك الفروق. r هنـاك علاقة طرديـة بـين اكتسـاب المفهوم وخبرات المـتعلم، فكلمـا كثرت معلوماتـهـ السابقة المتعلقة بالمفهوم المراد تعلمـه سـاعده ذلك على روئيـة العلاقات بينـه ويبين المفـاهيم الأخرى، وكلما ضعفت خبرته صعب عليه تعلم المفاهيم الجديدة. ثالثًا - ما يتعلق بـالموقف التمليمي: وكلئ مـن حيث طريقـة التدريس والوسـائل التعليميـة المستخدمة فيـه؛ لذا ينبغي على كل مسن

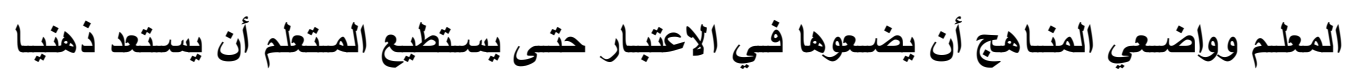

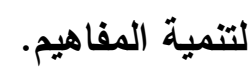
مما سبق يتضح أهمية مراعاة العوامل المتعلقة بالفروق الفردية بين المتعلمين، والاهتمام

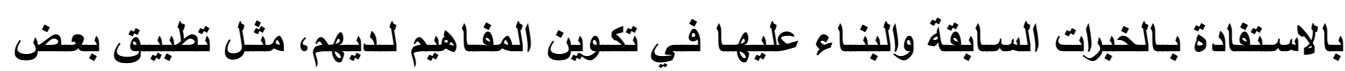
استراتيجيات التدريس البنائية التي تهتم بنشاط المتعلم وتبني على خبراته السـابقة مما يعمل على تنمية مفاهيمه. 
أنواع المفاهيه:

اختلف المريون والباحثّن في تصنيف المفاهيم إلى أنواع مختلفة، وقد يكون السبب في ذلكـ راجعًا إلى الكـم الهائسل مـن المفـاهيم، وإلـى فلسـفة المصنف والغغايـة مـن وراء عمليـة التصنيف، ويالتالي يمكن تصنيف المفاهيم العلمية كما يلي: أ- تصنيف المفاهيم على أساس العلاقة بين مكوناتها:

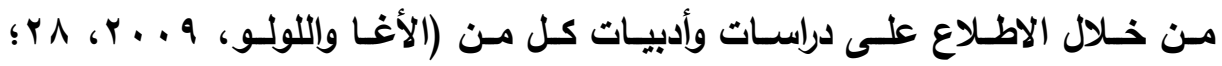
(Francois, 2009,494 صنفوا المفاهيم على أساس العلاقة بين مكوناتها كالتالي:

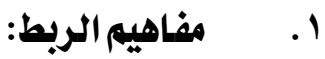
وهـي المفـاهيم المعروفة بمجموعـة من الخصـائص المشتركة بين مجموعـة مـن الأششياء والمواقف، ويتم اشتقاقها من ريط أحداث معينة، أو ملاحظات معينة ببعضها.

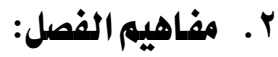
وهذه المفـاهيم يـتم تعريفها مـن خـلال وجود بعض الخصـائص وغيـاب خصـائص أخرى، وتتميز بأنها الأكثر اتساعا والأكثر مرونة، كما أنها تتضمن مجموعة من الخصائص المتميزة

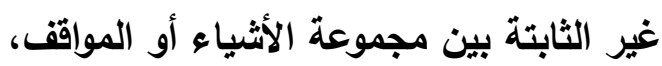

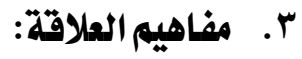
وهي المفاهيم التي تبحث عن علاقة تربط بين مفهومين، أو عدة مفـاهيم تعتمد تركيبة القواعد فيها على العلاقات. ب- تصنيف المفاهيم على أساس درجة الحسية والتجريد للأثياء: وهذا التصنيف يعتمد على أسساس مستوى التجريد، ويضم نوعين وضحهما كل من دن

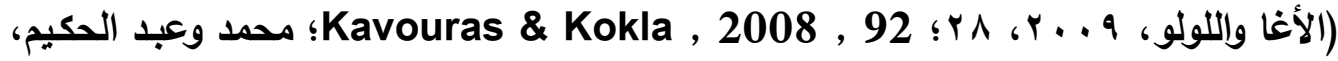
年 • المفاهيم المادية ( الحسية ): وهـي المفـاهيم التـي تـدرك بـالحواس والتـي يـتم تعلمهـا عن طريـق الملاحظة، أو الخبـرة المباشرة، أو غير المباشرة، وهذا النوع يعتبر أسهل أنواع المفاهيم في العملية التعليمية. 


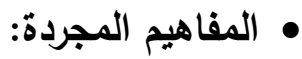

وهي المفاهيم التي تبدو أكثر صعوية أو تجريدا من المفاهيم المادية، ويتم تعلمها عن طريق الخبرات البديلة والأمثلة الرمزية.

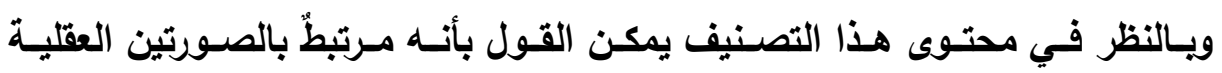
والحسية، فالتصنيف المـادي يمكن تنميته لاى صغار العقول من خلال الملاحظة المباشرة،

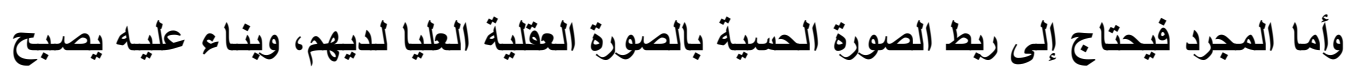
أكثر صعوية لارتباطه بالتفكير المجرد. ويعد هذا التأصيل السـابق يتضـح أن هنـاك تصنيفات متنوعة للمفـاهيم، إلا أن أكثر التريويين قد اتفقوا على قسمين رئيسين لا يخلو منهما أي مـادة تعليمية، أولهمـا: المفاهيم

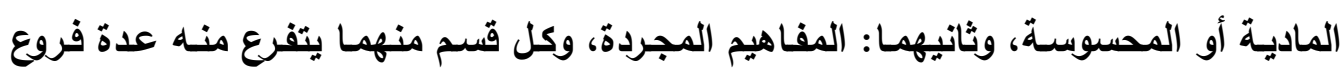
أخرى.

ومـن المعلوم للاراسين في الأزهر الثـريف أن مفـاهيم عـم الفـرائض يـتم تدريسـها

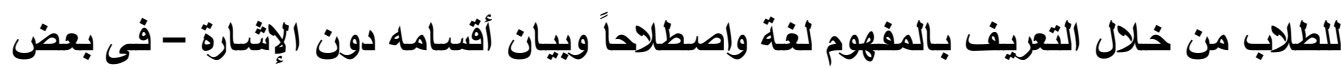
الأحيان - إلى العلاقات بين هذه المفاهيم، أو دمجها بمـا هو موجـود في البنيـة المعرفية

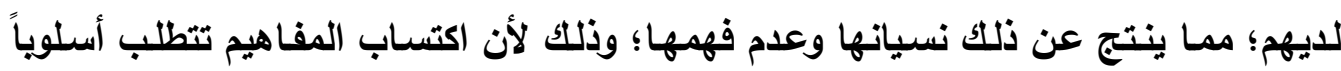
تدريسياً مناسباً؛ لضمان سـلامة تكوينها ويقائها والاحتفاظ بها، لذا ينبغي على عضى عضو هئئة

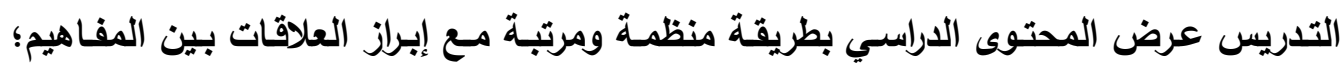
وذلكك لكثرتها وتشـعبها وتثــابك موضـوعاتها، ودمجها بمـا هو موجـود في البنيـة المعرفيـة لايهرم. وكذلك يجب عليهم أن يتخلوا عن طرائق التدريس القائمـة على الحفظ والاستظهار،

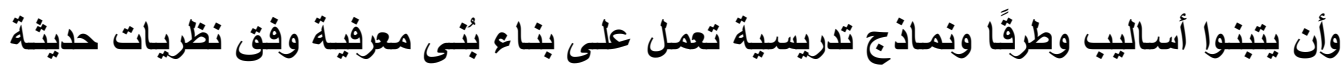

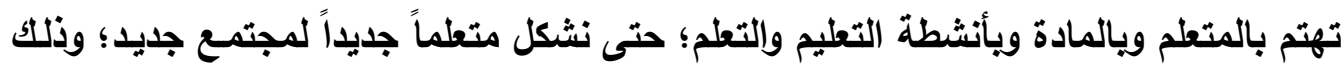

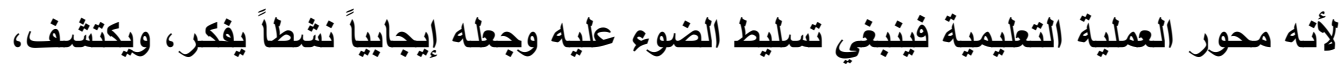

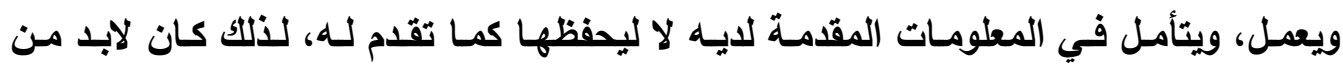
التفكير في استراتيجيات ونماذج تركز على نشاط الطالب، مثل: إستراتيجية دائرة التعلم القائمـة على النظرية البنائية. (شحاتة، V . . Y ، Y Y I ). 
واقع تدريس علم الفرائض فيكليـات الشريعة والشريعةوالقانوز: - علم الفرائض من العوم الضرورية التي يدرسها الطلاب في قطاع كليات الثريعة في الفرقة

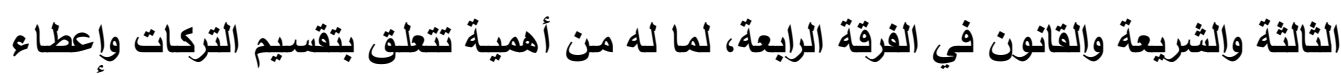

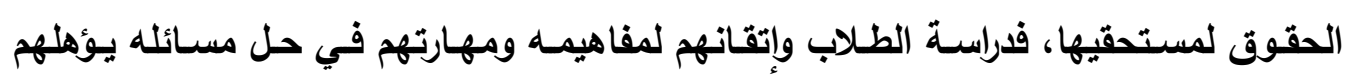

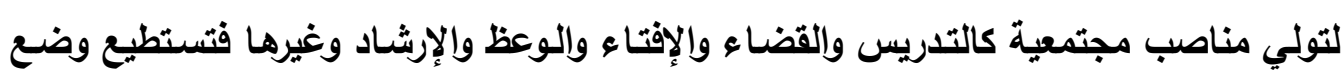

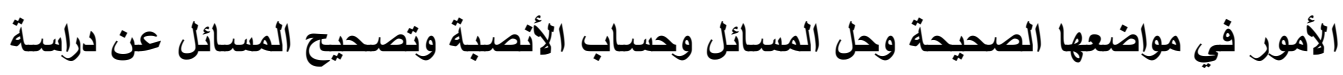
مسبقة وفهم وعلم وتدريب.

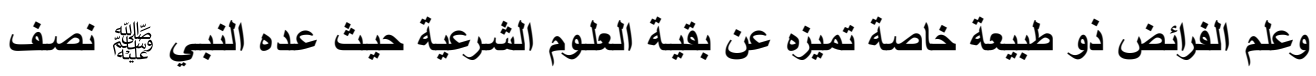

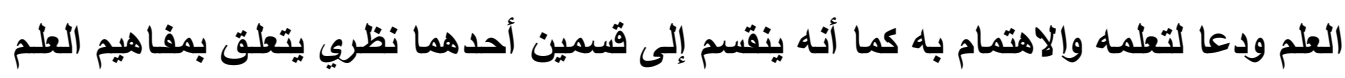

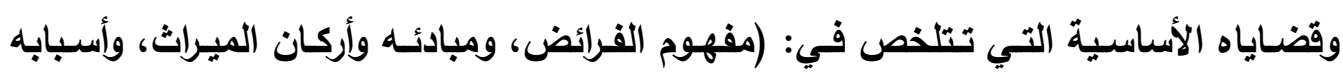

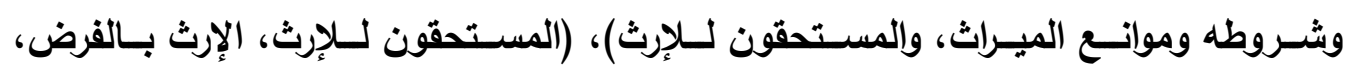

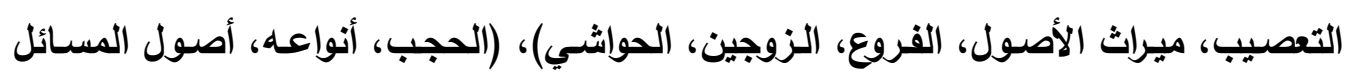

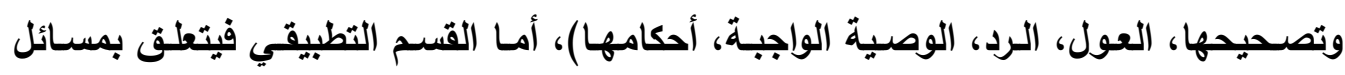

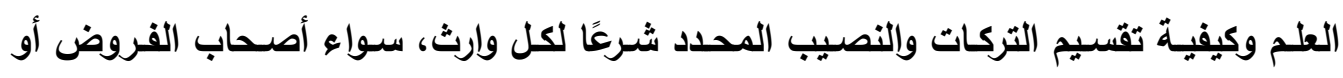
العصبات أو الزوجين أو غيرهم. - - والواقع الفعلي يشير إلى ضعف الطلاب في مهارات حل المسائل التطبيقية في علم الفرائض

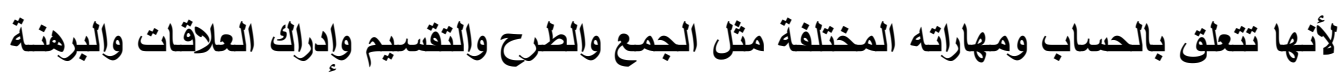

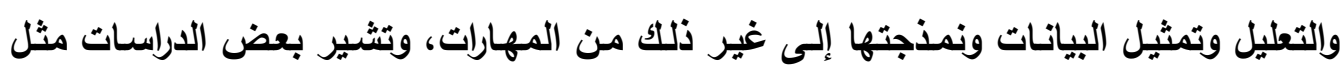

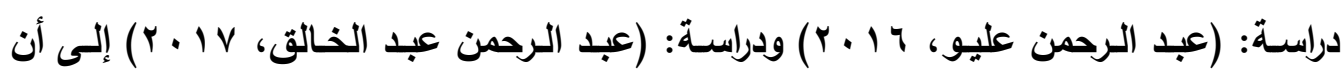

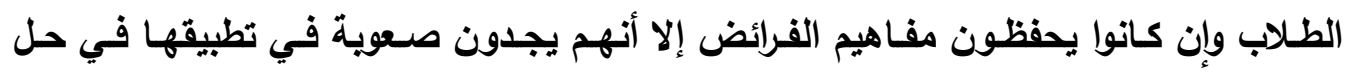

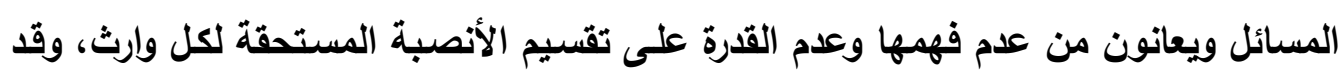

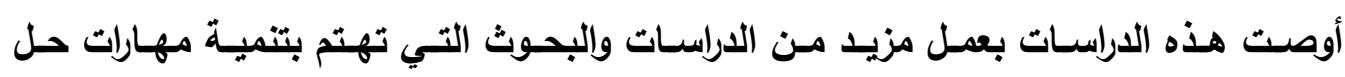

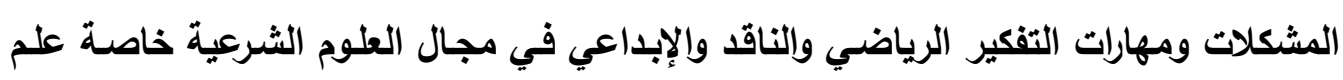

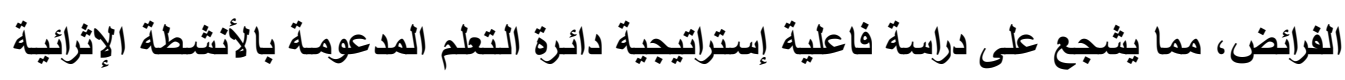
التقتيـة لتنميـة مهـارات التفكير الرياضـي لـدى طالبـات الثـريعة والقـانون بجامعـة الأزهـر الثريف. 


\section{المحور الثاني \\ التفكير الرياضي، أهميته، مهاراته}

يتطلب الجانب التطبيقي من علم الفرائض مهارات خاصة لحل مسائله وإعطاء كل وارث حقه الهيته

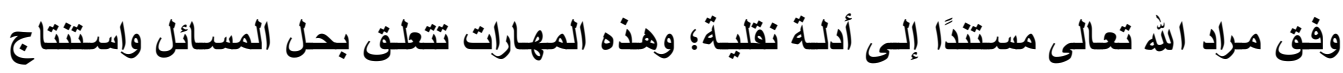
الأنصبة من الأدلة ثم صياغة البرهان المكون من معطيات ومطلوب وتقويم ومن ثم نمذجة

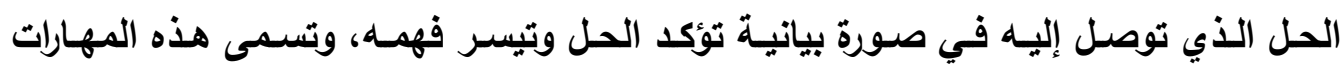
بمهارات التفكير الرياضي، وفيما يلي عرض لمفهوم التفكير الرياضي، وأهيته، وأهم مهاراته

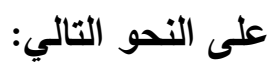

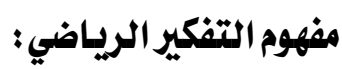
هو التفكير الذي يقوم على الأدلة ويساعدنا على الوصول إلى أفضل إجابات الأسئلة التي

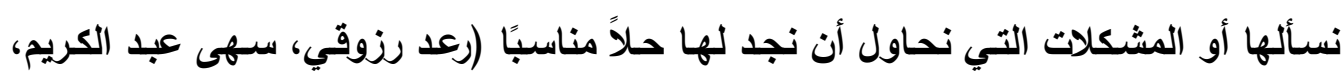
. (rVT:r.lo

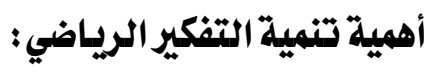

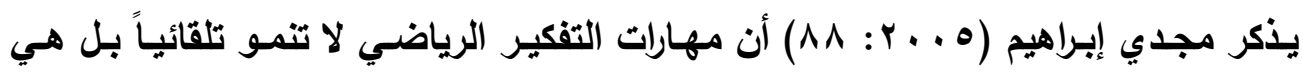

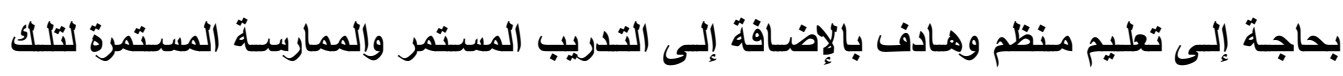

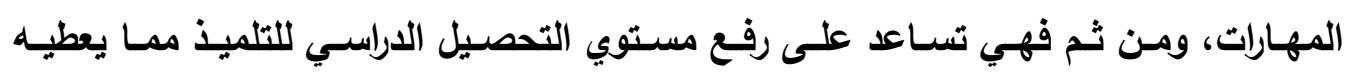

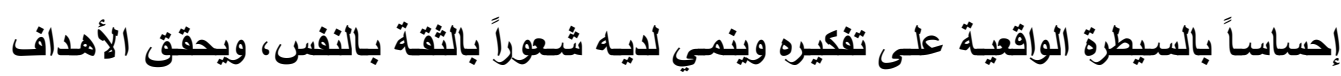

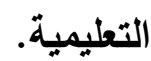

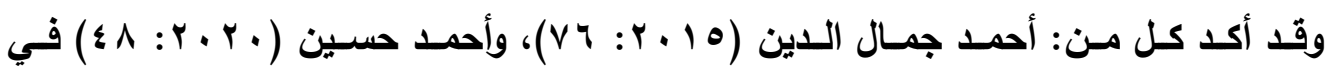
الراستهما على أهمية تنمية التفكير الرياضي للأسباب الآتية:

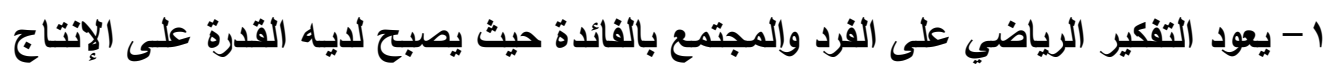
مما يعمل على خذمة مجتمعه.

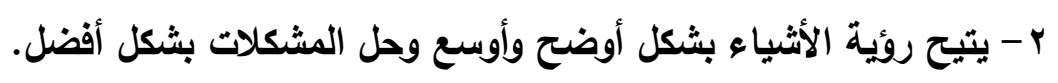
ب- بتيح الفرصة للتفكير الإيجابي وتحويل الطلاب إلى مفكرين منطقيين.

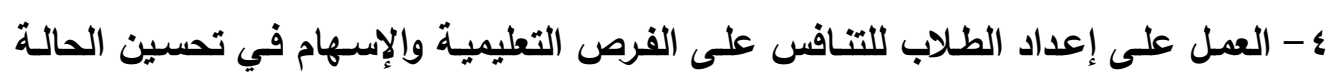
النفسية لايهم واكتساب المعرفة الجديدة. 
ه - مسـاعدة الطـلاب في الانتقـال مـن مرحلـة اكتسـاب المعرفـة إلى مرحلـة توظيفهـا في

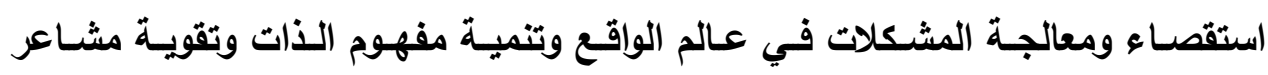
الانتماء والاحساس بالمسؤولية نحو المجتمع.

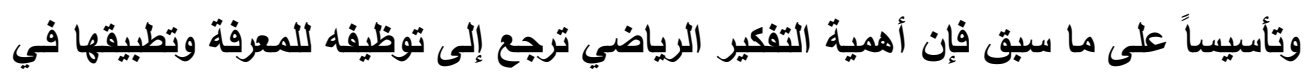

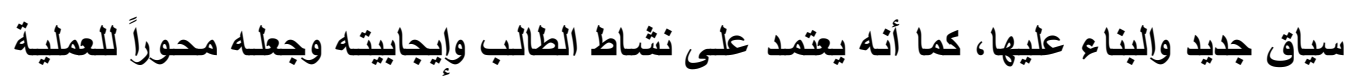

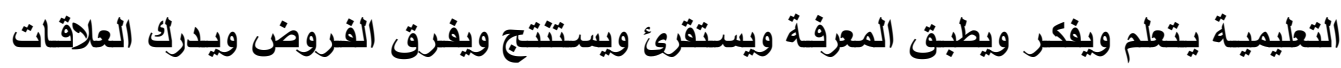
ويبني النماذج ويبرهن ويعلل على حل مشكلة ما.

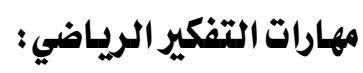
باستقراء عدد من الدراسـات التي تناولت تنمية مهارات التفكير الرياضي أمكن استخلاص

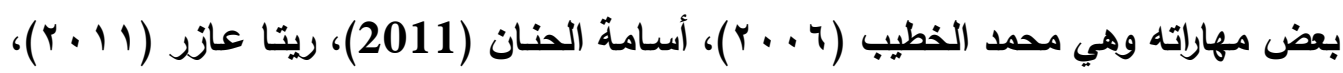

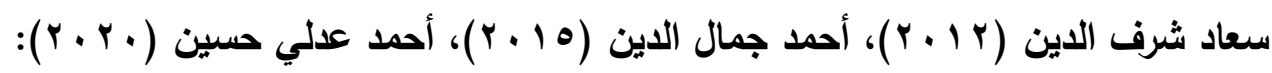

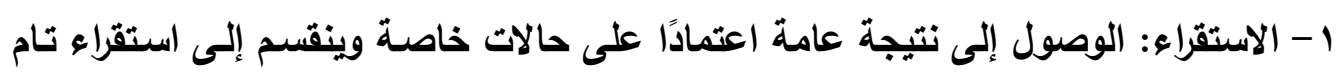
واستقراء ناقص (محمد العبسي، 9 . . ب ب: 9 ـ 1). والاستقراء التام هو الوصول إلى القاعدة بعد استقراء جميع الحالات الفردية أمسا الناقص فهو

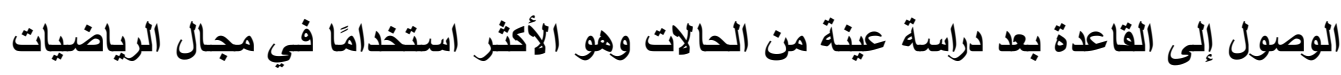

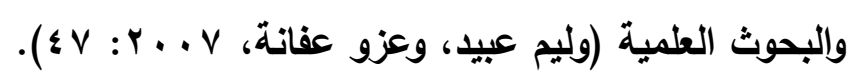

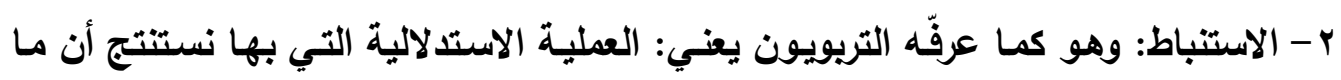

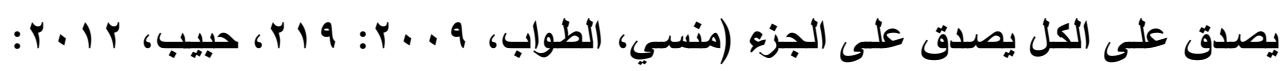

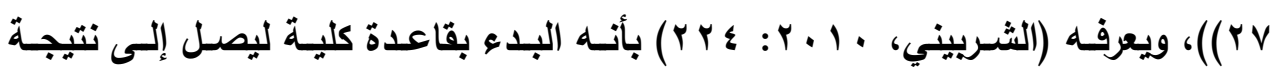
تنطبق على المثال الجديد. ب- حل المشكلة الرياضية: نشاطا عقليا عاليا يتضمن الكثير من العمليات العقلية المتداخلة مثل التذكر والتعميم والتجايد والتحليل والتركيب وسرعة البليهة بالإضـافة إلى المعلومـات

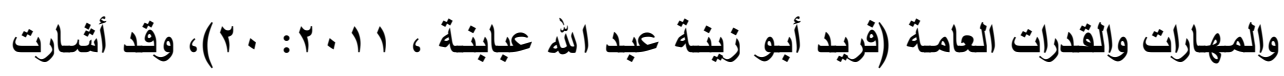

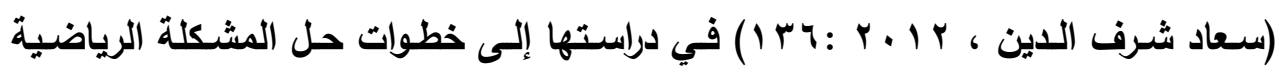
وتتلخص في: مرحلة تكوين الحل، وتتفيذ الحل، ومراجعة خطة الحل. 
ع - التفكير المنطقي: قدرة عقليـة تمكن الفرد من الانتقال المقصود من المعلوم إلى غير

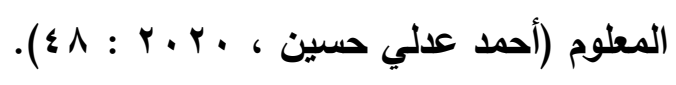

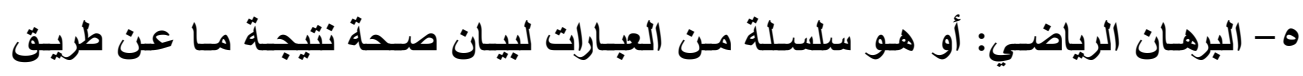

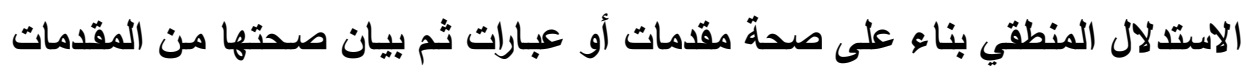

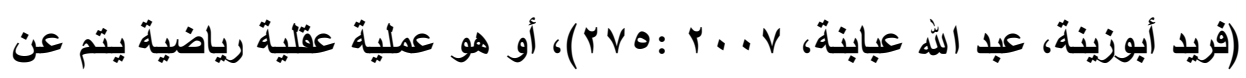

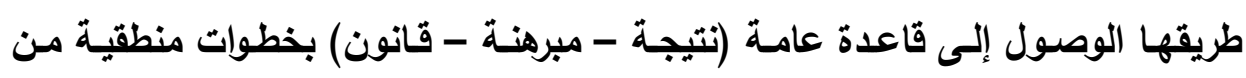

خلال دراسة عدد من الحالات ومنها:

- - التوصل إلى قاعدة عامة من حالات خاصة.

- - استخلاص نتائج من معلومات معطاه.

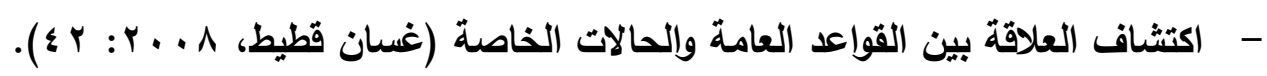

$$
\text { مهارات البرهان الرياضي: }
$$

- التخطيط للبرهـان الرياضي وتتضمن (تحديد المعطيات في المسالة -تحديد المطلوب

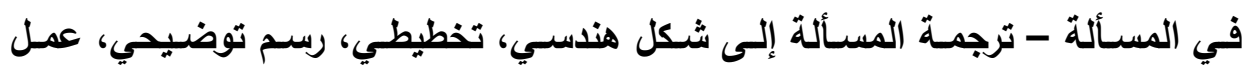
نموذج معين) - - بنـاء وصـياغة البرهـان والتعبيـر عــه (اشـقاق النتـائج مـن المعطيـات - الـريط بـين نتيجتين - التوصل إلى المطلوب من خلال متابعة النتائج في صورة مكتوية).

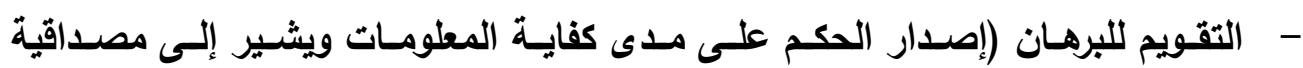
العبارات، أو إدراك الحكم موضع البرهان (عدنان يوسف، عبد الناصر الجراح، 9 . . ب : .$(\mathrm{\vee} \wedge$ צ- التخمين: هو الحرز الواعي، وهو الطريقة الرئيسة للاكتشاف.

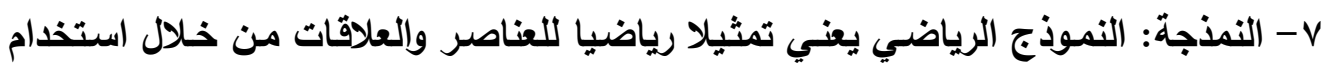

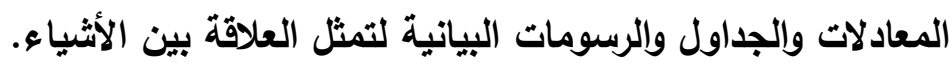

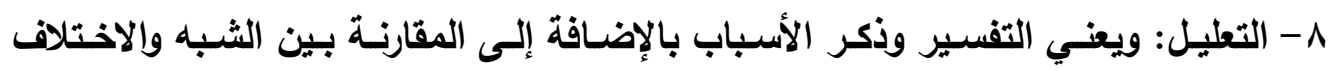

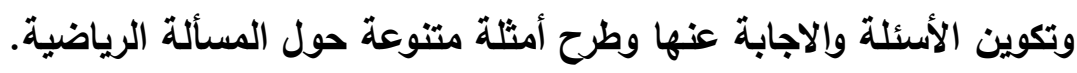

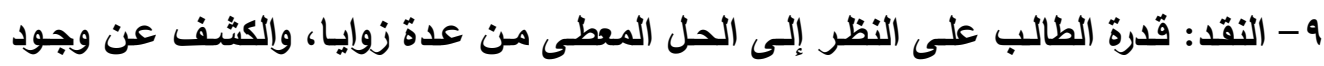
الخطأ في الحل والحل بطريقة أخرى أسهل وأوضح. 


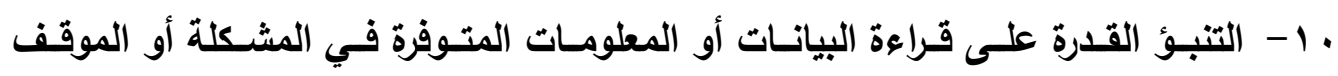

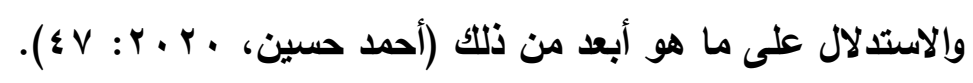

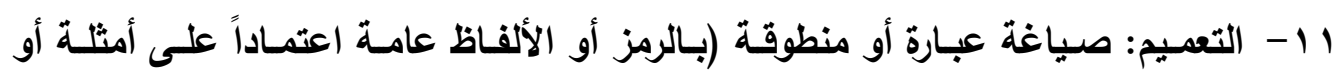

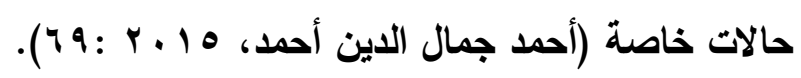

r ا - الاستنتاج: وصول الطالب إلى نتيجة خاصة اعتمادا على مبدأ أو قاعدة عامـة (غسان

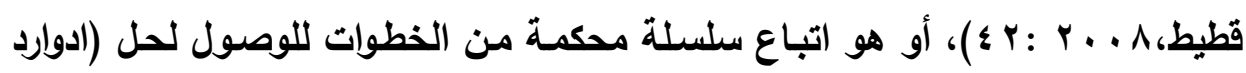

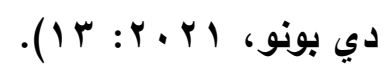

وقد اختـارت الباحثة أريـع مهارات وعملت على تنميتها في هذا البحث وهـي: (مهارات

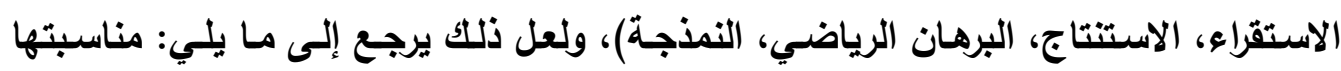

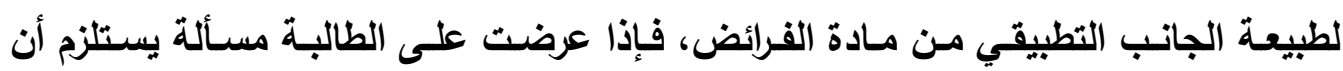

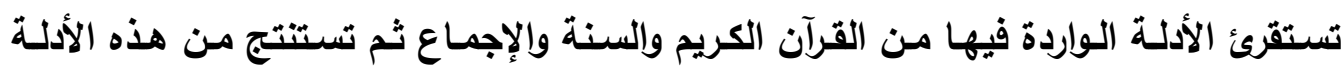

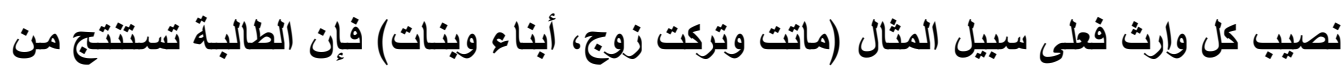

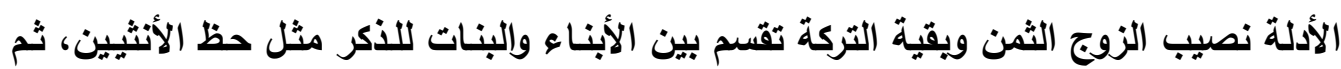
تقوم الطالبة بصياغة البرهان الرياضي المكون من معطيات، مطلوب، تقويم، ثم تقوم بنمذجة البيانات والحل الذي توصلت إليه في صورة بيانية.

\section{المحور الثاثث}

\section{إستراتيجية دائرة التعلم الملدعومة بـالأنشطة الإثرائية التقنية}

تعتمد إستراتيجية دائرة التعلم على أسس نظريـة بياجيهه في النمو العقلي التي تعتمد على

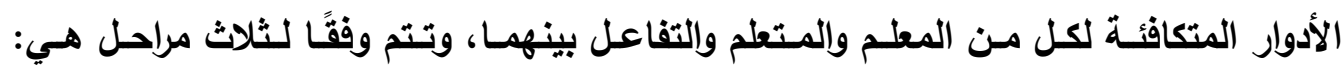

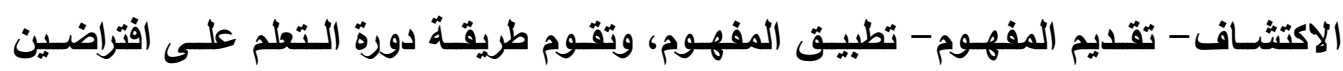
أساسيين من افتراضات بياجيه في النمو المعرفي هما:

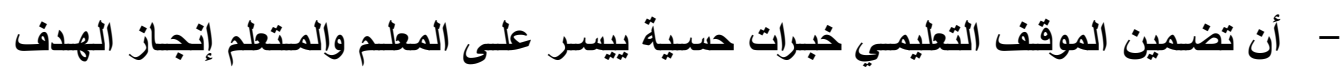
التعليمي.

- - أن الخبرات التي تتضمن تحديًا لتفكير المتعلم تعكس مـا لايـه من اعتقادات عن العالم

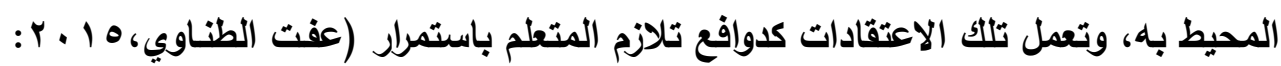


وتتلخص مراحل الإستراتيجية في الثلاث مراحل التي يلخصها الثكل التالي: (حسن خليفة

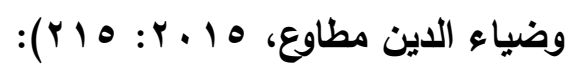

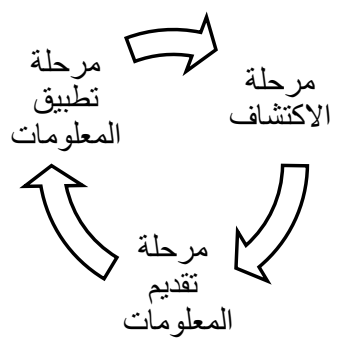

شكل( (1) مراحل إستراتيجية دائرة التعلم

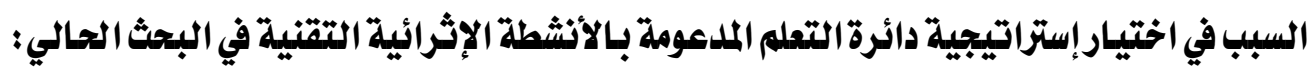
1 - استمداد إستراتيجية دائرة التعلم إطارهـا النظري من نظريـة بياجيهه في النمو العقلي التي ترتكز على عمليتي التمثيل حيث يعرض المفهوم على الطالبة ويتطلب منها القيام بأنشطة متعددة للبحث عن معلومات جديدة تصل إليها بنفسها ويوجهها لها المعلم، ثم يقدم المعلم

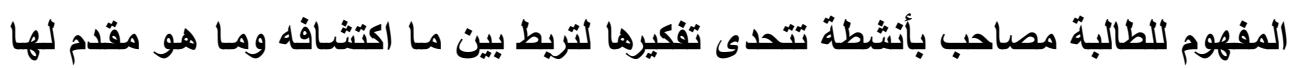

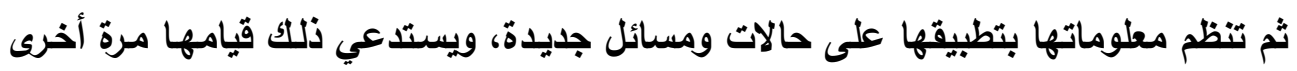

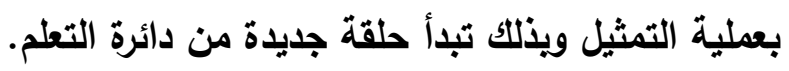

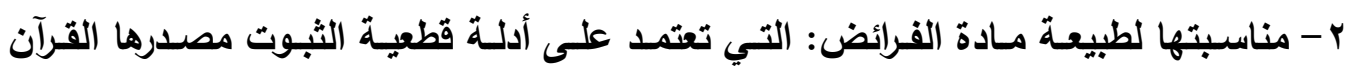
والسنة، ثم تعرض الطالبة المسائل على هذه الأدلة في صورة تعينها على استنتاج الأحكام

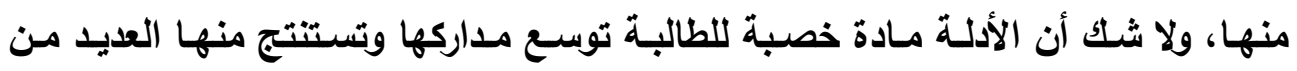
الأحكام وتستخدمها في التعليل للحل الصحيح في صورة تعاونيـة مـع مجموعتها أو في صورة فردية. ץ- مناسبتها لطبيعة طالبة الثريعة والقانون: طالبـة الفرقة الرابعة شعبة الثريعة والقانون أوشكت على التخرج من هذا القطاع العريق من جامعة الأزهر الذي يوليهه عناية واهتمام

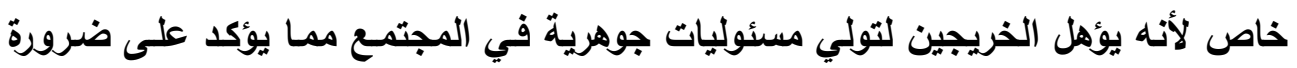

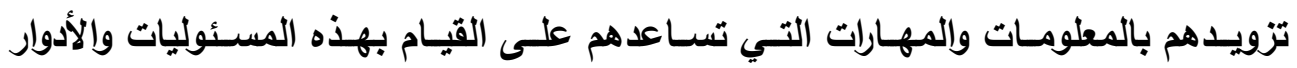

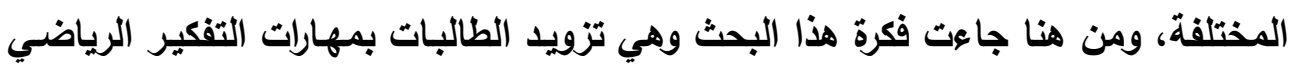

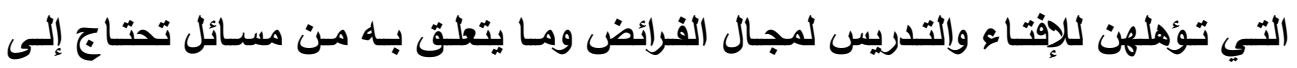
استقراء واستتتاج ويرهان ونمذجة. 
ع - الأنشطة الإثرائية التقبية لها دور كبير في تدعيم إستراتيجية دائرة التعلم وتنمية التفكير

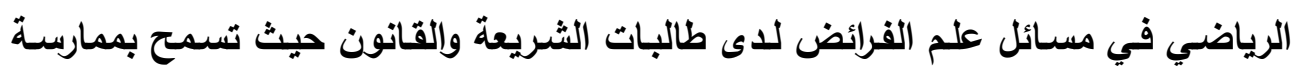

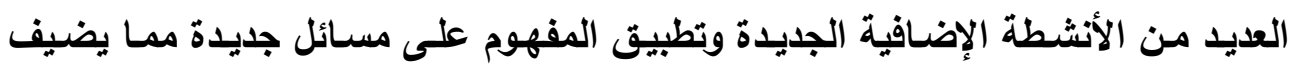

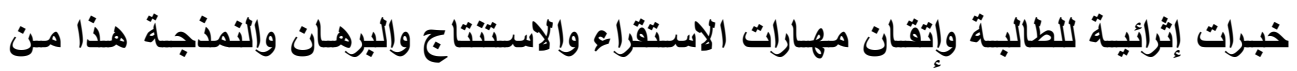

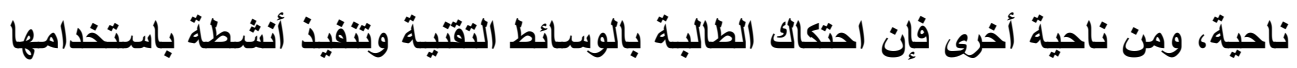

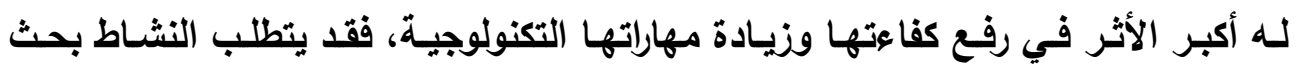
الطالبة عن حل المسألة عبر روابط فقهية يحددها المعلم عبر الإنترنت أو التواصل مـع شخصيات دينية تسهل فهم بعض مفاهيم علم الفرائض وتعين في توضيح البرهان المرتبط

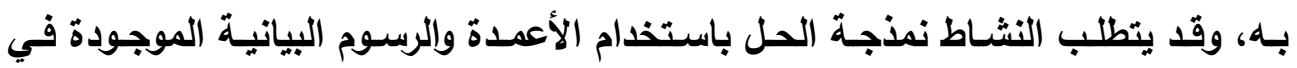

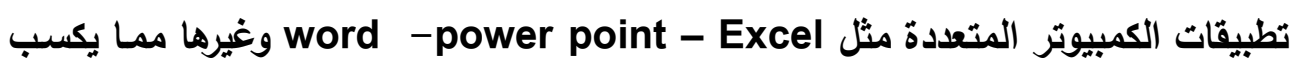
الطالبة العديد من المهارات التي تحتاجها لاحقًا في حياتها العملية "لذا كان من مواصفات

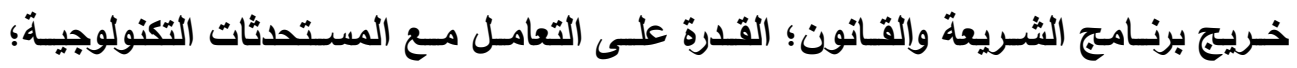

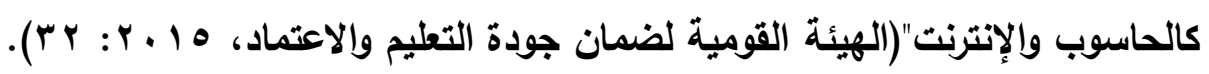

\section{المحور الثرابع}

\section{الأنشطة الإثرائية التقنية}

النشاط التعليمي: هو كل ما تقوم به الطالبة من أجل تعلم موضوع معين داخل أو خارج

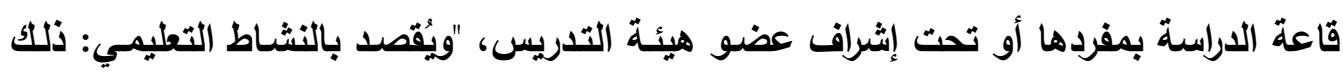

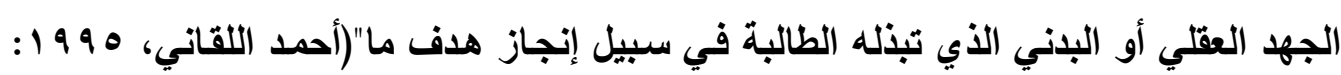
.$(r \circ 0$

معايير تصميم الأنثطة الإثرائية التقنية: هدفت الأنشطة الإثرائيـة التقتيـة تنميـة مفـاهيم علـم الفـرائض ومهـارات التفكير الرياضـي

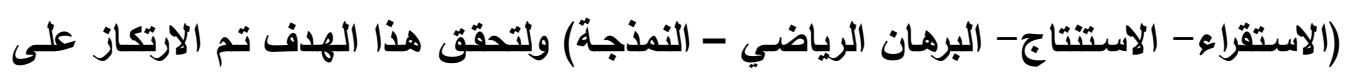
الأسس والمعايير التالية: ا - الاعتماد على الأثكال التقتية المتنوعة والتي وفرتها تجريـة البحث مثنل المواقع الفقهية

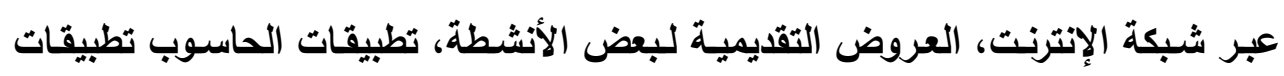


الكمبيوتر المتعددة مثل:( ) power point - Excel-word ، مجموعة شعبة الثريعة والقانون على WhatsApp، شبكة الهاتف المحمول، معمل الحاسوب بالكلية). ץ - إثـراء معرفـة الطالبـات وتوسـيع فهمهـن للمفــاهيم مـن خـلال الأنثـطة التنافسـية بـين المجموعات، أو القراءة الصـامتة لبعض المصادر في علم الفرائض بهرف الإجابـة عن أسـئلة يتطلبها النشـاط، أو البحث عبر الثـبكة عن حل مسـألة معينـة، "فتعمق فهم الطالبـات للمقرر الاراسـي والتطبيـق العملي يســاعدهن على حل المشـكلات الدراسـية

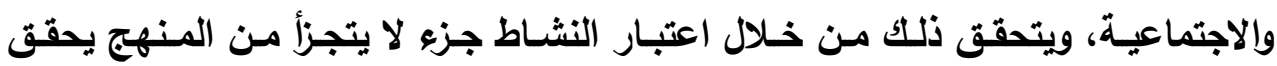

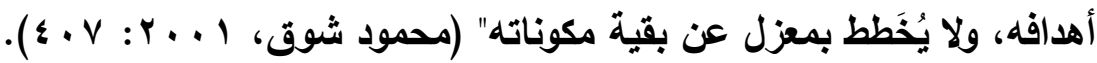

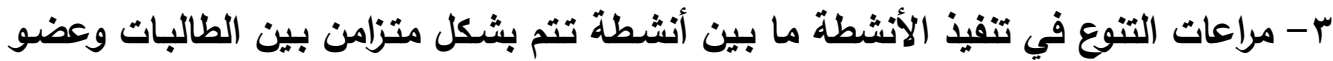
هيئة التدريس والتي يتم التقويم فيها بشكل فوري، أو بشكل غير متزامن بما يناسب وقت

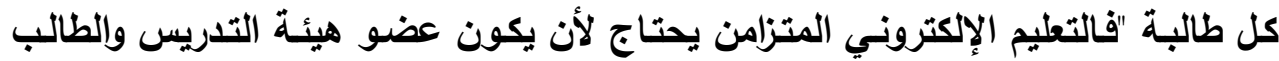
متصلين بواسطة الإنترنت في نفس الوقت، مثل المحادثة والدردشـة الفوريـة، مؤتمرات الفيديو، البـث الحي، أمـا التعليم الإكترونـي غير المتزامن فـلا يلـزم أن يكون الطرفـان متصلين في وقت واحد، فقيه حريـة في اختيار الوقت، مثل البريد الإكترونـي، منتديات

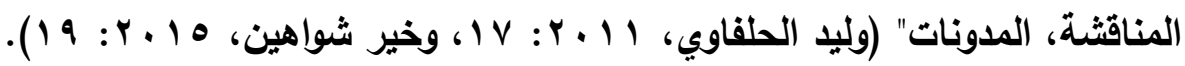
مراحل تنفيذالأنشطة الإثرائية التقنية: مر النشاط التعليمي بثلاث مراحل ترتبط فيما بينها وتتكامل لتحقق الأهداف وهي: 1- التخطيط للنشاط: يعد التخطيط للنشاط من عوامل نجاحه، " فعند التخطيط للنشاط لابد من اختيار ما يناسب قدرات واستعدادات الطالبات، وميولهن، وتوفير الإكانيات والمعدات اللازمة والاستفادة القصوى منها، وتخطيط النشاط ودراسته بتعاون المعلم مـع الطالبات،

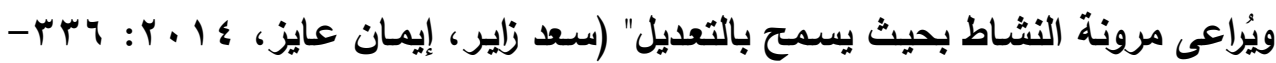

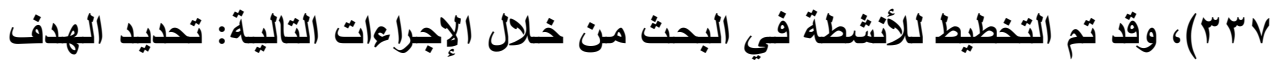
من النشاط - تحديد عناصر النشاط ومكوناته - تحديد المكان والزمان لتنفيذ النشاط. r - تنفيذذ النشـاط: حيث تعاونـت الطالبـات في تنفيـذ النشـاط وقد تمثـل دور عضـو هيئة التدريس في المتابعة المستمرة وتقويم الأداء للتأكد من تحقق الأهداف. 
ب- التقويم والمتابعة: وقد تم ذلكك من خـلال معيار التقويم الجماعي بمقارنـة أداء المجموعة ببقية المجموعات لتحليد المجموعة الفائزة، كما تم استخدام المعيار محكي المرجيع في مي مئي ضوء مستوى الطالبـة الماضـي أو في ضويء درجـة حددها عضو هيئة التدريس مسبقًا للحكم على أداء الطالبة. هذا وقد تم دمج الأنشطة الإثرائية التقتية في كل خطوة من خطوات إستراتيجية دائرة التعلم بهدف إثراء معرفة الطالبات بمفاهيم علم الفرائض وتتمية مهارات التفكير الرياضي لديهن (").

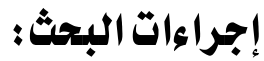

للإجابة عن أسئلة البحث والتحقق من صحة فروضه تم إتباع الإجراءات التالية:

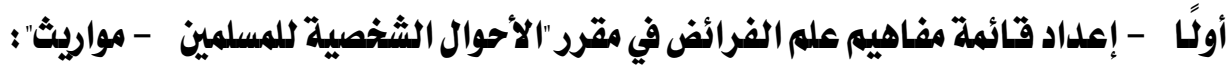
تم إعداد القائمة في ضوء الخطوات التالية: أ- الهـدف مـن القائمـة: التوصل إلـى مفـاهيم علـم الفـرائض المقررة على طالبـات الثـريعة والقانون باعتبـار أنها تمثل نـواتج تعلـم مستهدفة مـن دراسـة الطالبـات لمقرر "الأحسوال الشخصية للمسلمين - المواريث"، وتكونت القائمة من (خمسة عشر) مفهومًا تم تحديدها من خلال تحليل الكتاب المقرر على طالبات الثريعة والقانون، مـع تعريف مختصر لكل

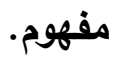

ب- مصادر بناء القائمة: الرجوع إلى بعض المصادر منها:

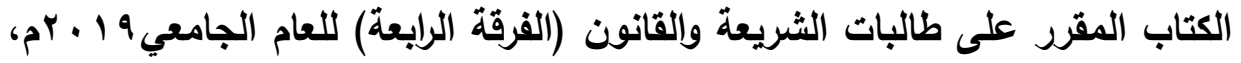
وكتاب الاختيار لتعليل المختار لعبد الله الحنفي (وrv أم)، وكتاب الجامع لأحكام القرآن

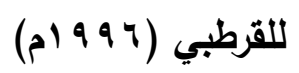

ج- الصورة الأولية للقائمة: تم تنظيم قائمة مفاهيم علم الفرائض، وعرضها على السادة

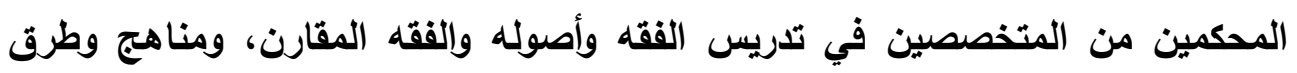
تدريس العلوم الشرعية ( ())، للتعرف على آرائهم وملاحظاتهم حول مدى مناسبتها لطالبات الشريعة والقانون، ومدى شمولها لمقرر "الأحوال الشخصية للمسلمين - المواريث". 
ح- الصورة النهائية للقائمة: بعد الانتهاء من تعديلات المحكين تم وضـع الصورة النهائية

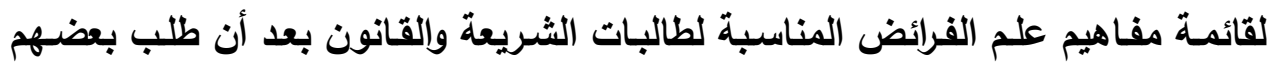
التمثيل لكل مفهوم بعد تعريفه، وكاتت على التحو التالي:

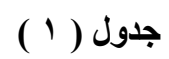
مفاهيم علم الفرائض

\begin{tabular}{|c|c|}
\hline معناه & 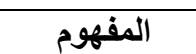 \\
\hline ميراث الأصول وهم الأب و الأم والجد والجُ والجدة). & 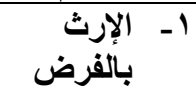 \\
\hline الفروض، وإذا انفرد أخذ جميع المال مثل ليسب له سهم مقدر ويأخذ ما بقي من سهم ذوي & 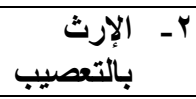 \\
\hline 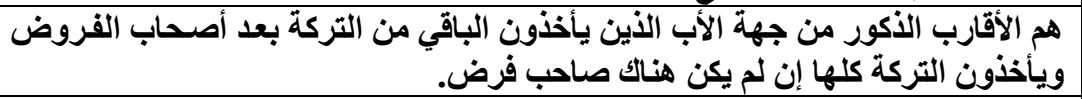 & 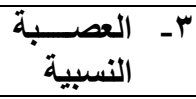 \\
\hline 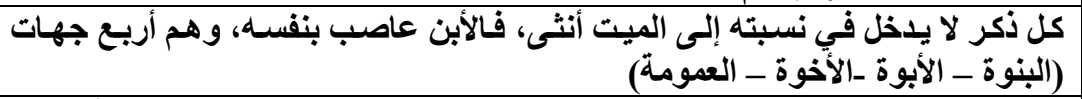 & 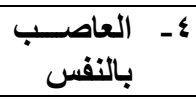 \\
\hline 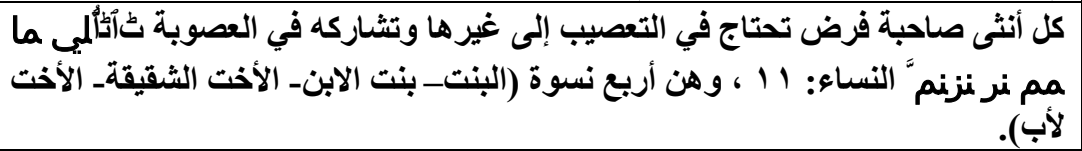 & 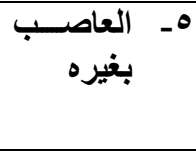 \\
\hline 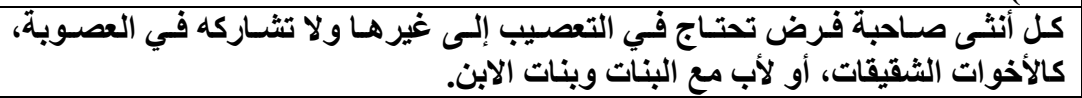 & 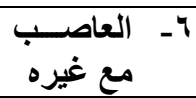 \\
\hline 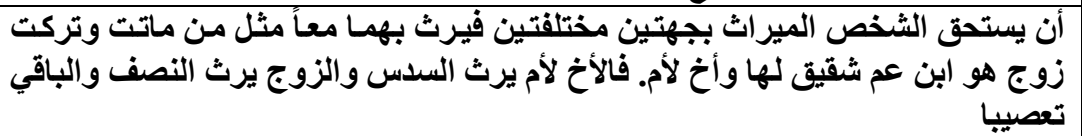 & 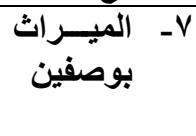 \\
\hline 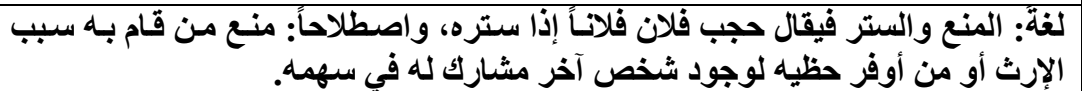 & 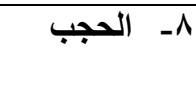 \\
\hline يحجع الثخا الفرع من نصيّه الأعلى وإعطائه النصيب الأدنى بسبب وجود آخر مثل الزوجان & - \\
\hline منع الثخص من الميراث كله لوجود شخص آخر أولى منه بالإرث كمنع الجد بالأب. & • \\
\hline 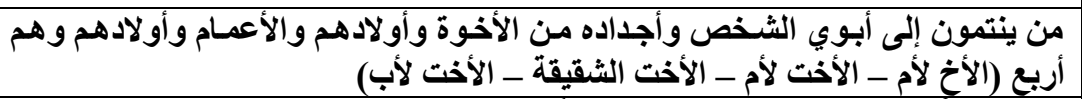 & ا 1 - الحواشي \\
\hline 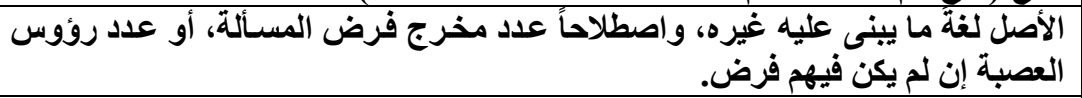 & ا \\
\hline 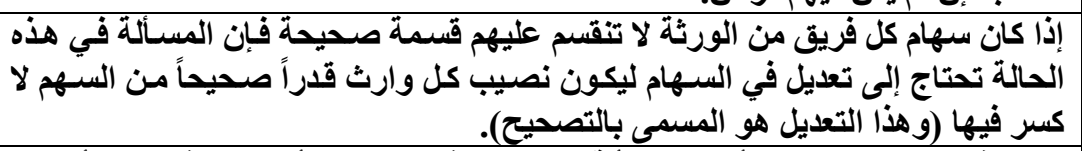 & 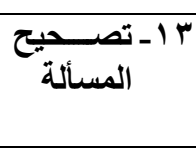 \\
\hline زين الفرضة في عدد السهام عن أصل المسألة، ونقصان في مقادير الأنصباء إذا ضـاق أصلها & 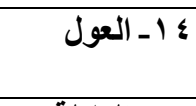 \\
\hline من لا ولا له ولا والد وهم الإخوة الأخوات الأثقاء، والأخوة والأخوات لأب. & 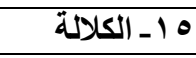 \\
\hline
\end{tabular}


ثانياً - بناء اختبار مفاهيم علم الفرائض في مقرر "الأحوال الشخصية للمسلمين - المواريث" : هدف البحث الحالي إلى تنمية مفاهيم علم الفرائض لاى طالبات الثريعة

والقانون؛ ولتحقق هذا الهدف تم بناء اختبار مفاهيم علم الفرائض، وقد جاء الاختبار في مله صورته المبدئية مكوناً من (ع ب) مفردة من نوعي الاختيار من متعدد والصواب والخطأ،

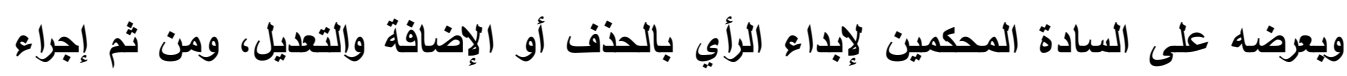

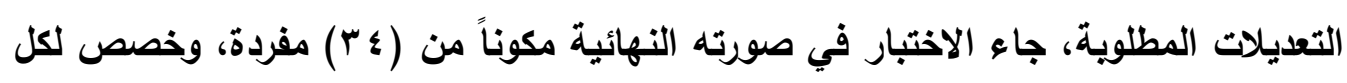

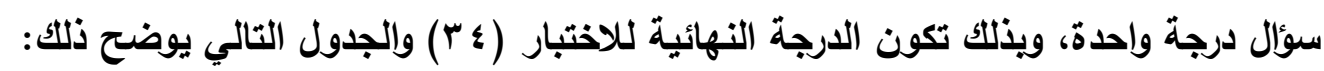

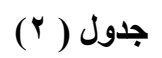

\begin{tabular}{|c|c|c|c|c|c|c|c|}
\hline النسبي & المجموع & ألمفردات & الاختباد & النسبي & المجموع & أرقام المفردات & الاختبار \\
\hline$\%$ & 1 & س (V) & الحجب & $\%$ \% . & 7 & 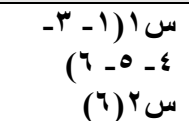 & بالفرض \\
\hline$\%^{\wedge}{ }^{\wedge} \wedge$ & $r$ & 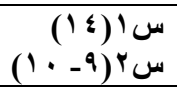 & النقصان & $\%^{\wedge} . \wedge$ & $r$ & $\begin{array}{r}(1 r-r(r) \\
(10) \\
(10)\end{array}$ & بالتعصيب \\
\hline$\%^{0} . \wedge$ & $r$ & سץ(1- (1) & الحرمان & $\%^{r}$ & 1 & س '(9) & النسبية \\
\hline$\%^{0} . \wedge$ & $r$ & س ' (Y $\left.\begin{array}{l}1 \\
1\end{array}\right)$ & الحواشي & $\%^{0.1}$ & Y & 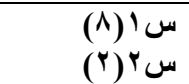 & بالنفاصب \\
\hline$\% \%^{0 . \wedge}$ & r & $\begin{array}{c}-1 \cdot(10) \\
(10\end{array}$ & أصسألة & $\% 0^{0.1}$ & $r$ & س Y (0-0) & العيرهب \\
\hline$\%^{0} . \wedge$ & $r$ & س ' (1) $14\left(\begin{array}{l}1 \\
(1\end{array}\right)$ & تصدئلة & $\% 0^{0.1}$ & r & 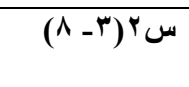 & مع غيره \\
\hline & r & 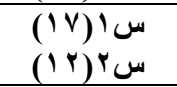 & العول & $\%$ & 1 & سץ(\&) & بوصفين \\
\hline$\%^{\wedge} . \wedge$ & $r$ & 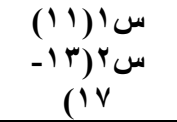 & الكلالة & & & & \\
\hline 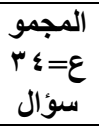 & IV & & & & IV & & الإجمالي \\
\hline
\end{tabular}

ضبط الاختبار:

1 - التجرية الاستطلاعية لاختبار مفاهيم علم الفرائض:

بعد إعداد الاختبار، والتتأكد من صدقه الظاهري بعرضهـ عله على السـادة المحكمين، تم

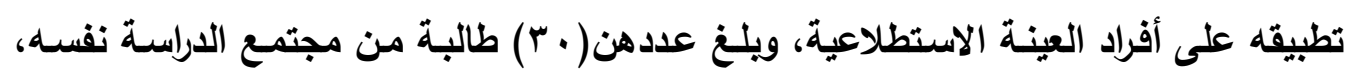


مـن طالبـات الفرقة الرابعة شعبة الثـريعة والقـانون بكليـة البنـات الإسـلامية بأسيوط، وكـان الهُف من تطبيق الاختبار على العينة الاستطلاعية محداً في النقاط الآتية: أ- التأكد من وضوح التعليمات.

$$
\text { ب- حساب زمن الإجابة عن الاختبار. }
$$

ج- حساب معاملات السهولة والصعوية ومعاملات التمييز لأسئلة الاختبار.

د-حساب الاتساق الاخلي للاختبار.

هـ - حساب ثبات الاختبار.

أ- التأكد من وضوح التعليمات

قبـل البداء في الإجابـة عن الاختبـار كـان هنـاك حرص على قراءة التعليمـات من قبل

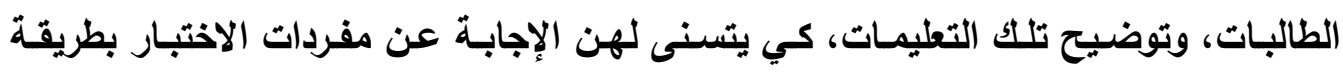
سليمة، حيث تبين أن تعليمات الاختبار واضحة تماماً لجميع أفراد العينة الاستطلاعية. ب-زمن الإجابة عن الاختبار تم حسـاب المتوسط الزمني الذي استغرقته جميع الطالبات في الإجابـة عن الاختبار

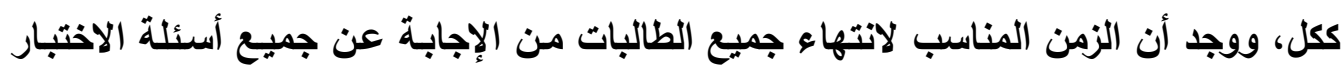
هو: (0 ) دقيقة؛ حيث تم حسابها من المعادلة التالية:

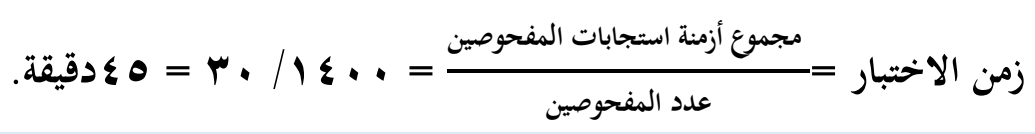

ج- حساب معاملات السهولة والصعوية والتمييز لأسئلة الاختبار تم حساب معاملات السهولة والصعوية لكل سؤال من أسئلة الاختبار باستخدام معادلتي

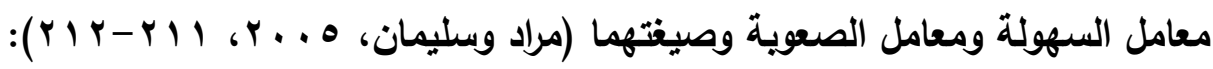

$$
\begin{aligned}
& \text { معامل السهولة } \\
& \text { ن (مج ص + مج خ) } \\
& \text { معامل الصعوية = } 1 \text { - معامل السهولة } \\
& \text { ن = عدد أفراد العينة الاستطلاعية }
\end{aligned}
$$

مج ص = عدد الطالبات اللاتي أجبن إجابة صحيحة عن السؤال. 
مج خ = عدد الطالبات اللاتي أجبن إجابة خاطئة عن السؤال.

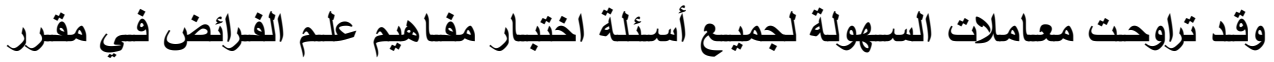

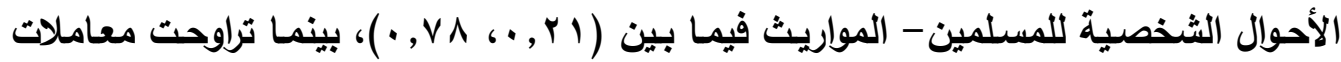

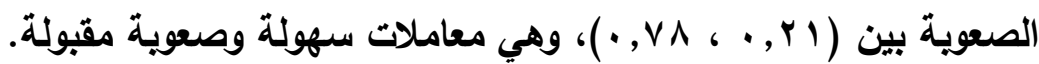

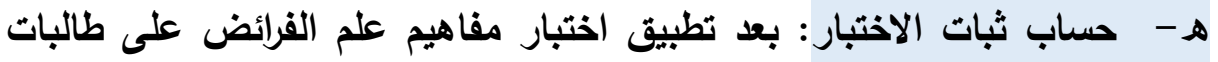

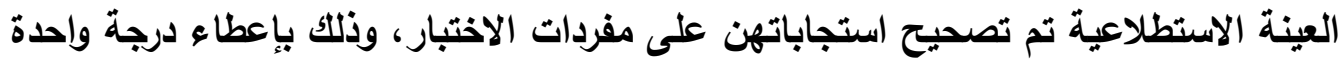

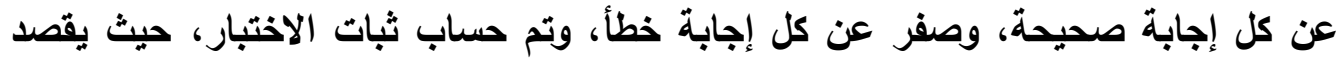

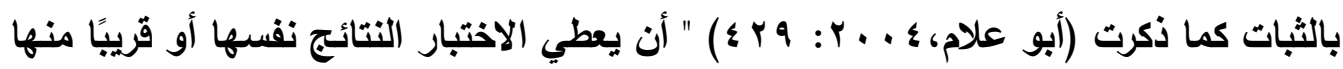
في حالة استخدامه أكثر من مرة، وفي هذه الحالة يوصف الاختبار بأنه على درجة عالية من التان

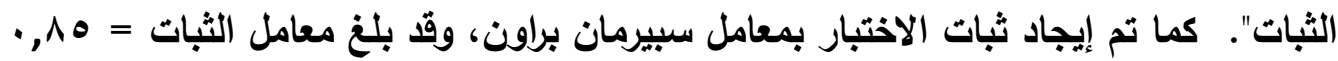
وهي قيمة مرتفعة سمحت باستخدامه كأداة لقياس مفاهيم علم الفرائض لاى الطالبات، ومن فئن ثم الحصول على نتائج أمكن الوثوق بها. الاختبار في صورته النهائيةِ("): بعد الانتهاء من تعديلات المحكمين ومراجعة مفردات

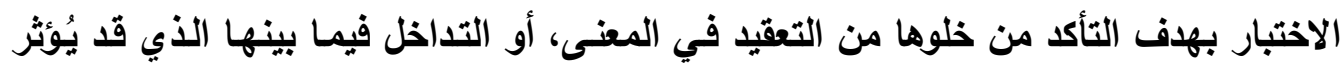
في تحقيق الهـف من الاختبار. في ضوء ما أسفرت عنه آراء ومقترحات لجنة التحكيم تكون التهات

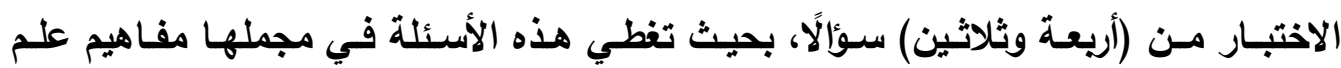
الفرائض المتضمنة في المقرر الاراسي: "الأحوال الثخصية للمسلمين- المواريث".

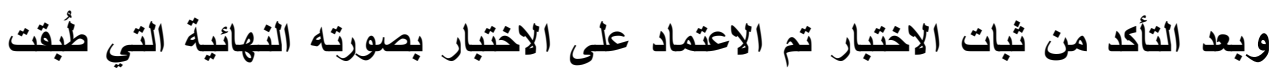
على عينة البحث. والشتملت هذه الصورة على ما يلي: 1- صفحة التعليمات: وهي تتضمن تعليمات الاختبار العامة التي توضح للطالبات المطلوب منهن بصورة محدة بقلر المستطاع.

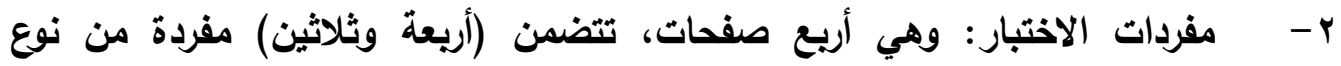
الاختيار من متعدد، والصواب والخطأ، حدد لكل مفردة منها تتم الإجابة عنها بشكل صحيح درجة واحدة فقط، ويذلك تصبح الدرجة العظمى للاختبار (أريعة وثلاثين) 
درجة، واللارجة الصغرى للاختبار (صفرًا). وقد وزعت هذه المفردات عشوائيًا للمفاهيم المراد قياسها على النحو الموضح في الجدول السابق. اعداد مفتاح تصحبح اختبار مفاهيم علم الفرائض:بعد إعداد الاختبار في صورته النهائية تم إعداد مفتاح لتصحيحه بحيث تم إعطاء كل إجابة صحيحة درجة وإحدة وكل إجابة خطأ صفر ويالتالي فإن النهاية العظمى للاختبار هي( ؟ ب) أربعة وثلاثين درجة.

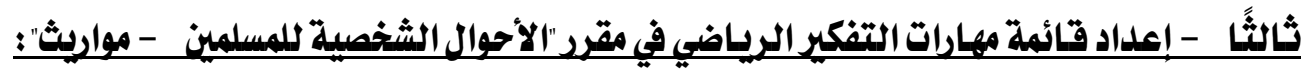
تم إعداد القائمة في ضوء الخطوات التالية: ج- الهـف من القائمة: التوصل إلى مهارات التفكير الرياضـي التلازمـة لطالبات الشريعة والقانون

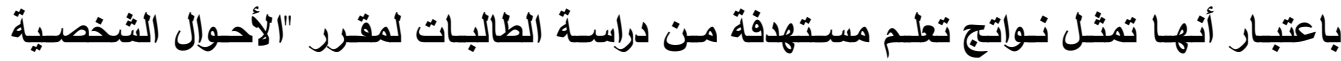

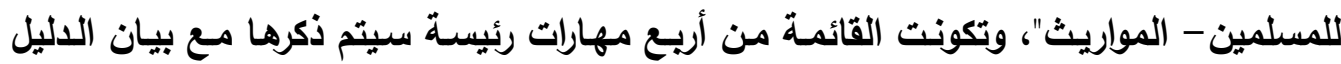
عليها من لائحة كلية الشريعة والقانون على النحو التالي: - - مهارة الاستقراء: ويؤكد ذلـك مـا حددته المعـيير القوميـة الأكاديميـة لمواصفات خـريج

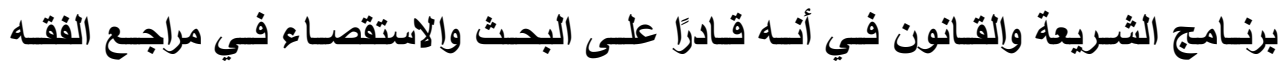
الإسلامي، وقادرًا على المقارنة والتحليل والترجيح وتكوين الرأي الفقهي الصحيح (الهيئة

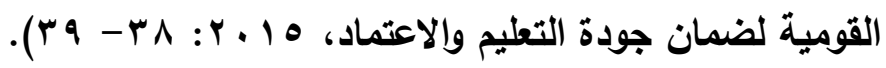
- مهارة الاستتناج: ويؤكد ذلك مـا حدده دليل كلية الشريعة والقـانون لمواصفات خريج برنامج الثريعة والقانون في أنسه يكون قادرًا على استنتاج الأحكام من كتاب الله تعالى

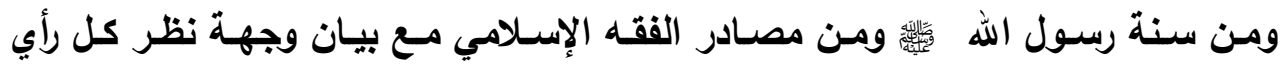

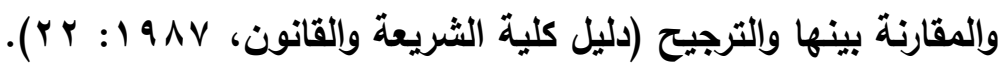
- - مهارة البرهـان الرياضـي: ويؤكد ذلك مـا حددته المعايير القوميـة الأكاديميـة لمواصفات خريج برنامج الشريعة والقانون في أن إكسـاب الطالب القدرة على تقديم الحكم الثرعي

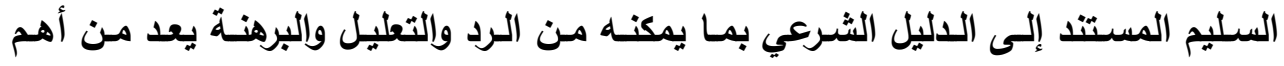

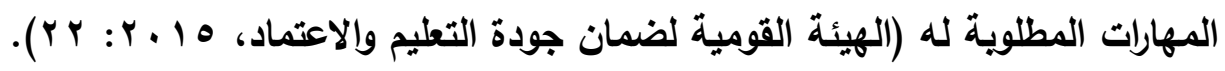
- - مهارة النمذجة: ويؤكد ذلك كما مـا حددته المعايير القومية الأكاديمية لمواصفات خريج برنامج الثريعة والقانون في أن الطالب يحتاج إلى المهارات التي تجعله يحول مـا حصله 
من معارف نظريـة إلى قدرات ومهارات تطبيقيـة عملية، تمكنهـه من توظيف معارفه في

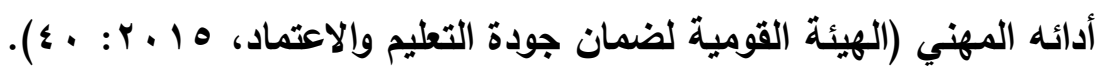
ب- مصادر بناء القائمة: الرجوع إلى بعض المصاده الهور منها:

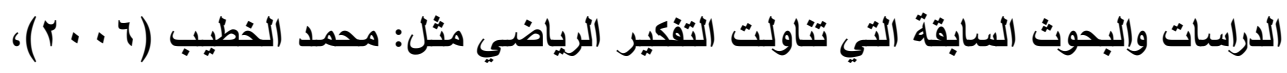

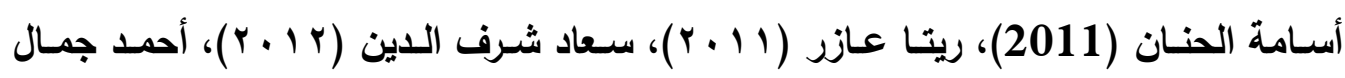

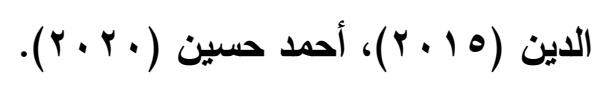

خ- الصورة الأولية للقائمة: تم تنظيم قائمة المهارات في أريع مهارات رئيسة وهي:

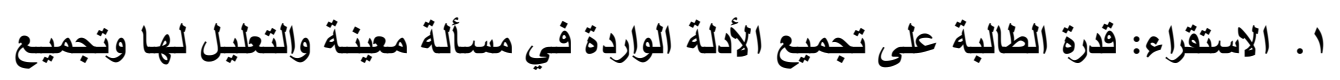

الآراء الواردة فيها واستخلاص الرأي الراجح.

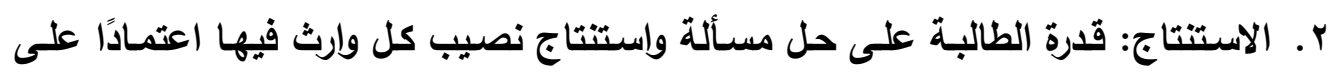

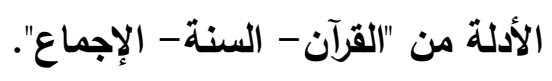

r. البرهان الرياضي: مجموعة من المهارات الفرعية التي تستدعي تدرب الطالبة عليها حتى الاجى تتمكن من حل مسائل علم الفرائض وتبدأ بالتخطيط ثم البناء ثم التقويم للبرهان، اعتمـادًا على الأدلة وإلتعليل للبرهان. ع. النمذجةة: قدرة الطالبـة على تمثيل بيانـات المسـائل في صورة جداول وتمثيل الحل في صورة أعمدة أو دوائر بيانية. دـ - عرض القائمة على السادة المحكمين من المتخصصين في تلدريس الفقه وأصولهه والفقه

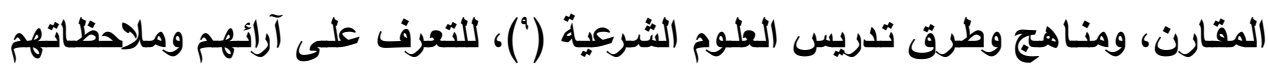

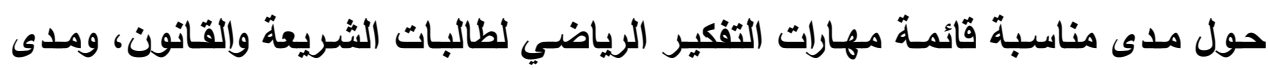

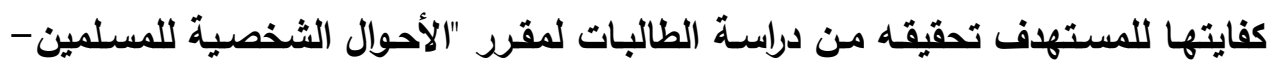

$$
\text { المواريث". }
$$

ذ- الصورة النهائية للقائمة: بعد الانتهاء من تعديلات المحكمين تم وضع الصورة النهائية

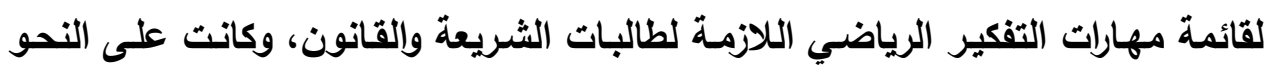
التالي: تذكر المهارات جميعها الرئيسة والفرعية هنا 


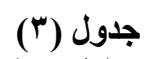

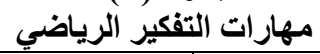

\begin{tabular}{|c|c|c|c|}
\hline مؤشرات أداء الطالبة للمهارة في مسائل مادة الفرايض & المهارات الفرعية & الرئيسة & $p$ \\
\hline 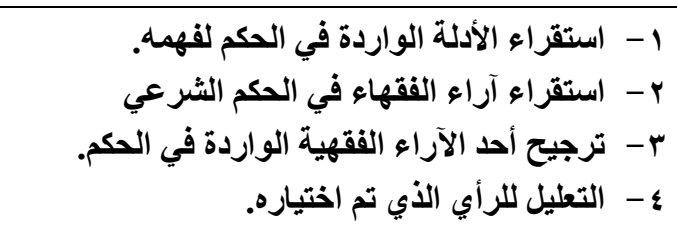 & لالاستلقرائي الفقهي & الاستقراء & .1 \\
\hline ه - الاستثهاد بالدليل على الحكم الفقهي في المسألة. & 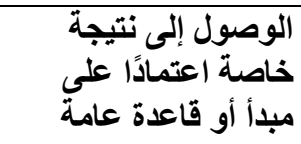 & الاستنتاج &.$r$ \\
\hline 1- - تحديد المطلوب في المسألة. & التخيطي للبرهان & البرياضي &.$r$ \\
\hline ه- - تربيب خطوات الحل بل الربل والمطوب. & والتعبير وصياغة البرهان & & \\
\hline 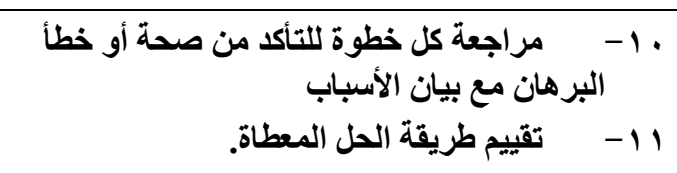 & التقويم للبر هان & & \\
\hline 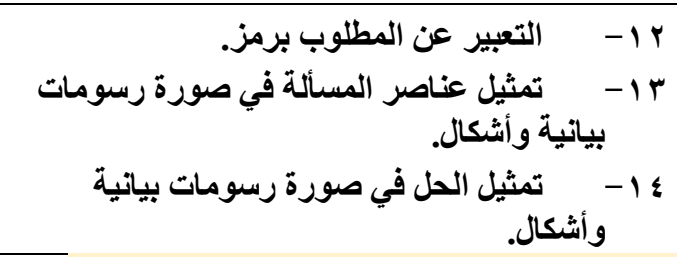 & التسبئلة بصور متعلداتدة في & النمذجة &.$\varepsilon$ \\
\hline
\end{tabular}

رابعًا - بنـاء اختبار مهارات التفكير الريـاض في مقرر "الأحوال الشخصية للمسلمين - المواريث" : هدف البحث الحالي إلى تنمية مهارات التفكير الرياضي لاى طالبات الثريعة والثانون؛ ولتحقيق هذا الهذف تم بناء الاختبار، وقد جاء الاختبار في صورته المبائية مكوناً من (ب ؛ ) مفردة من نوعي الاختيار من متعدد والتمثيل البياني بالرسم، ويعرضه على السادة المحكمين لإبداء الرأي بالحذف أو الإضافة والتعديل، ومن ثم إجراء التعديلات المطلوية، جاء الاختبار 
في صورته النهائية مكوناً من (• (ء) مفردة، وخصص لكل سؤال درجة وإحدة، ويذلك تكون

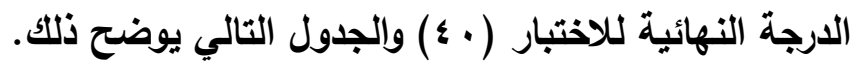
جدول (؛ ؛ )

يوضح جذول مواصفات اختبار مهارات التفكير الرياضي لطالبات الثريعة والقانون

\begin{tabular}{|c|c|c|c|}
\hline 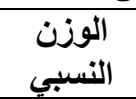 & المجموع & أرقام المفردات & أبعاد الاختبار \\
\hline$\%$ r. & $\Lambda$ & 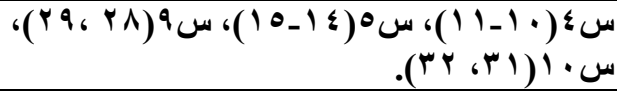 & الاستقراء \\
\hline$\%$ YV.o & 10 & 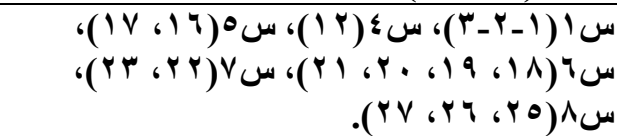 & الاستنتاج \\
\hline$\%$ ro & 1. & 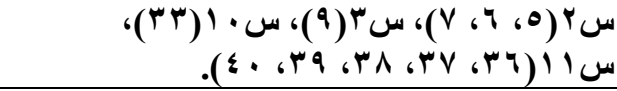 & 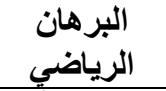 \\
\hline$\%$ \%.o & V & 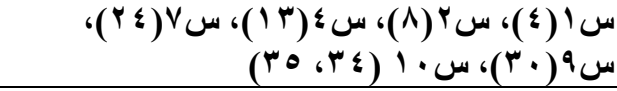 & النمذجة \\
\hline$\% 1 \ldots$ & $\varepsilon$. & & الإجمالي \\
\hline
\end{tabular}

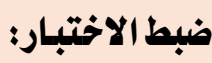

r- التجرية الاستطلاعية لاختبار مهارات التفكير الرياضي:

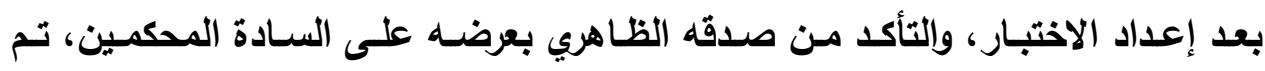

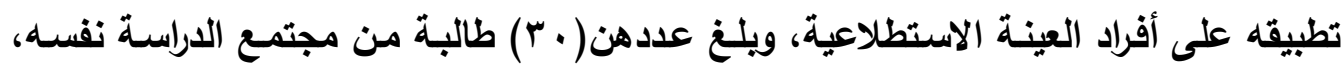

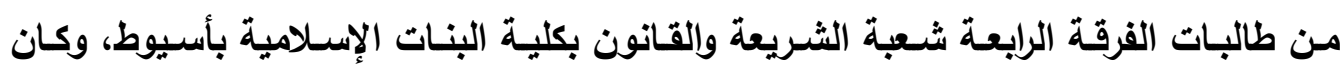
الهـف من تطبيق الاختبار على العينة الاستطلاعية محداً في النقاط الآتية: و - التأكد من وضوح التعليمات. ز - حساب زمن الإجابة عن الاختبار.

ح- حساب معاملات السهولة والصعوية ومعاملات التمييز لأسئلة الاختبار . ط-حساب الاتساق الداخلي للاختبار. ي-حساب ثبات الاختبار. ت- التأكد من وضوح التعليمات قبـل البدء في الإجابـة عن الاختبـار كـان هنـاك حرص على قراعة التعليمـات مـن قبـل الطالبـات، وتوضيح تلك التعليمـات، كي يتسـنى لهن الإجابـة عن مفردات الاختبار بطريقة سليمة، حيث تبين أن تعليمات الاختبار واضحة تماماً لجميع أفراد العينة الاستطلاعية. 
ث-زمن الإجابة عن الاختبار

تم حسـاب المتوسط الزمني الذي استغرقته جميع الطالبات في الإجابـة عن الاختبار

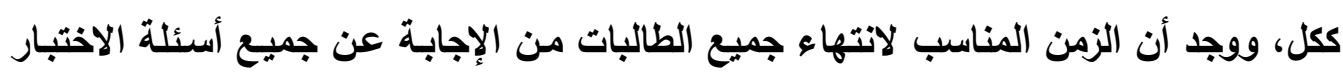
هو: ( • ( ) دقيقة؛ حيث تم حسابها من المعادلة التالية:

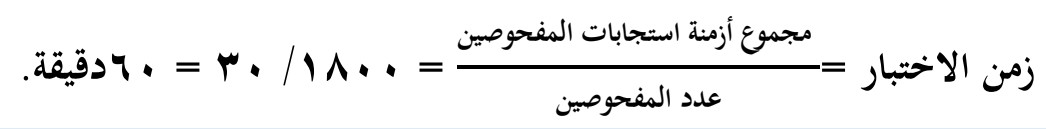

ح- حساب معاملات السهولة والصعوية والتمييز لأسئلة الاختبار تم حساب معاملات السهولة والصعوية لكل سؤال من أسئلة الاختبار باستخدام معادلتي

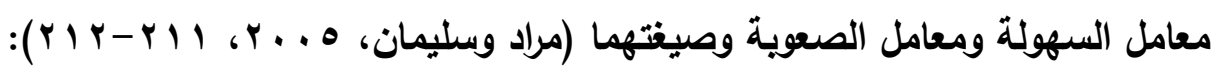

$$
\begin{aligned}
& \text { معامل السهولة } \\
& \text { معامل الصعوية = } 1 \text { - معامل السهولة } \\
& \text { ن = عدد أفراد العينة الاستطلاعية }
\end{aligned}
$$

مج ص = عدد الطالبات اللاتي أجبن إجابة صحيحة عن السؤال.

مج خ = عدد الطالبات اللاتي أجبن إجابة خاطئة عن السؤال.

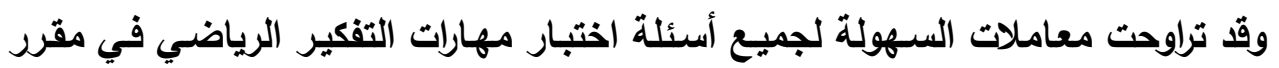

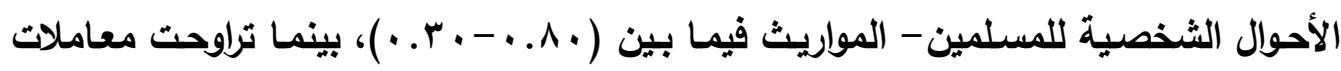

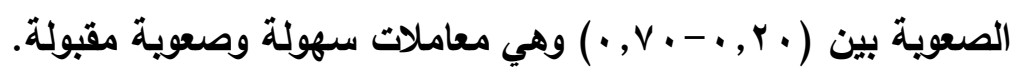

كما تم حساب معاملات التمييز لكل سؤال من أسئلة الاختبار باتباع الخطوات الآتية (مراد

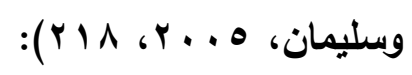

تم حساب عدد الإجابات الصحيحة عن السؤال الواحد في المجموعة العليا التي تضم أورلق

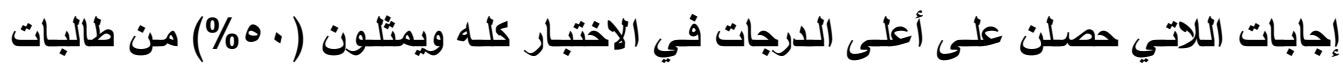
التجرية الاستطلاعية. تم حساب عدد الإجابات الصحيحة عن السؤال الواحد في المجموعة الدنيا التي تضم أورلق

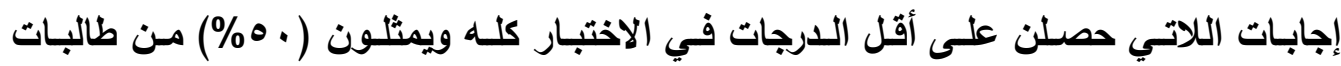
التجرية الاستطلاعية. 
تم الحصول على معامل التمييز بتطبيق المعادلة الآتية:

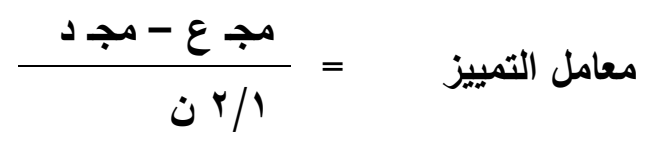

حيث مج ع = عدد طالبات المجموعة العليا اللاتي أجبن إجابة صحيحة عن السؤال.

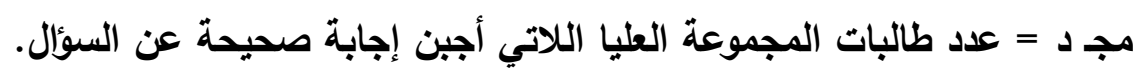
ن = مجموع الطالبات في المجموعتين.

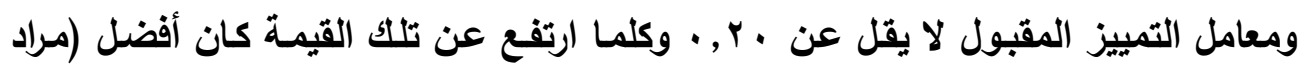

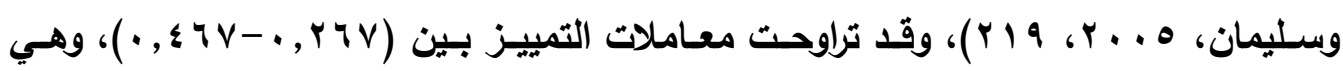

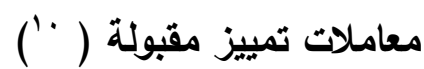
ر- سـاب الاتسـاق الــاخلي للاختبـار: يسـتخدم الاتسـاق الــاخلي لاسـتبعاد الأسـئلة غيـر

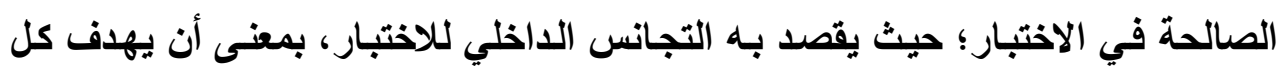

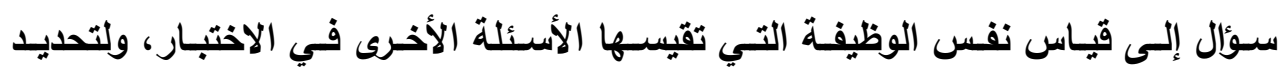
الاتسـاق الـاخلي تـم حسـاب معـاملات الارتبـاط بـين درجـة كل سـوأل والمجمـوع الكلي

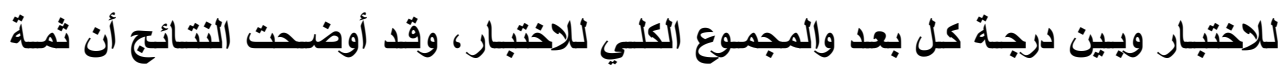

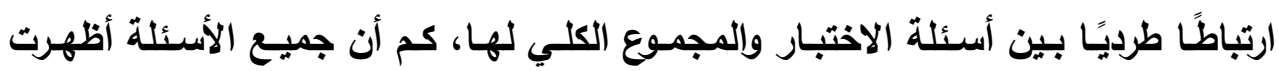

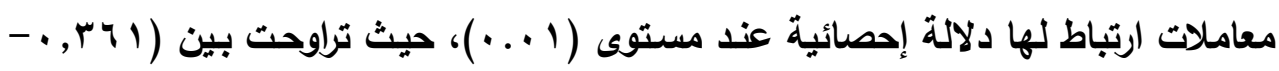

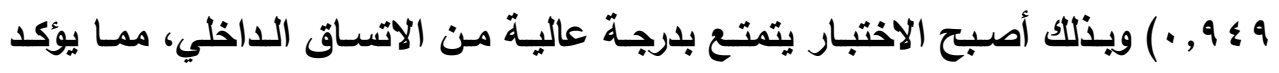

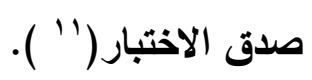

\section{جدول (ن)}

\begin{tabular}{|c|c|}
\hline معامل الارتباط & البعد البع \\
\hline$* * . .9 \vee 9$ & الاستثراء \\
\hline$* * .911$ & الاستنتاج \\
\hline$* * .991$ & لبر هان الرياضي \\
\hline$* * .985$ & النمذجة \\
\hline
\end{tabular}

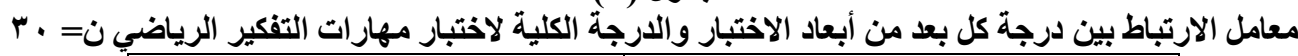

“' ملحق( • (1) معاملات السهولة والصعوبة والتمييز لاختبار مهارات التفكير الرياضي.

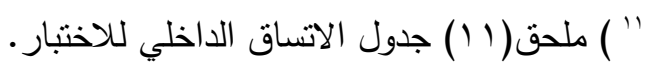


يتضـح من الجدول (ه) أن ثمـة ارتباطًا طرديًا ببين مجموع كل بعد من أبعاد الاختبار والمجموع الكلي لاختبار مهارات التفكير الرياضي، كما يتضح من الجدول (•) أن جميع أبعاد

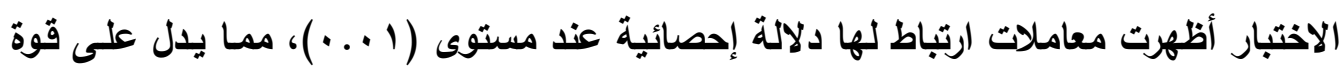

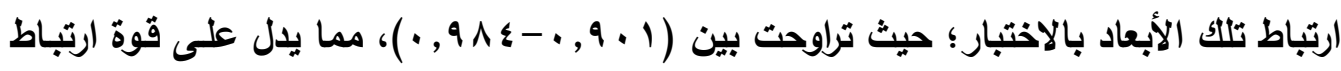

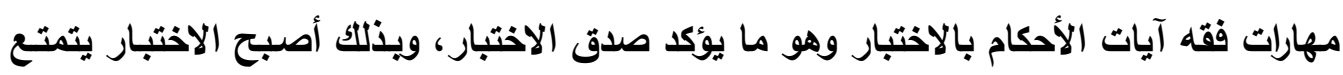
بارجة عالية من الاتساق الاخلي. هـ - حساب ثبات الاختبار : بعد تطبيق اختبار مهارات التفكير الرياضي على طالبات العينة

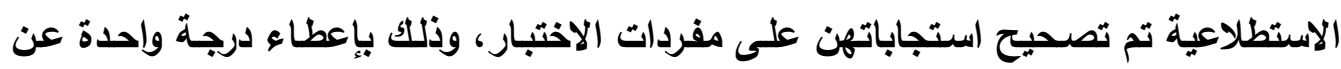
كل إجابة صحيحة، وصفر عن كل إجابة خطأ، وتم حساب ثبات الاختبار، حيث يقصد بالثبات

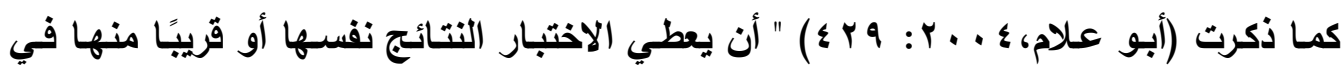

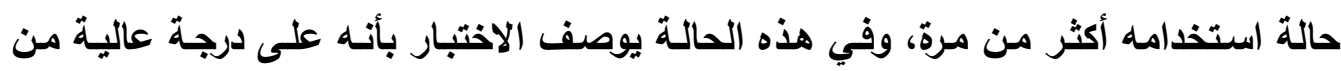

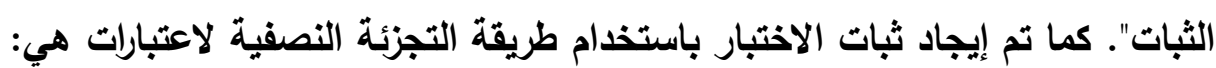
- - معوية توافر الصيغ المتكافئة للاختبار. - قد يتعذر وجود نفس الأفراد لإعادة تطبيق الاختبار عليهم مرة ثانية.

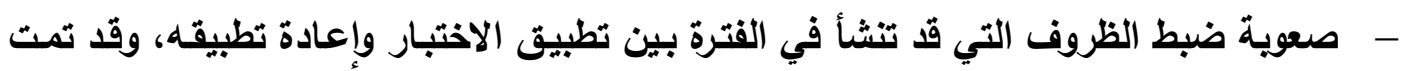
تجزئة مفردات اختبار مهارات فقه آيات الأحكام إلى جزأين:

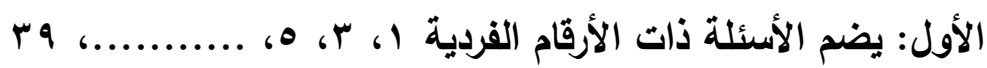

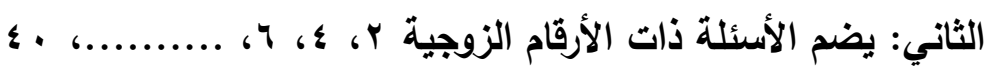

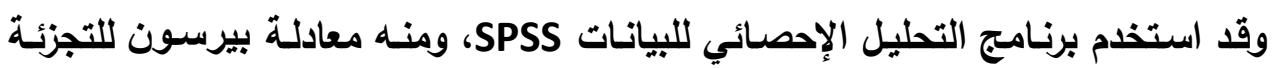
النصفية كالتالي:

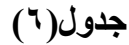

معامل ثبات اختبار مهارات التفكير الرياضي بطريقة التجزئة النصفية " لبيرسون “،لى العينة الاستطلاعية r.

\begin{tabular}{|c|c|c|c|}
\hline \multicolumn{2}{|c|}{ التجزئة النصفية } & & \multirow[b]{2}{*}{ الأسئلة } \\
\hline 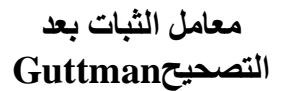 & الارتباط بين نصفى الاختبار & & \\
\hline \multirow{2}{*}{.99} & \multirow{2}{*}{.911} & $r$. & الأسئلة الفردية \\
\hline & & $r$. & الأسئلة الزوجية \\
\hline
\end{tabular}




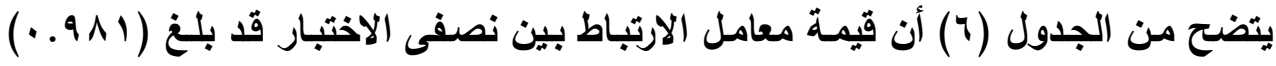
كبيرة، ؛ كمـا بلـغ معامل الثبات بعد التصحيح لGuttman (99 . . ) ممـا يشير إلى الثبات

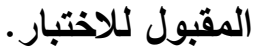

الاختبار في صورته النهائبة|("): بعد الانتهاء من تعديلات المحكمين ومراجعة مفردات الاختبار بهاف التأكلد من خلوها من التعقيد في المعنى، أو التداخل فيما بينها الذي قد يُؤثر في تحقيق الهدف من الاختبار . في ضوء ما أسفرت عنه آراء ومقترحات لجنة التحكيم تكون الاختبار من (أربعين) سؤالا، بحيث يقيس كل سؤال من أسئلة الاختبار مهارة من المهارات التدريسية، بحيث تفطي هذه الأسئلة في مجملها مهارات التفكير الرياضسي المتضمنة في هي هني المقرر الدراسي: "الأحوال الشخصية للمسلمين - المواريث". وبعد التأكد من صدق وثبات الاختبار تم الاعتماد على الاختبار بصورته التهائية التي طُبقت على عينة البحث. واشتملت هذه الصورة على ما يلي: 1 - صفحة التعليمات: وهي تتضمن تعليمات الاختبار العامة التي توضح للطالبات المطلوب منهن بصورة محددة بقدر المستطاع. r- مفردات الاختبار: وهي أربع صفحات، تتضمن (أربعين) مفردة من نوع الاختيار من متعدد، التمثيل بالرسم البياني، حدد لكل مفردة منها تتم الإجابة عنها بشكل صحيح درجة التهن واحدة فقط، ويذلك تصبح الدرجة العظى للاختبار (أربعين) درجة، واللارجة الصغرى للاختبار (صفرًا). وقا وزعت هذه المفردات عشوائيًا للمهارات المراد قياسها على النحو التالي: - مفردات مستوى الاستقراء: وعددها (ثمان) مفردات. - مفردات مستوى الاستنتاج: وعددها (خمس عشرة) مفردة. - مفردات مستوى البرهان الرياضي: وعددها (عشر) مفردات. - مفردات مستوى النمذجة: وعددها (سبع) مفردات. ويمكن النظر إلى أرقام الأسئلة في اختبار مهارات التفكير الرياضي - تبعًا لمستويات المهارات - بالنظر إلى جدول (r) سابق الأكر، وق بلغت الدرجة العظمى للاختبار (أريعون) 


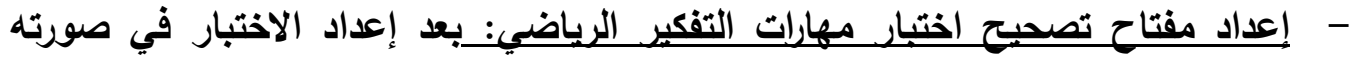
النهائية تم إعداد مفتاح لتصحيحه بحيث تم إعطاء كل إجابة صحيحة درجة واحدة وكل إجابة خطأ صفر ويالتالي فإن النهاية العظمى للاختبار هي( • ـ ؛ أريعون درجة. خامسًا - إعداد دليل عضو هيئة التدريس للتدريس وفق إستراتيجية دائرة التعلم الملدعومة

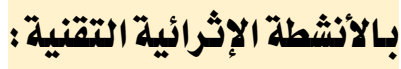

تم بناء دليل التدريس الجامعي وفق إستراتيجية دائرة التعلم المدعومـة بالأنشطة الإثرائية

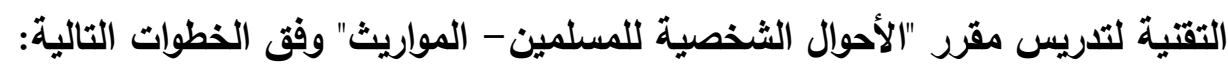
أ- الهـف من الدليل: تمثل الهدف من دليل التدريس في مسـاعدة أعضـاء هيئة التدريس

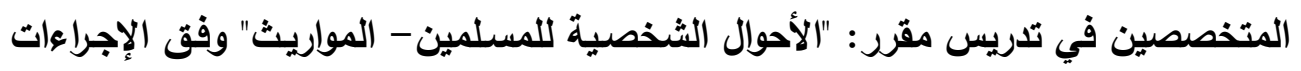

التدريسية المحددة في إستراتيجية دائرة التعلم المدعومة بالأنشطة الإثرائية التقتية.

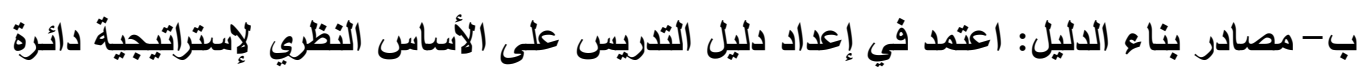

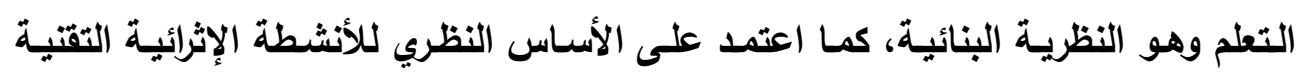

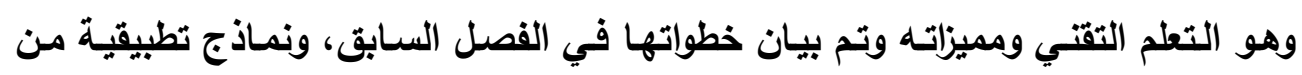

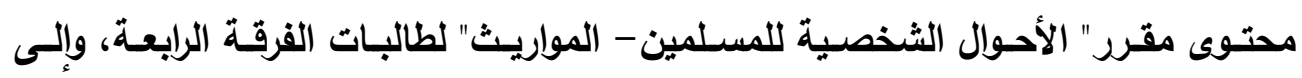
الإطار النظري للبحث، للاستفادة منه في إعداد الاليل.

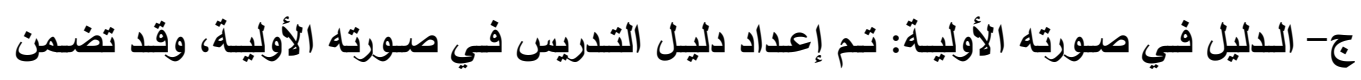
المكونات التالية: - مقدمة توضح فيها الباحثة بعض المفاهيم الضرورية لاستخدام الدليل مثل: إستراتيجية

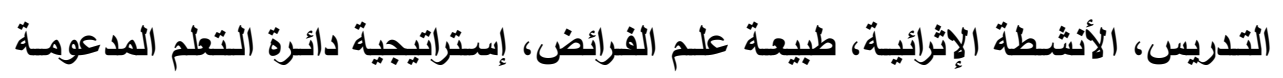
بالأنشطة الإثرائية التقنية. - عرض الخريطة الزمنية لتنفيذ موضوعات الدليل: حيث تم وضع الخريطة الزمنية لتنفيذ الموضوعات للاسترشاد بها أثناء التدريس. - تحديد الأسـاليب المستخدمة باللاليل: إرشاد عضو هيئة التدريس لبعض الأسـاليب التي

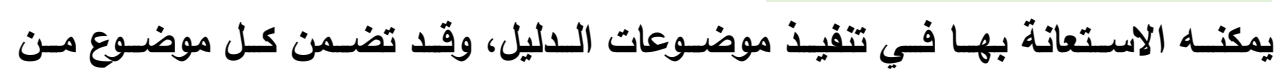
الموضوعات المراحل الإرشادية التالية: 
* عنوان الموضوع

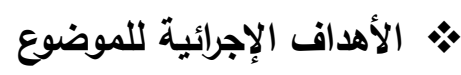

• • إجراءات السير في الموضوع وفق الإستراتيجية وتشـل: التهيئة للموضوع - اكتشـاف

$$
\text { المفهوم - تقديم المفهوم - تطبيق المفهوم - التقويم. }
$$

• الأنشطة الإثرائية التقتية: وقد تم دمجها في كل خطوة من خطوات الإستراتيجية داخل

دليل التدريس.

- توجيهات لاستخدام الدليل: قدم الدليل لعضو هيئة التدريس بعض التوجيهات الإرشـادية لاستخدام الاليل.

$$
\text { - الأساليب الإحصائية. }
$$

تـم اسـتخدم برنـامج التحليـل الإحصـائي للبيانـات SPSS، ومنــهـ الأســاليب الإحصـائية

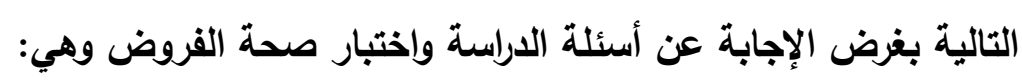

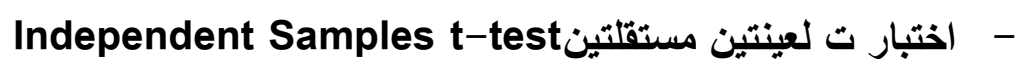

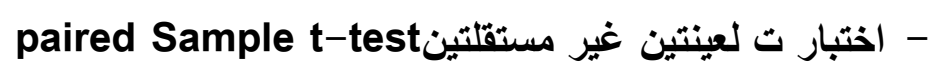
- مربع إيتا2 ضبط تكافؤ المجموعتين (التجريبية- الضابطة) باستخدام اختبار (ت) لتوضيح الفروق بين مجموعتي البحث التجريبية والضابطة في القياس القبلي لاختبار مفاهيم علم الفرائض: لتعرّف تكافؤ المجموعتين التجريبية والضابطة، والحصول على المعلومات القبلية التي تساعد في العمليات الإحصائية الخاصة بنتائج البحث، تم تطبيق أداة البحث (اختبار

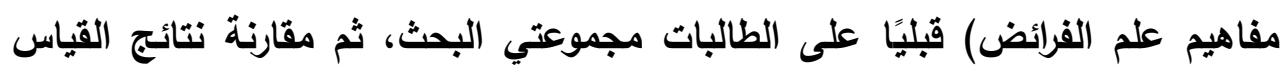

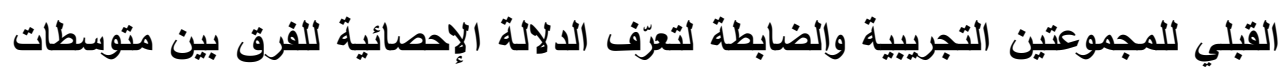
درجات أفراد المجموعتين، وذلك باستخدام اختبار (ت)، وكانت نتائج القياس القبلي لتئي للمجموعتين كما في الجدول(؟). 
(v) جدول)

المتوسطات والانحرافات المعيارية وقيم " ت " ومستوى الدلالة الإحصائية للفروق بين متوسطات درجات مجموعتي البحث التجريبية والضابطة في القياس القبلي لاختبار مفاهيم علم الفرائض لطالبات الاتبات الشريعة

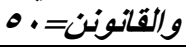

\begin{tabular}{|c|c|c|c|c|c|c|}
\hline الدلالة (Sig) & قيمة (ت) & الحرية & الانحراف المعياري & المتوسط & المجموعة & أبعاد الاختبار \\
\hline \multirow{2}{*}{ غير دالة } & \multirow[t]{2}{*}{$\because \leqslant 1 V$} & \multirow{2}{*}{$9 \wedge$} & $\because V Y \wedge$ & 1 & التجريبية & \multirow[t]{2}{*}{ الإرث بالفرض } \\
\hline & & &.$V 1 Y$ & $.9 \leq$. & الضابطة & \\
\hline.$\wedge 07$ & \multirow[t]{2}{*}{$. .111-$} & \multirow[t]{2}{*}{91} & .040 & $\because 7 \ldots$ & التجريبية & \multirow[t]{2}{*}{ الإرث بالتعصيب } \\
\hline غير دالة & & & $.07 V$ & $.7 r$. & الضابطة & \\
\hline \multirow{2}{*}{ غير دالة } & \multirow{2}{*}{1.101.} & \multirow[t]{2}{*}{$9 \wedge$} & $\because \varepsilon \cdot \varepsilon$ & . Y.. & التجريبية & \multirow[t]{2}{*}{ العصبة النسبية } \\
\hline & & &.$\leq 7 \pi$ & $\cdot r \ldots$ & الضابطة & \\
\hline \multirow{2}{*}{ غير دالة } & \multirow{2}{*}{$.00 r$} & \multirow[t]{2}{*}{$9 \wedge$} & $.0 \leq \varepsilon$ & $\because \Delta Y$. & التجريبية & \multirow[t]{2}{*}{ العاصب بالنفس } \\
\hline & & & $\because 0 \leq r$ &..$\leqslant 7$. & الضابطة & \\
\hline \multirow{2}{*}{ غير دالة } & \multirow{2}{*}{$\because 1 \wedge \varepsilon_{-}$} & \multirow[t]{2}{*}{$9 \wedge$} & $.0 \leq \leqslant$ & $.0 \ldots$ & التجريبية & \multirow[t]{2}{*}{ العاصب بغيره } \\
\hline & & & $\because 0 \leq \leq$ & $\because O Y$. & الضابطة & \\
\hline \multirow{2}{*}{ غير دالة } & \multirow{2}{*}{$.9 r r$} & \multirow[t]{2}{*}{$9 \wedge$} & $.0 \leq 1$ & .07. & التجريبية & \multirow[t]{2}{*}{ العاصب مع غيره } \\
\hline & & & $\because 0 \leqslant Y$ & $\because \leqslant 7$ & الضابطة & \\
\hline \multirow{2}{*}{ غير دالة 1 أة } & \multirow{2}{*}{ ב.r. } & \multirow[t]{2}{*}{91} & •.rYA &. $.1 \%$ & التجريبية & \multirow[t]{2}{*}{ الميراث بوصفين } \\
\hline & & & $\because \leqslant 11$ &.$Y Y \cdot$ & الضابطة & \\
\hline \multirow{2}{*}{ غير دالة } & \multirow{2}{*}{1.110.} & 91 & $\because r \wedge \wedge$ & $\because 11$. & التجريبية & الحجب \\
\hline & & & $\because \leqslant 0 \leqslant$ & $\because Y \wedge$. & الضابطة & \\
\hline$\because \wedge 0 \leq$ & $-1 \wedge \varepsilon$ & 91 & $\because 0 \leq \leqslant$ & $\because 0 \ldots$ & التجريبية & حجب النقصان \\
\hline غير دالة & 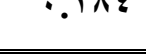 & & $\because 0 \leq \leqslant$ & $\because \leqslant \Lambda$. & الضابطة & \\
\hline$\because \varepsilon 7 r$ & 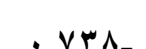 & 91 & $\because 0 \leq \leqslant$ &..$\leqslant \wedge$. & التجريبية & حجب الحرمان \\
\hline غير دالة & . & & $.0 \leq 1$ & .04. & الضابطة & \\
\hline$\because V 1 \leq$ & . " m & 91 & $\because 0 \leq \leqslant$ & $\because \leqslant \Lambda$. & التجريبية & الحواشي \\
\hline غير دالة & . & & $\because 0 \leq \leqslant$ & $.0 Y$. & الضابطة & \\
\hline$\because \wedge 0 \leqslant$ & $.11 \varepsilon$ & 91 & $.0 \leq \leq$ & $\because 0 \ldots$ & التجريبية & أصل المسألة \\
\hline غير دالة & $\because 112$ & & $.0 \leq \leq$ & $\because \leqslant \Lambda$. & الضابطة & \\
\hline$\cdot \wedge 0 \leq$ & & $9 \wedge$ & $.0 \leq \leqslant$ & $\because \leqslant \Lambda$. & التجريبية & تصحيح المسألة \\
\hline غير دالة & $\because 1 \times z=$ & & $.0 \leq \leqslant$ & $\because 0 \ldots$ & الضابطة & \\
\hline$\because \wedge 0 \leq$ & - $11 \leqslant$ & 91 & $\because 0 \leq \leqslant$ & $\because 0 \ldots$ & التجريبية & العول \\
\hline غير دالة & . & & $\because 0 \leq \leqslant$ & $\because \leqslant \Lambda$. & الضابطة & \\
\hline$\because \wedge 0 \leq$ & . 1 & 91 & $\because 0 \leq \leqslant$ & $\because 0 \ldots$ & التجريبية & الكلالة \\
\hline غير دالة & . & & $\because 0 \leq \varepsilon$ & $\because O Y$. & الضابطة & \\
\hline$\because \wedge 0 \%$ & $.1 \wedge 7_{-}$ & $9 \wedge$ & 0.199 & V.IY. & التجريبية & \\
\hline غير دالة & $.1 \times 1=$ & & 0.917 & V.r $\varepsilon$. & الضابطة & \\
\hline
\end{tabular}

باستقراء التتائج المعروضـة بالجدول (V) اتضع عدم وجود فرق دال إحصـائياً عند مستوى (ه . , • $\alpha$ ) بين متوسط درجاث الطالبات مجموعة البحث التجريبية في التطبيق 
القبلي، ومتوسط درجات مجموعة البحث الضابطة في التطبيق القبلي على اختبار مفاهيم علم

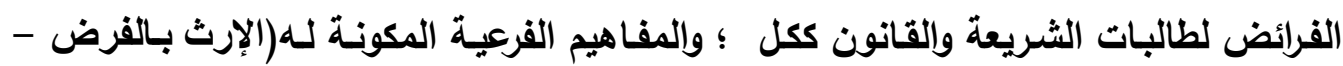

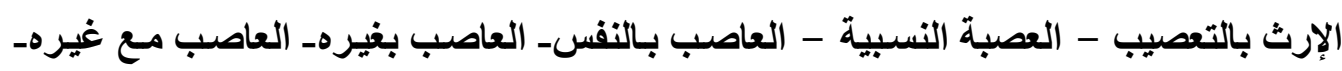
الميراث بوصفين- الحجب- حجب النقصان- حجب الحرمان- الحواشي- أصل المسـألةـ تصحيح

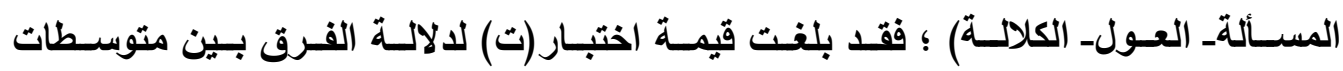

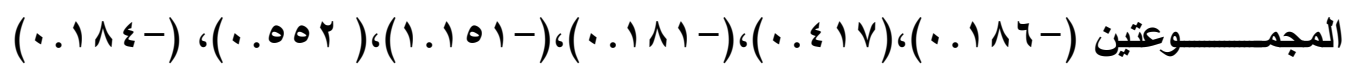

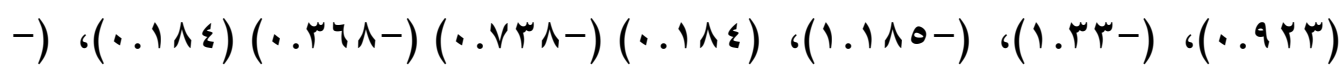

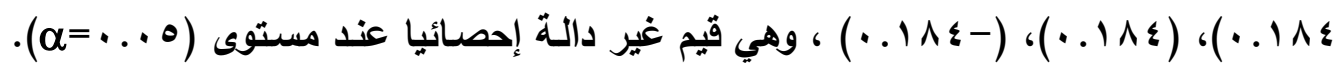
ويؤكد ذلك على تكافؤ مجموعتي البحث. • اختبار صحة الفرض الأول: والذي نص على ملى "وجود فرق ذو دلائة إحصائية بين متوسطي درجات طالبات المجموعة التجريبية في التطبيقين القبلي والبعدي لاختبار مفاهيم علم الفرائض لصالح التطبيق البعدي". اختبار (ت) لتوضيح الفروق بين التطبيقين القبلي والبعدي لاختبار مفاهيم علم الفرائض: 
(^) جدول) (1)

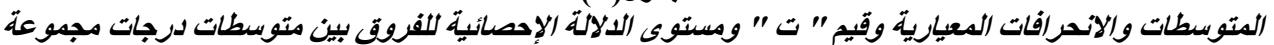

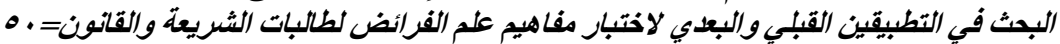

\begin{tabular}{|c|c|c|c|c|c|c|}
\hline الدلالة (Sig) & قيمة (ت) & الحرية & المعياري & المتوسط & التطبيق & أبعاد الاختبار \\
\hline \multirow{2}{*}{ '...' } & \multirow[t]{2}{*}{ IV.ArI- } & \multirow{2}{*}{$\leqslant 9$} & 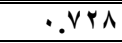 & 1 & قبلي & \multirow{2}{*}{ الإرث بالفرض } \\
\hline & & & 1.100 & $\varepsilon .79$. & بعدي & \\
\hline \multirow{2}{*}{ '⿳亠口冋' } & \multirow[t]{2}{*}{ 10.YVO } & \multirow{2}{*}{$\leqslant 9$} & .040 &. .7 & قبلي & \multirow[t]{2}{*}{ الإرث بالتعصيب } \\
\hline & & & .007 & $r .7$ & بعدي & \\
\hline \multirow{2}{*}{ 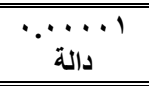 } & \multirow[t]{2}{*}{ 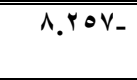 } & \multirow{2}{*}{$\leqslant 9$} & 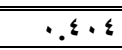 & $\because . r \ldots$ & قبلي & \multirow[t]{2}{*}{ العصبة النسبية } \\
\hline & & &.$r V$. & $\therefore \wedge \leqslant$. & بعدي & \\
\hline \multirow{2}{*}{$\begin{array}{l} \\
\end{array}$} & \multirow[t]{2}{*}{$1 \leqslant . \leqslant 1-$} & \multirow{2}{*}{$\leq 9$} & $.0 \leq \leqslant$ & $\because \Delta Y$. & قبلي & \multirow[t]{2}{*}{ العاصب بالنفس } \\
\hline & & & $\because r \wedge \theta$ & $1 . \wedge \Lambda$. & بعدي & \\
\hline \multirow{2}{*}{ دالة' } & \multirow[t]{2}{*}{$1 \cdot .9 \cdot 0-$} & \multirow{2}{*}{$\leq 9$} & $.0 \leqslant \leqslant$ & $.0 \ldots$ & قبلي & \multirow[t]{2}{*}{ العاصب بغيره } \\
\hline & & & .019 & 1.74. & بعدي & \\
\hline \multirow{2}{*}{ 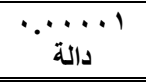 } & \multirow[t]{2}{*}{ 1..^9 - } & \multirow{2}{*}{$\varepsilon 9$} & $. .0 \leqslant 1$ &. .07. & قبلي & \multirow{2}{*}{ العاصب مع } \\
\hline & & & .0 .0 & $1.2 \ldots$ & بعدي & \\
\hline \multirow{2}{*}{ دالة' } & \multirow{2}{*}{$1 \cdot . r \wedge \Lambda_{-}$} & \multirow{2}{*}{$\leqslant 9$} & 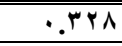 & $\because .1 Y$. & قبلي & \multirow{2}{*}{ بوصفين الميراث } \\
\hline & & & $\cdot . r V$. & $\cdot . \wedge \leqslant$. & بعدي & \\
\hline \multirow{2}{*}{ 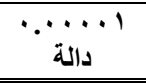 } & & $\varepsilon q$ & $\because . r \wedge \wedge$ & $\because 11$. & قبلي & الحجب \\
\hline & V.ATO- & 24 & 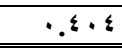 & $\because \wedge \ldots$ & بعدي & \\
\hline$\because \cdots \cdots 1$ & & & $.0 \leqslant \leqslant$ & $\because .0 \ldots$ & قبلي & حجب النقصان \\
\hline دالة & $17.121-$ & 29 & $\because v \leqslant 9$ & Y.T & بعدي & \\
\hline & & & $\because 0 \leq \leqslant$ & 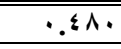 & قَبلي & حجب الحرمان \\
\hline 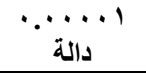 & $9.940-$ & $\leqslant 9$ & $\cdot .7 \cdot r$ & 1.74. & بعدي & \\
\hline & & & $.0 \leqslant \leqslant$ &..$\leqslant \Lambda$. & قبلي & الحواشي \\
\hline 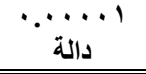 & $9.970-$ & $\leq 9$ & $\cdot . r+r$ & 1.74. & بعدي & \\
\hline$\because \cdots 1$ & $11.1 \wedge r_{-}$ & $\varepsilon q$ & $.0 \leq \leqslant$ & $.0 \ldots$ & قبلي & أصل المسألة \\
\hline دالة & - & 27 & .070 & $1 . V \leq$. & بعدي & \\
\hline$\because \cdots \cdots 1$ & $y \quad y \circ 0_{-}$ & $\leqslant 9$ & $.0 \leqslant \leqslant$ & $\because \leqslant \Lambda$. & قُبلي & تصحيح المسألة \\
\hline دالة & v. & & .749 & $1.2 \ldots$ & بعدي & \\
\hline$\because \cdots \cdots 1$ & 1. $94 .-$ & $\leqslant 9$ & $\because 0 \leqslant \leqslant$ & $\because 0 \ldots$ & قبلي & العول \\
\hline دالة & $19.910-$ & 29 & $\because .0 \mathrm{Vr}$ & $1 . V Y$. & بعدي & \\
\hline$\because \cdots \cdots 1$ & $191 \% \Lambda_{-}$ & $\leqslant 9$ & $.0 \leqslant \leqslant$ & $\because 0 \ldots$ & قُبلي & الكلالة \\
\hline دالة & 1. & & $\therefore$ VOr & T.TY. & بعدي & \\
\hline$\because \cdots \cdots 1$ & $I V \leqslant Y Y_{-}$ & $\leqslant 9$ & 0.199 & V.IY. & قبلي & المحمو ع \\
\hline دالة & 18.6 & & $8.5 \times 0$ & $r \wedge . r \leqslant$. & بعدي & المجموع \\
\hline
\end{tabular}

باستقراء النتائج المعروضة بالجدول (^) اتضح وجود فرق دال إحصائياً عند مستوى (ه ., .

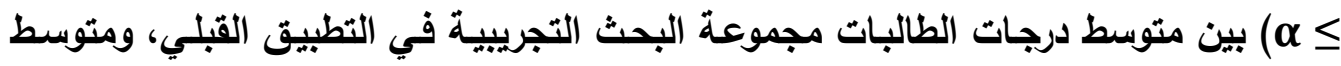
درجاتهم في التطبيق البعدي على اختبار مفاهيم علم الفرائض لطالبات الثريعة والقانون ككل ؛ والمفـاهيم الفرعيـة المكونـة لـه(الإرث بـالفرض - الإرث بالتعصسيب - العصبة النسـبية العاصـب بـالنفس- العاصـب بغيرهـ العاصـب مـع غيرهـ الميـراث بوصـفين- الحجبــ حجب البـ 
النقصان- حجب الحرمان- الحواشـي- أصل المسـألة_ تصحيح المسـألة_ العول- الكلالـة) ؛ فقد

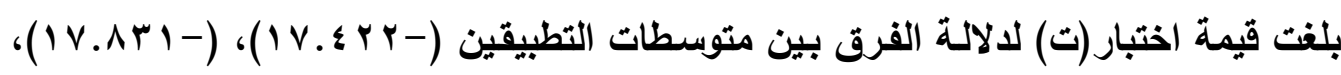

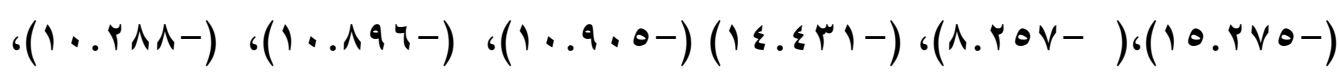

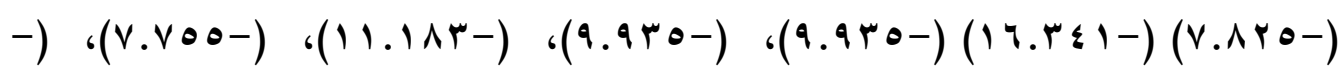

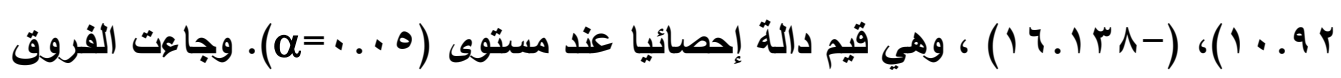
لصالح التطبيق البعدي. حجم التأثير لإستراتيجية دائرة التعلم المدعومة بالأنثطة الإثرائية التقتية في تنمية مفاهيم علم الفرائض لطالبات الثريعة والقانون لاى مجموعة البحث التجريبية جدول(9)

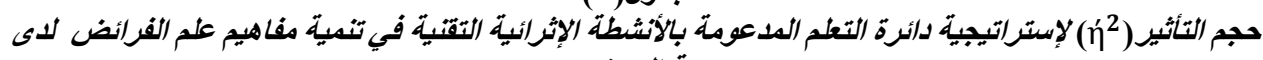
مجموعة البحث ن=.

\begin{tabular}{|c|c|c|c|c|}
\hline مستوى حجم الأثر & مريع إيتا ( 2 †) & قيمة " ت " & ح.د & المفهوم \\
\hline كبيز &.$\vee V 7 \varepsilon$ & $|V . \wedge r|-$ & $\leqslant 9$ & الإرث بالفرض \\
\hline كبير & $\cdot v \cdot \varepsilon$ & lo.rvo_ & $\varepsilon 9$ & الإرث بالتعصيب \\
\hline كبير &..$\leqslant 1$ & $\Lambda_{.}$rov- & $\varepsilon q$ & العصبة النسبية \\
\hline كبير & .71. & $1 \leqslant . \leqslant r_{-}$ & $\varepsilon 9$ & العاصب بالنفس \\
\hline كبير & $.0 \leqslant 1$ & $1 \cdot .9 \cdot 0_{-}$ & $\leqslant 9$ & العاصب بغيره \\
\hline كبير & $\cdot .0 \leqslant 1$ & $1 \cdot . \wedge 97$ & $\varepsilon q$ & العاصب ميره \\
\hline كبير & .019 & $1 \cdot . r \wedge \Lambda_{-}$ & $\leq 9$ & لميراث بوصفين \\
\hline كبير & $\cdot r \wedge 0$ & V.AYO_ & $\leqslant 9$ & الحجب \\
\hline كبير &.$V T r$ & $17 . r \leqslant 1$. & $\varepsilon 9$ & حجب النقصان \\
\hline كبير & $.0 . r$ & 9.940 & $\leqslant 9$ & حجب الحرمان \\
\hline كبير & $.0 . r$ & 9.940 & $\leqslant q$ & الحو اشي \\
\hline كبير & .071 & $11.1 \wedge r_{-}$ & $\leqslant 9$ & أصل المسألة \\
\hline كبير & $\cdot r \Lambda$. & v.V०० & $\leqslant 9$ & تصحيح المسألة \\
\hline كبير & $.0 \leqslant 9$ & $1 . .94 \cdot-$ & $\leqslant 9$ & العول \\
\hline كبير &.$V Y V$ & $18.1 \% \Lambda_{-}$ & $\varepsilon q$ & الكلالة \\
\hline كبير & $\because \vee 04$ & IV.EYY- & $\leqslant 9$ & الاختبار ككل \\
\hline
\end{tabular}

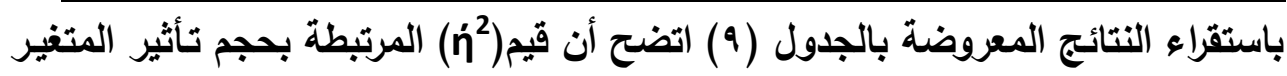

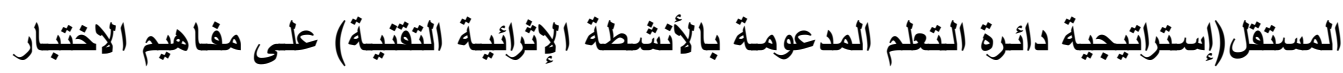

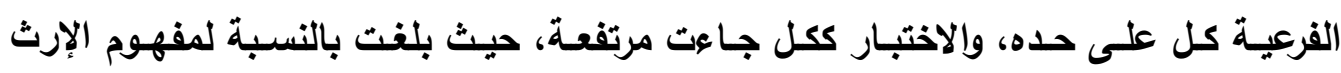

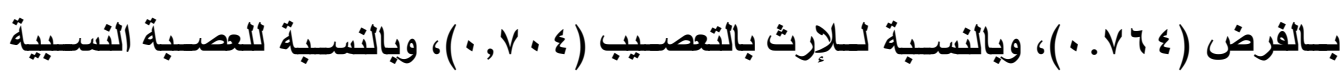




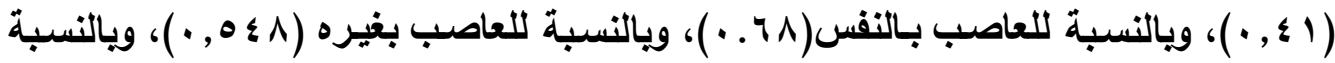

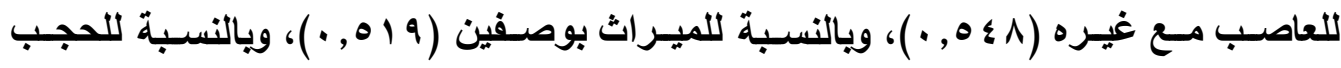

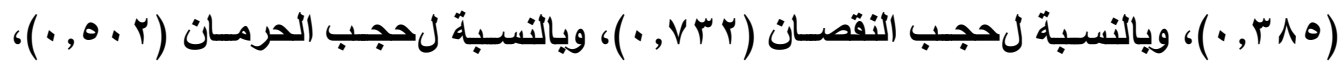

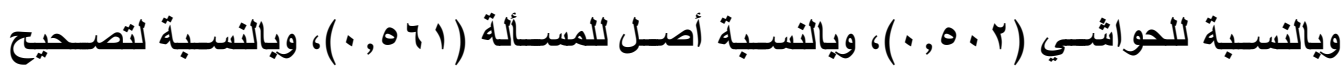

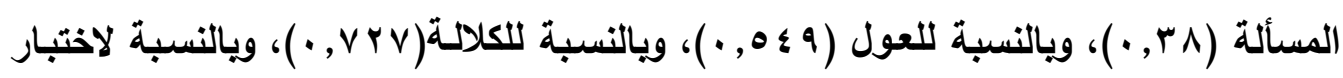

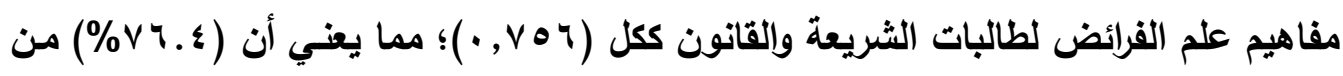

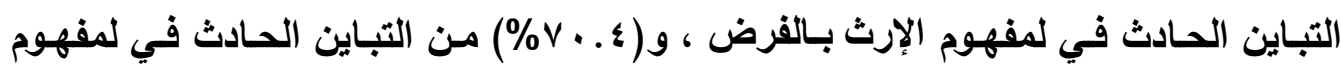

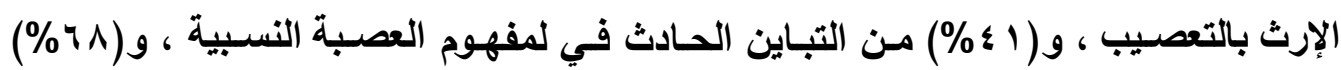

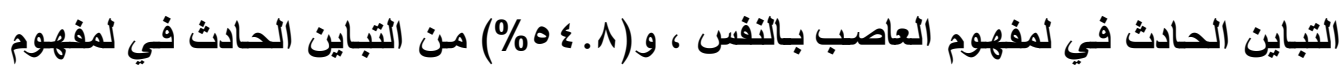

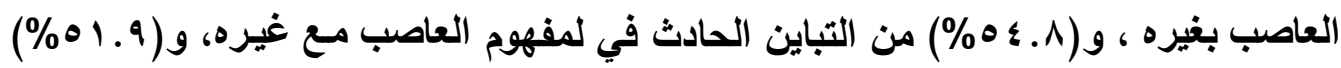

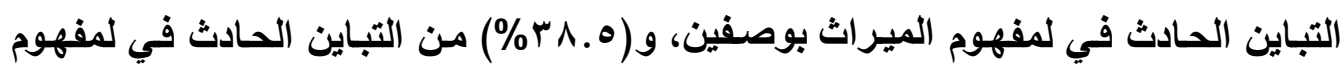

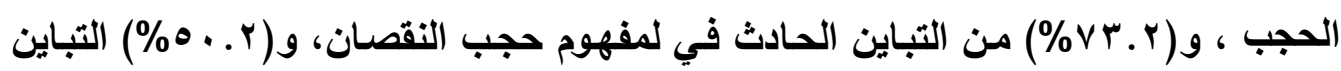

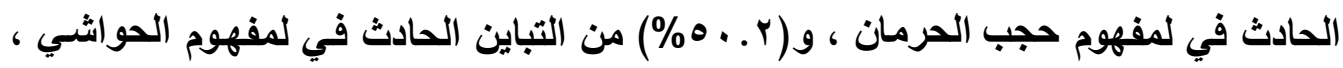

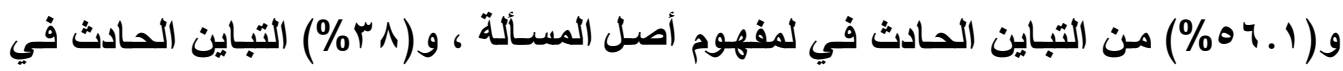

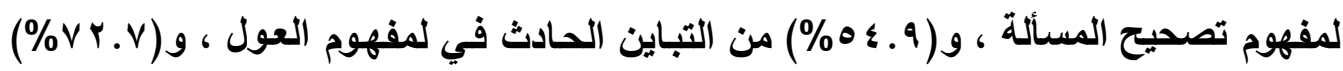

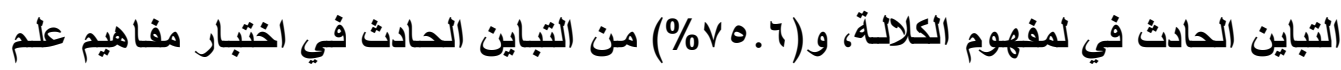
الفرائض لطالبات الثريعة والقانون ككل ، ترجع جميعها إلى المتغير المستقل(إستراتيجية دائرة التعلم المدعومة بالأنشطة الإثرائية التقتية). • اختبار صحة الفرض الثاني: والذي نص على: "وجود فرق ذو دلالة إحصائية بين متوسطي درجات طالبات المجموعة التجريبية والمجموعة الضابطة في اختبار مفاهيم علم الفرائض البعدي لصالح المجموعة التجريبية". اختبار (ت) لتوضيح الفروق بين مجموعتي البحث التجريبية والضابطة في القياس البعدي لاختبار مفاهيم علم الفرائض لطالبات الثريعة والقانون: 


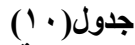

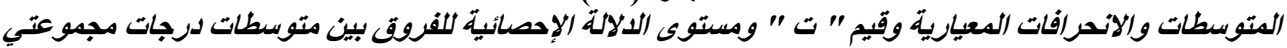

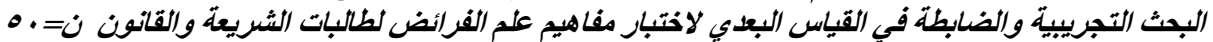

\begin{tabular}{|c|c|c|c|c|c|c|}
\hline $\begin{array}{l}\text { الدلالة) } \\
\text { (Sig) }\end{array}$ & قيمة (ت) & الحرية & المعياري & المتوسط & المجموعة & أبعاد الاختبار \\
\hline \multirow{2}{*}{ دالة"...' } & \multirow{2}{*}{$11 . \cdot 11$} & \multirow{2}{*}{$9 \wedge$} & 1.100 & ะ.74. & التجريبية & \multirow[t]{2}{*}{ الإرث بالفرض } \\
\hline & & & $. V \backslash \leq$ & $\cdot .9 \wedge$. & الضابطة & \\
\hline \multirow{2}{*}{ دالة } & \multirow{2}{*}{$1 \leqslant .117$} & \multirow[t]{2}{*}{91} & .007 & ז.7.. & التجريبية & \multirow{2}{*}{ بالتعصيب الإرث } \\
\hline & & & $\because \Delta \wedge V$ &. .71. & الضابطة & \\
\hline \multirow{2}{*}{ دالة } & \multirow{2}{*}{7.170} & \multirow[t]{2}{*}{91} & $\cdot r v$. & $\because \wedge \varepsilon$. & التجريبية & \multirow{2}{*}{ العصبية } \\
\hline & & &..$\leqslant 1$ & $\because r r$. & الضابطة & \\
\hline \multirow{2}{*}{ '• } & \multirow{2}{*}{$1 \leq .100$} & \multirow[t]{2}{*}{91} & $\cdot r \wedge \theta$ & $1 . \wedge \wedge$. & التجريبية & \multirow{2}{*}{ بالنفس } \\
\hline & & & $.0 \leq \leqslant$ & $\because \leqslant \Lambda$. & الضابطة & \\
\hline \multirow{2}{*}{ دالة } & \multirow{2}{*}{$1 \cdot .0 \leq 0$} & \multirow[t]{2}{*}{91} & .019 & 1.74. & التجريبية & \multirow[t]{2}{*}{ العاصب بغيره } \\
\hline & & & $\because 0 \leqslant Y$ & $\because 0 \leqslant$ & الضابطة & \\
\hline \multirow{2}{*}{ دالة' } & \multirow{2}{*}{11.747} & \multirow[t]{2}{*}{91} & .0 .0 & $1 . V \ldots$ & التجريبية & \multirow{2}{*}{ غيره العاصب مع } \\
\hline & & & $\because 0 \leq \leqslant$ & $\because . \wedge$. & الضابطة & \\
\hline \multirow{2}{*}{ 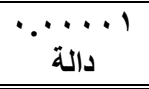 } & \multirow{2}{*}{ V. $\leqslant 4 r$} & \multirow[t]{2}{*}{91} & $\because r v$. & $\because \wedge \varepsilon$. & التجريبية & \multirow{2}{*}{ بوصفين الميراث } \\
\hline & & & $\because \leqslant r 1$ & $\because Y \leq$. & الضابطة & \\
\hline \multirow{2}{*}{ دالة } & $0 . V 0 \leqslant$ & 91 & $\cdot . \varepsilon$ & $\cdot . \wedge \cdots$ & التجريبية & الحجب \\
\hline & & &. .84 & $\cdot r \ldots$ & الضابطة & \\
\hline$\because \cdots \cdots 1$ & 10119 & 91 & $\because v \leqslant q$ & Y.7ะ. & التجريبية & حجب النقصان \\
\hline دالة & $10 . \wedge 17$ & & $\because 0 \wedge$. & $\because \Delta r^{\circ}$ & الضابطة & \\
\hline & & 91 & $\cdot .7 \cdot r$ & $1.7 \%$ & التجريبية & حجب الحرمان \\
\hline ' & 9.1 .7 & & $\because 0 \mathrm{H}$ & $.0 \Lambda$. & الضابطة & \\
\hline & & 91 &. $.7 \cdot Y$ & $1.7 \%$. & التجريبية & الحواشي \\
\hline دالة & $9 . \leqslant Y 1$ & & $\theta 0 \leq r$ & $\because 0 \leq$. & الضابطة & \\
\hline$\because \cdots \cdots$ & & 91 & .070 & $1 . V \leq$. & التجريبية & أصل المسألة \\
\hline دالة & ז. & & $\because 0 \leq \leqslant$ & $\because 0 \ldots$ & الضابطة & \\
\hline$\because \cdots \cdots 1$ & $v \leqslant 1 \wedge$ & $9 \wedge$ & 9.749 & $1.4 \ldots$ & التجريبية & تصحيج \\
\hline دالة & 8.211 & & $\because 0 \leq \leqslant$ & $\because \Delta r$. & الضابطة & المسألة \\
\hline$\because \cdots \cdots 1$ & 1.94 & 91 & $\because \Delta V Y$ & I.VY. & التجريبية & العول \\
\hline ل دالة & 1.91. & & $.0 \leq \leqslant$ & $.0 \cdots$ & الضابطة & \\
\hline$\because \cdots \cdots 1$ & $10 \wedge \leqslant 9$ & 91 & $\because V \nabla r$ & Y.7Y. & التجريبية & الكلالة \\
\hline دالة & & & $\because 0 \leq Y$ & $\because 0 \leq$ & الضابطة & \\
\hline$\because \cdots \cdots$ & & 91 & I.YVO & 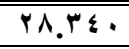 & التجريبية & \\
\hline دالة & 1. & & $0.9 r \Lambda$ & V.VY. & الضابطة & \\
\hline
\end{tabular}

باسـتقراء التتائج المعروضـة بالجدول ( . 1) اتضـح وجـود فـرق دال إحصـائياً عند مسـتوى

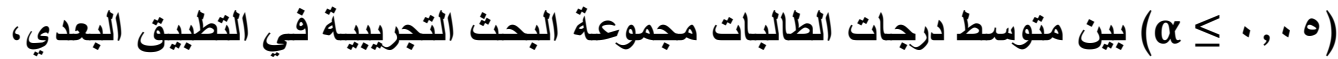
ومتوبـط درجـات مجموعـة البحث الضـابطة في التطبيق البعدي على اختبـار مفـاهيم علم 
الفرائض لطالبات الثريعة والقانون ككل ؛ والمفاهيم الفرعية المكونـة لهه: (الإرث بالفرض الإرث بالتعصيب - العصبة النسبية - العاصب بـالنفس- العاصب بغيرهـ العاصب مي غي غيره-

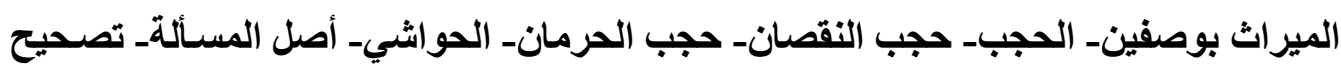

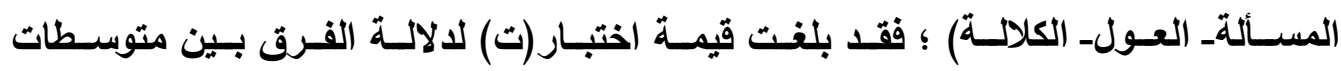

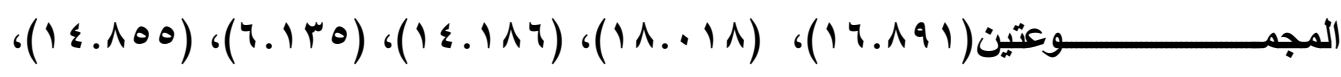

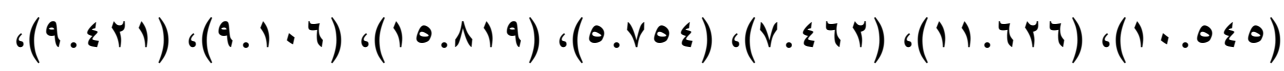

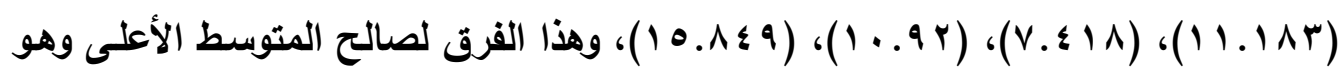
المجموعة التجريبية. وهنا يمكتنا القول بأن إستراتيجية دائرة التعلم المدعومـة بالأنشطة الإثرائية التقتية كانت

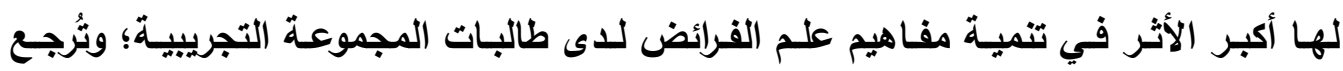
الباحثة تفوق المجموعة التجريبية على الضـابطة في التطبيق البعدي لاختبار مفاهيم علم

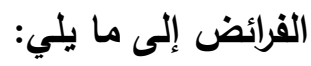

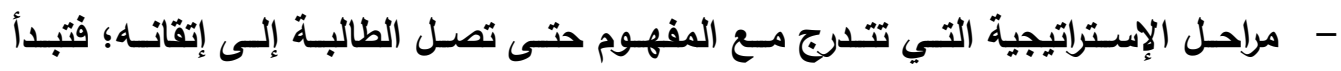

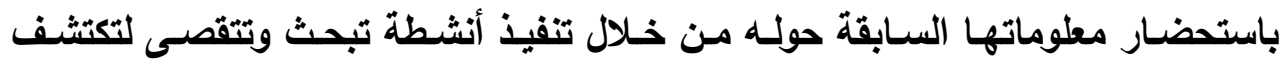
الجديد حول المفهوم، ثم تنبي تعلمها الجديد على خبرتها السـابقة فيتكون لديها إطار مفاهيمي متكامل عن المفهوم، ثم تأتي مرحلة تطبيق المفهوم حيث تتوسـع الطالبة في تطبيق أنشطة تخص المفهوم تزيد من خبرتها، وتنمي لايها مهارات الاستقراء والاستنتاج والبرهان الرياضي والنمذجة بما يثري المفهوم ويحقق عمقًا في فهمه.

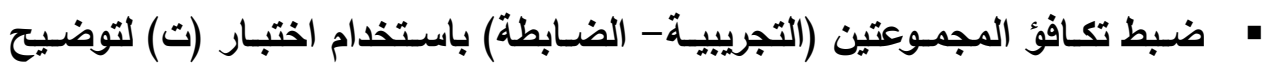
الفـروق بـين مجمـوعتي البحث التجريبيـة والضـابطة فـي القيـاس القبلـي لاختبـار مهارات التفكير الرياضي: لتعرّف تكافؤ المجموعتين التجريبية والضابطة، والحصول على المعلومات القبلية التي

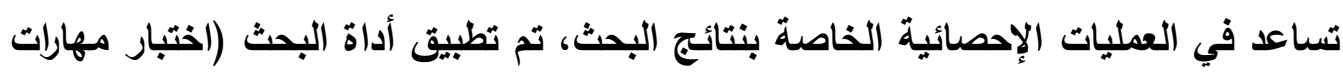
التفكير الرياضي) قبليًا على الطالبات مجموعتي البحث، ثم مقارنة نتائج القياس القبلي لئي للمجموعتين التجريبية والضابطة لتعرّف الدلالة الإحصائية للفرق بين متوسطات درجات أفراد 
المجموعتين، وذلك باستخدام اختبار (ت)، وكاتت نتائج القياس القبلي للمجموعتين كما في

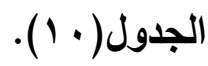

جدول(1) (1)

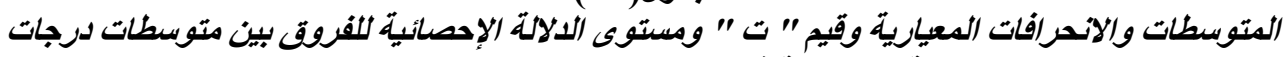

\begin{tabular}{|c|c|c|c|c|c|c|}
\hline $\begin{array}{l}\text { الدلالة } \\
\text { (Sig) }\end{array}$ & قيمة (ت) & لدرجة & المعياري & المتوسط & المجموعة & \\
\hline \multirow{2}{*}{ غير دالة } & \multirow[t]{2}{*}{$\because r \cdot V$} & \multirow{2}{*}{$9 \wedge$} & $.9 V$ & 9.14 & التجريبية & \multirow{2}{*}{ استقراء } \\
\hline & & & .97 & $\cdot \Delta r$ & الضابطة & \\
\hline \multirow{2}{*}{ غير دالة } & \multirow{2}{*}{$\cdot \varphi^{\prime} \varepsilon_{-}$} & \multirow[t]{2}{*}{91} & 1.01 & Y.•? & التجريبية & \multirow{2}{*}{ استنتاج } \\
\hline & & & $1 . \leqslant r$ & Y. I. & الضابطة & \\
\hline \multirow{2}{*}{ غير دآلة } & \multirow{2}{*}{$\because \leqslant \vee \theta_{-}$} & \multirow[t]{2}{*}{91} & •. & $. .1 \leqslant$ & التجريبية & \multirow{2}{*}{ رياضي } \\
\hline & & & . $\leqslant \leqslant$ & .11 & الضابطة & \\
\hline \multirow{2}{*}{ غير دالة } & \multirow{2}{*}{$\because \leqslant 00_{-}$} & \multirow[t]{2}{*}{91} & $\because . r \cdot$ & 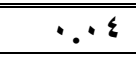 & التجريبية & \multirow{2}{*}{ نمذجة } \\
\hline & & & $\cdot . Y \leqslant$ & $\because .7$ & الضابطة & \\
\hline \multirow{2}{*}{ غير دالة } & \multirow{2}{*}{$\because$ ฯฯム } & \multirow[t]{2}{*}{$9 \wedge$} & $1.0 Y$ & $r . .1$ & التجريبية & \multirow{2}{*}{ المجموع } \\
\hline & & & $1 . \leq 7$ & 5.17 & الضابطة & \\
\hline
\end{tabular}

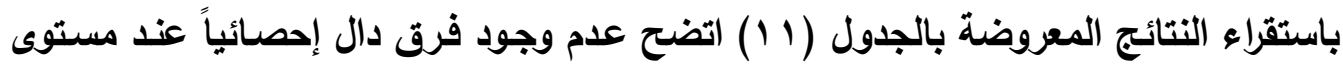

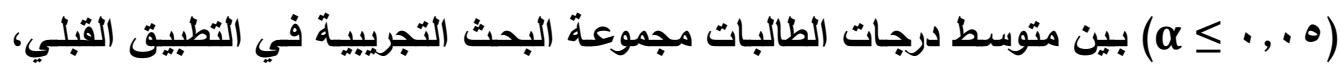
ومتوسط درجات مجموعة البحث الضابطة في التطبيق القبلـي على اختبار مهارات التفكير

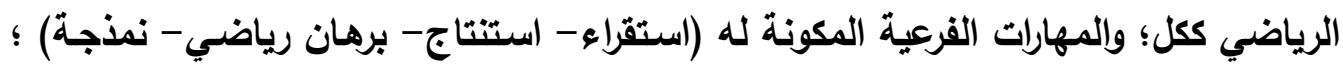

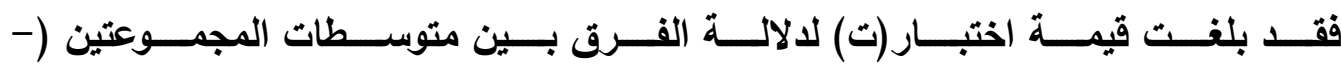

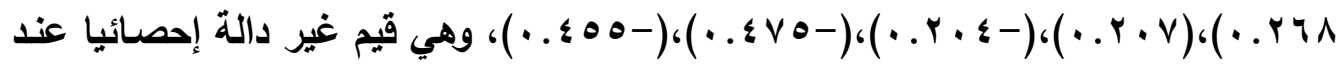
مستوى (0 . . . = م). ويؤكد ذلك على تكافؤ مجموعتي البحث. • اختبار صحة الفرض الثالث: والذي نص على: "وجود فرق ذو دلائة إحصائية عند مستوى (0 . . ) أو أقل بين متوسطي درجات طالبات المجموعة التجريبية في التطبيقين القبلي والبعدي لاختبار مهارات التفكير الرياضي لصالح التطبيق البعدي". للتحقق من صحة هذا الفرض تم استخدام اختبار (ت) لمعرفة دلالة الفروق بين متوسط درجات طالبات المجموعة التجريبية في التطبيقين القبلي والبعدي لاختبار مهارات التفكير الرياضي، والجدول التالي يوضـح ملخص النتائج التي تم التوصل إليها. 
جدول(r) ( ) (1)

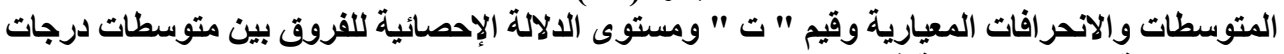

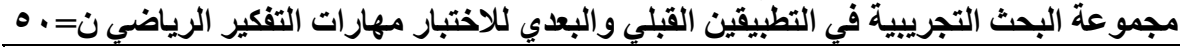

\begin{tabular}{|c|c|c|c|c|c|c|}
\hline (الدلالة & قيمة (ت) & درجة & المعياري & المتوسط & التطبيق & \\
\hline \multirow{2}{*}{ ' } & \multirow{2}{*}{ ro.i1so } & \multirow{2}{*}{$\leq 9$} & .999 & $\cdot . \wedge 4$ & قبلي & \multirow{2}{*}{ استقراء } \\
\hline & & & 1.87 & 9.17 & بعدي & \\
\hline \multirow{2}{*}{ 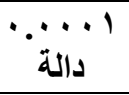 } & \multirow{2}{*}{$r_{0} . \wedge r_{-}$} & \multirow[t]{2}{*}{$\varepsilon 9$} & 1.011 & 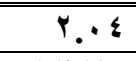 & قبلي & \multirow{2}{*}{ استتتاج } \\
\hline & & & I.MYY & $1 Y . V \leq$ & بعدي & \\
\hline \multirow{2}{*}{ د'” } & \multirow{2}{*}{ r } & \multirow[t]{2}{*}{$\leqslant 9$} & $\because \leqslant .0$ & $.1 \leq$ & قبلي & \multirow{2}{*}{ برياضي } \\
\hline & & & $\because .990$ & $\Lambda . r$ & بعدي & \\
\hline \multirow{2}{*}{ 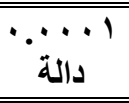 } & \multirow{2}{*}{$\varepsilon v . q \cdot v$} & \multirow[t]{2}{*}{$\leqslant 9$} & .191 & 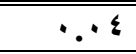 & قَبلي & \multirow{2}{*}{ نمذجة } \\
\hline & & & $\because 9 \cdot \varepsilon$ & 7 & بعدي & \\
\hline \multirow{2}{*}{ دالة' } & \multirow{2}{*}{$9 . \overline{-}(\mathrm{D}$} & \multirow[t]{2}{*}{$\$ 9$} & $1.0 Y \mu$ & $r . \cdot 1$ & قُبلي & \multirow{2}{*}{ المجموع } \\
\hline & & & l.Aor & rT.Y & بعدي & \\
\hline
\end{tabular}

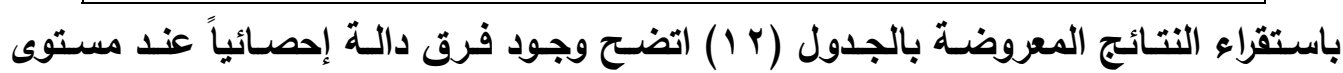

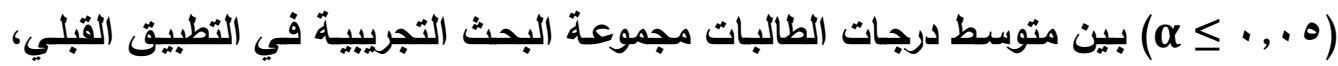
ومتوسط درجاتهم في التطبيق البعدي على الاختبار ككل لصالح التطبيق البعدي؛ فقد بلغت

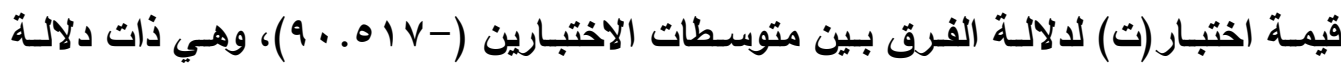

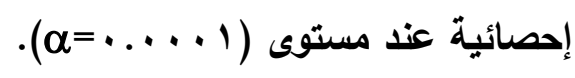
كمـا تضـمن اختبار مهارات التفكير الرياضـي؛ مهارات (استقراء- استتنتاج- برهـان رياضي - نمذجة) والتي أمكن عرض نتائجها فيما يلي: فئي

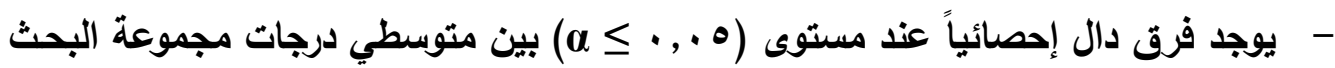
التجريبية في التطبيقين القبلي والبعدي بالنسبة لمهارة الاستقراء لصالح التطبيق البعدي؛

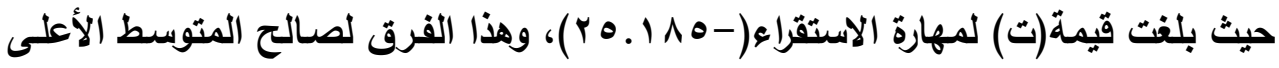
وهو التطبيق البعدي.

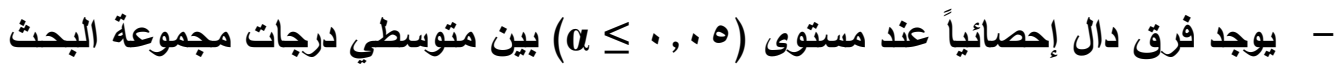

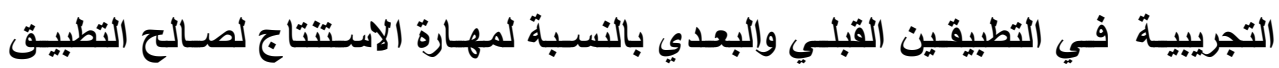

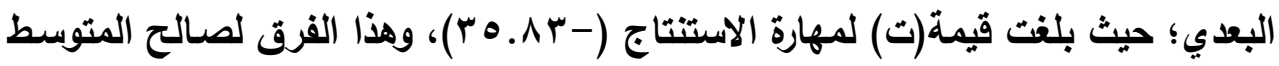
الأعلى وهو التطبيق البعدي. 
- يوجد فرق دال إحصائياً عند مستوى (ه . , . التجريبية في التطبيقين القبلي والبعدي بالنسبة لمهارة البرهان الرياضسي لصالح التطبيق

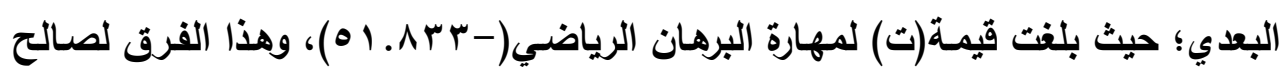
المتوسط الأعلى وهو التطبيق البعدي.

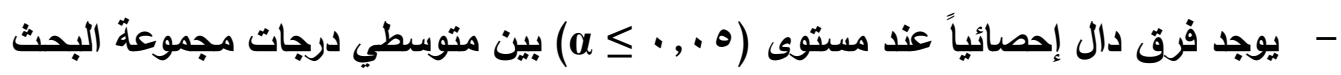

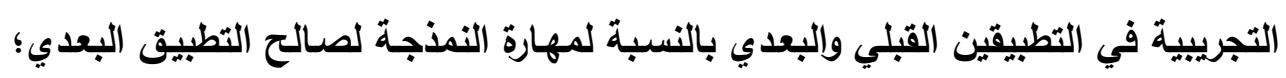

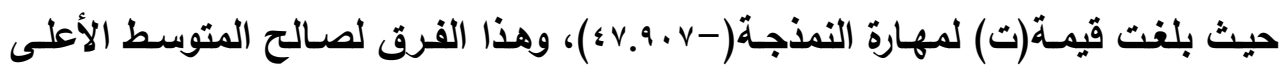

$$
\text { وهو التطبيق البعدي. }
$$

ويوضتح الشكل التالي التمثيل البياني لقيم متوسطات درجات أفراد مجموعة البحث

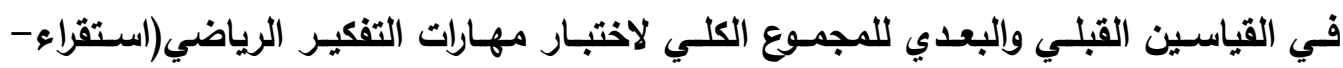
(ستتتاج- برهان رياضي - نمذجة):

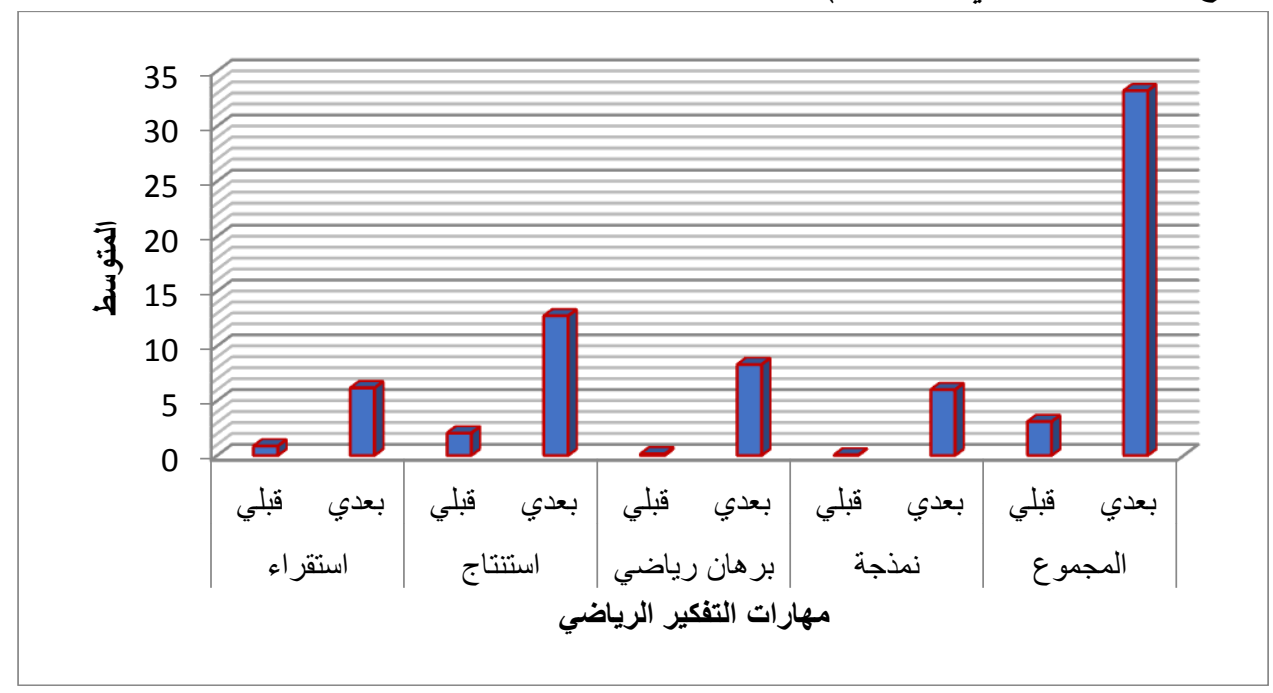

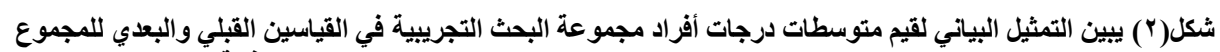

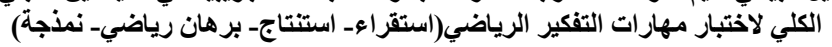

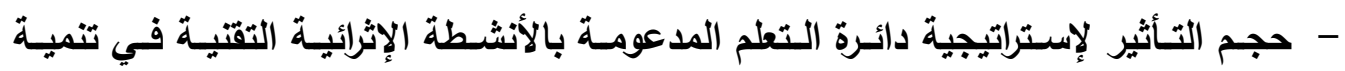
مهارات التفكير الرياضي لاى مجموعة البحث التجريبية: 


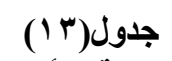

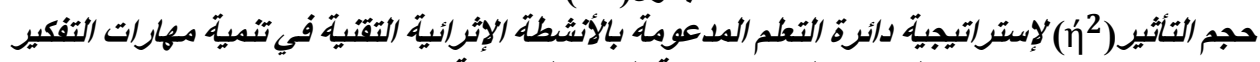

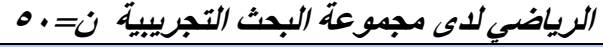

\begin{tabular}{|c|c|c|c|c|}
\hline مستوى حجم الأر & مربع إيتا ( & قيمة " ت " & ح.د & المهارة \\
\hline كبير & $\because \wedge \vee r$ & ro.1110 & $\leqslant 9$ & استقراء \\
\hline كبير & $\because 9 r 0$ & ro.Ar.- & $\leq 9$ & استنتاج \\
\hline كبير & $.97 v$ & $01 . \wedge r r-$ & $\leq 9$ & الزياضي \\
\hline كبير & .900 & $\leq v_{0} q \cdot v_{-}$ & $\leqslant 9$ & النمذجة \\
\hline كبير & $\because .9 \wedge \wedge$ & $9 . .01 v_{-}$ & $\leqslant 9$ & الاختبار ككل \\
\hline
\end{tabular}

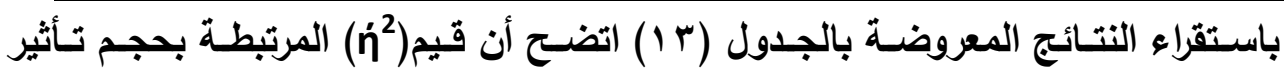
إسـتراتيجية دائرة التعلم المدعومـة بالأنشطة التقنيـة على مهـارات اختبـار التفكير الرياضسي

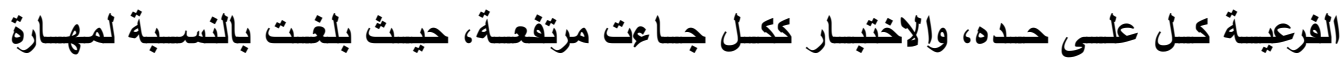

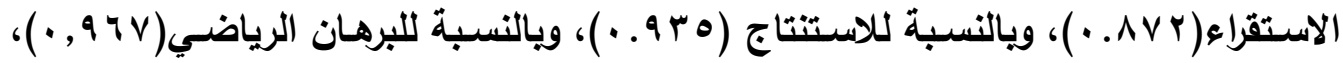

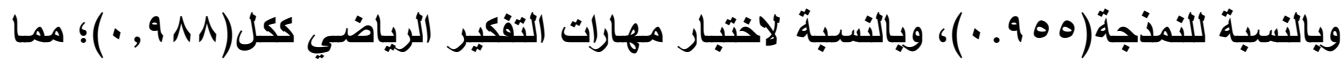

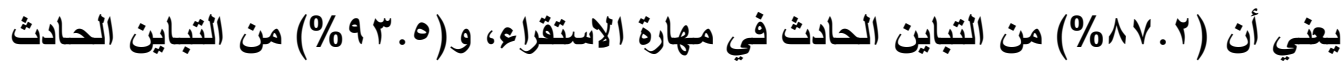

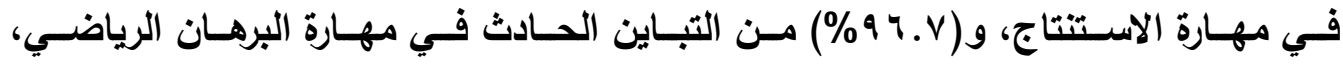

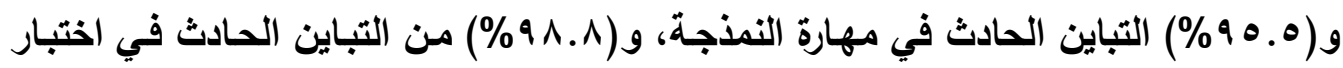
مهارات التفكير الرياضي ككل، ترجع جميعها إلى إستراتيجية دائرة التعلم المدعومـة بالأنشطة التقنية. • اختبار صحة الفرض الرابع: نص الفرض الثاني على: "وجود فرق ذات دلالة إحصائية بين متوسطي درجات طالبات المجموعة التجريبية والمجموعة الضابطة في اختبار مهارات التفكير الرياضي البعدي لصالح المجموعة التجريبية". للتحقق من صحة هذا الفرض، تم استخدم اختبار (ت) لمعرفة دلالة الفروق بين متوسطات درجات طالبات المجموعة التجريبية والمجموعة الضابطة في اختبار مهارات

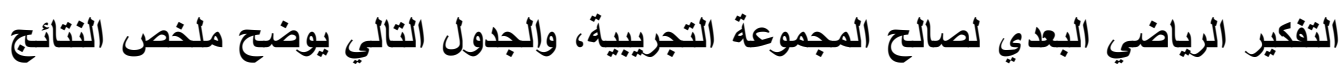


التي تم الحصول عليها.

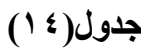

المتوسطات والأحرافات المعيارية وقيم" ت " ومستوى الدلالة الإحصائية للفروق بين متوسطات درجات

\begin{tabular}{|c|c|c|c|c|c|c|}
\hline $\begin{array}{l}\text { الدلالة } \\
\text { (Sig) }\end{array}$ & قيمة (ت) & لدرجة & المعياري & المتوسط & المجموعة & \\
\hline \multirow{2}{*}{ دالة } & \multirow{2}{*}{$r . v \cdot \Lambda$} & \multirow{2}{*}{91} & 1.11 & 7.17 & التجريبية & \multirow{2}{*}{ استقراء } \\
\hline & & & $1 . r \varepsilon$ & $0 . Y 4$ & الضابطة & \\
\hline \multirow{2}{*}{ دالة' } & \multirow{2}{*}{$9.9 \vee \leq$} & \multirow[t]{2}{*}{91} & $1 . r Y$ & IY.V & التجريبية & \multirow{2}{*}{ استنتاج } \\
\hline & & & $1 . r \Lambda$ & $1 \cdot . \cdot \varepsilon$ & الضابطة & \\
\hline \multirow{2}{*}{ دالة' } & \multirow{2}{*}{$10 . V \cdot r$} & \multirow[t]{2}{*}{91} &. .99 & A.r. & التجريبية & \multirow{2}{*}{ برياضي } \\
\hline & & & 1.5 & $\varepsilon . \leqslant \wedge$ & الضابطة & \\
\hline \multirow{2}{*}{ ' } & \multirow{2}{*}{ דצY I I } & \multirow[t]{2}{*}{91} & $\because 9$. & I.*. & التجريبية & \multirow{2}{*}{ نمذجة } \\
\hline & & & 1.91 & r.rq & الضابطة & \\
\hline \multirow{2}{*}{ دالة' } & \multirow{2}{*}{ Rr.rqA } & \multirow[t]{2}{*}{$9 \wedge$} & 1.10 & Tr.Y. & التجريبية & \multirow{2}{*}{ المجموع } \\
\hline & & & Y. $\leqslant V$ & rr.. \& & الضابطة & \\
\hline
\end{tabular}

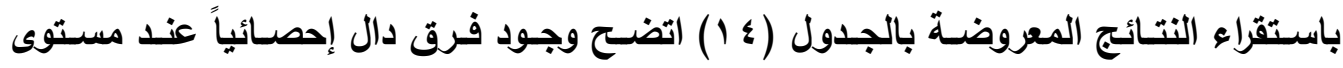

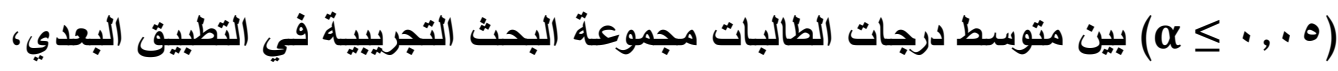
ومتوسط درجات مجموعة البحث الضـابطة في التطبيق البعدي على الاختبار ككل لصـالح المجموعة التجريبية؛ فقد بلغت قيمـة اختبار(ت) لدلالـة الفرق بين متوسطات المجموعتين

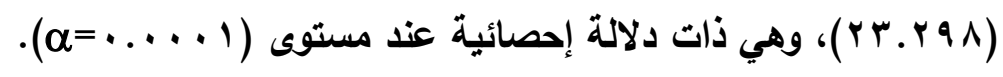
كمـا تضـمن اختبـار مهارات التفكير الرياضـي؛ مهارات (استقراء- استتنتاج- برهـان رياضي - نمذجة) والتي أمكن عرض نتائجها فيما يلي:

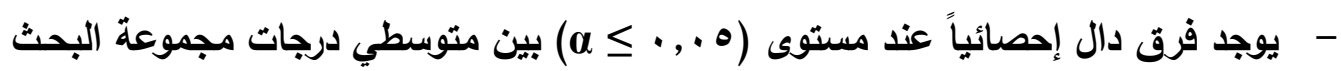

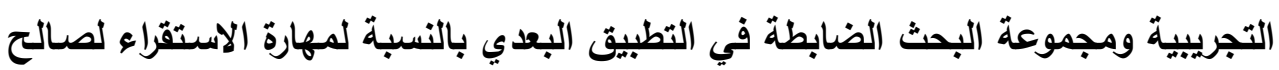

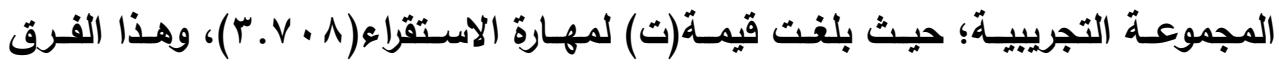
لصالح المتوسط الأعلى وهو المجموعة التجريبية.

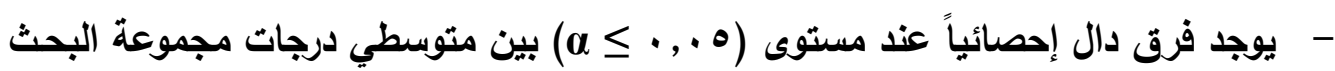
التجريبيـة ومجموعـة البحث الضـابطة في التطبيـق البعدي بالنسـبة لمهـارة الاسـتنتاج

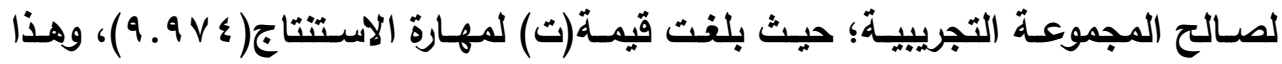
الفرق لصالح المتوسط الأعلى وهو المجموعة التجريبية. 
- - يوجد فرق دال إحصائياً عند مستوى (ه . , .

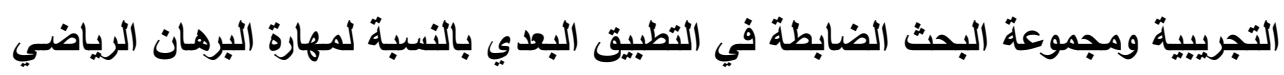

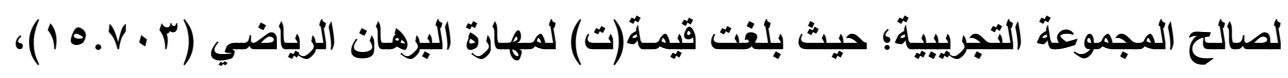
وهذا الفرق لصالح المتوسط الأعلى وهو المجموعة التجريبية.

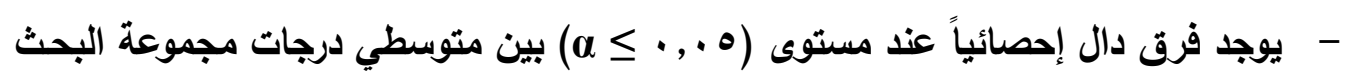

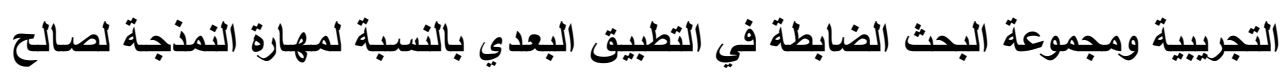

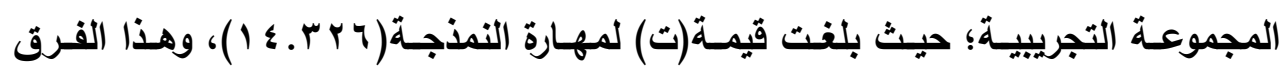

لصالح المتوسط الأعلى وهو المجموعة التجريبية. ويوضـح الثكل التالي التمثيل البياني لقيم متوسطوات درجـات أفراد مجموعتي البحث التجريبيـة والضـابطة في القيـاس البعدي لاختبـار مهارات التفكير الرياضـي للمجمسوع الكلي لئي والمهارات الفرعية (استقراء- استنتاج- برهان رياضي- نمذجة)

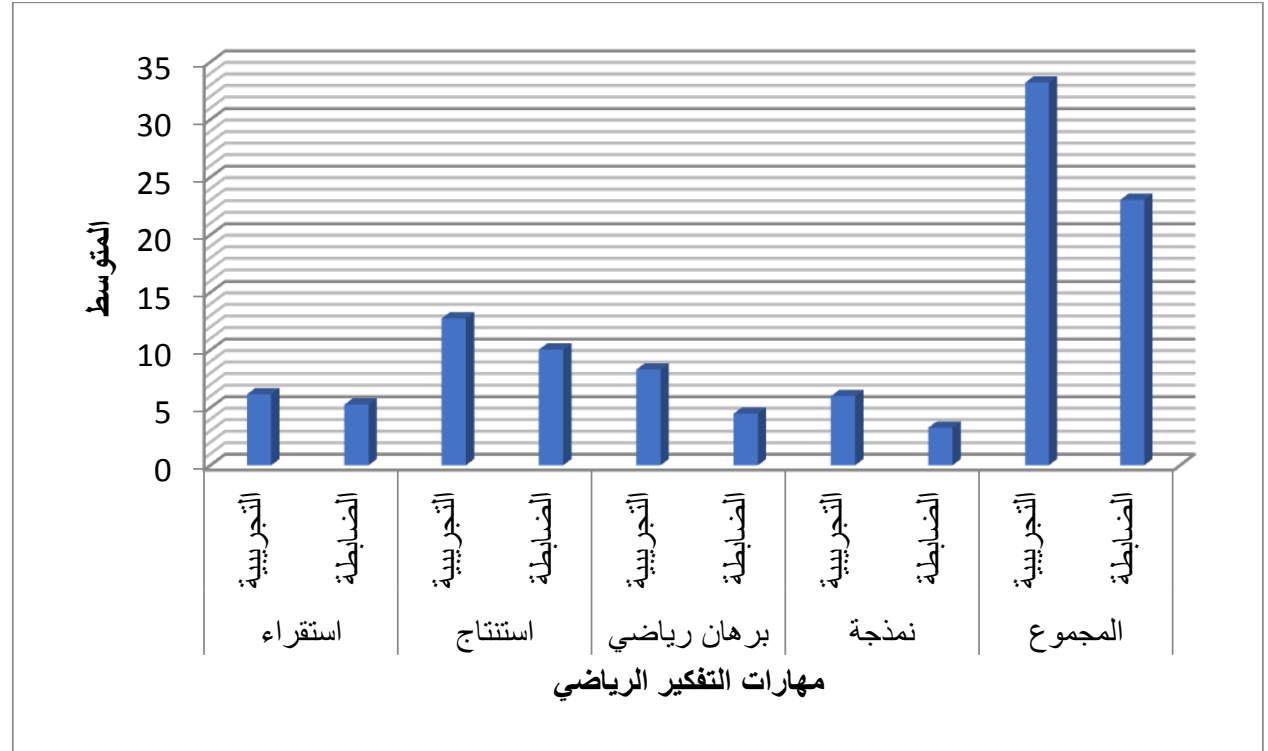

شكل(ب)/التمثيل البياني لقيم متوسطات درجات أفراد مجموعتي البحث التجريبية والضابطة في القياس البعدي لاختبار

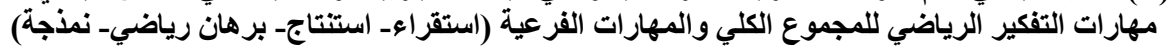

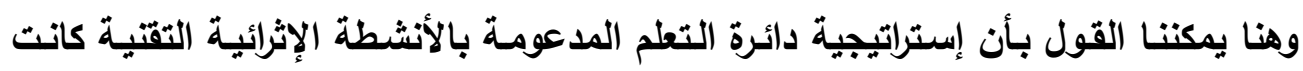

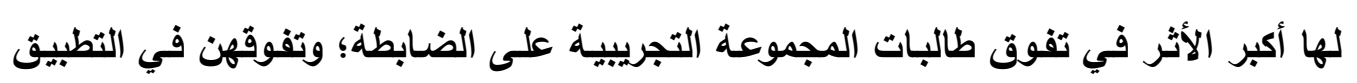
البعدي لاختبار مهارات التفكير الرياضي، وترجع الباحثة هذا التفوق إلى الأسباب الآتية: 
1 - الأنشطة الإثرائية المقدمة للطالبات اهتمت بكل مهارة من مهارات التفكير على حدة فقد بلغت الأنثطة التي اهتمت بمهارة الاستقراء هـ نشاطاً، والأنشطة التي اهتمت بمهارة الاستتتاج · ؛ نشاطا والبرهان الرياضي هب نشاطاً، والنمذجة · ـ نشاط، وذلك بما خلق الفرصة على التدرب على هذه المهارات مما أسهم بشكل واضح في تتميتها. r- وتتفق هذه النتائج مـع مـا توصلت إليهه نتائج كل من: دراسـة (عبد الرحمن بن عبد

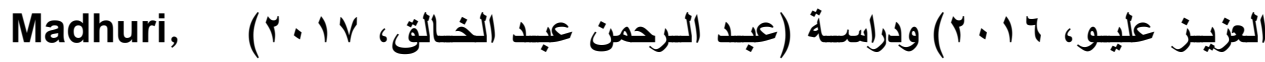
. (Kantamridhi, 2012) r- مراحل الإستراتيجية التي سـاعدت الطالبة على البحث والتقصي لتكوين فهم شـامل عن المفهوم وريـط المعلومـات الجديدة بـالخبرات السـابقة حولـه (استكثــاف المفهوم)، ثم (تقديم المفهوم) بتكوين صورة صحيحة حوله وتنفيذ أنشطة متنوعة تتضمن حل مسائل عديدة ترسخ فهمها له واستقراء المعلومات الخاصة بـه وذكر براهين وأدلة الحل النقلية

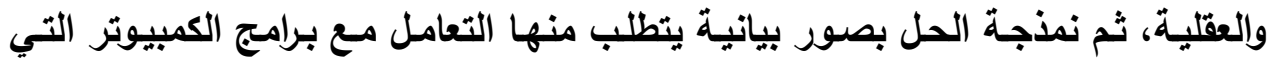
تعينها على ذلك، مما يجعل (تطبيق المفهوم) من خلال مواقف ومشكلات جديدة تعالجها الطالبـة وتطبق المهارات وتحل مسـائل جديدة تتعلق بـالمفهوم؛ أمسر ميسور ويإمكسان

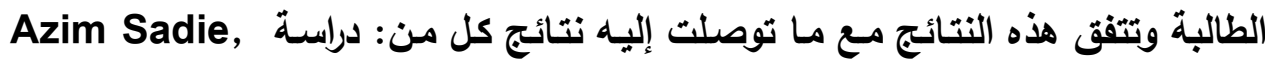
(Patrick Agaga, Ochroko Bravoki, 2012) ودراسة (2010) ـ - نظـام التقـويم والمتابعـة لأنثـطة الطالبـات حيـث تـم التقـويم للمجموعـات مسن خـلال (مسابقات تثجيعية) تقدم فيها كل مجموعة نتيجة عملها ثم تعزز المجموعة الفائزة،

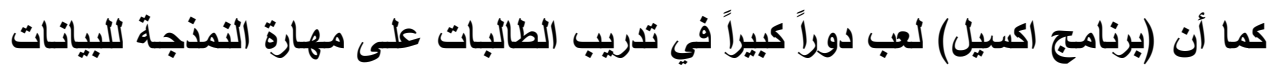

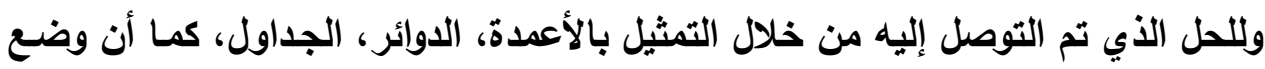
الطالبات في (مواقف واقعية) يطلب منها إعطاء حلول لمشـاكل حقيقية بناء على خبرة سابقة ودراسـة نظريـة للأحوال الشخصية، كل هذا كان لـه أثر داعم في تنمية مهارات التفكير الرياضي لاى الطالبات. ه - قناعـة الطالبـات (المجموعـة التجريبية) بأهميـة تنميـة مهارات التفكير الرياضسي للديهن وحاجتهن للتدريب عليها وتحمسهن لتحقق هدف البحث خاصـة بعدما تم شرح أهمية التجريـة لهن والفائدة التطبيقية التي تعود عليهن نتيجة التدريب على مهارات التفكير 
الرياضـي خاصـة بعد التخرج ممـا يسهل عليهن الانخراط في المجتمع وشـلل الوظائف المطلوية وتحقيق الكفاءة المرجوة.

צ- روح التعـاون بين المجموعـات الصغيرة والتـي يتشـم بها العمل التعـاوني سـهل القيـام

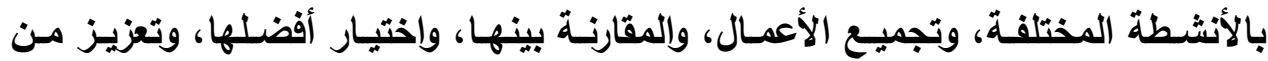

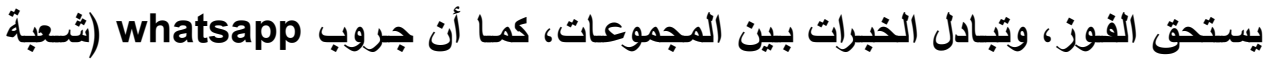
الثريعة والقانون) الذي كان له دور كبير في تنفيذ الأنثطة وتحديد أوقات المحاضرات وتلقي الأعمـال وتصـيحها ومتابعة الواجبـات والتكليفـات كل هذا سـهل على لـى الباحثة

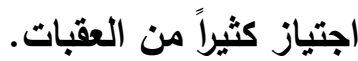

V - التسـهيلات المقدمـة مـن كليـة البنـات الإسـلامية للباحثة بالموافقة على تطبيتق البحث

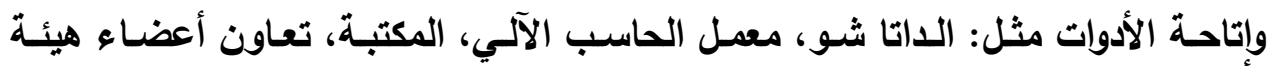

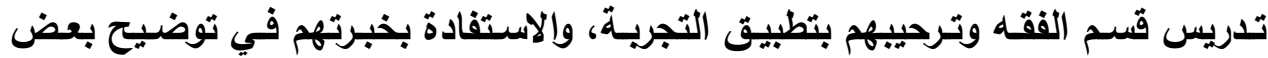
المفـاهيم والمسـائل كـان لـه أكبر الأثخر في نجـاح التجربـة وتفـوق طالبـات المجموعـة

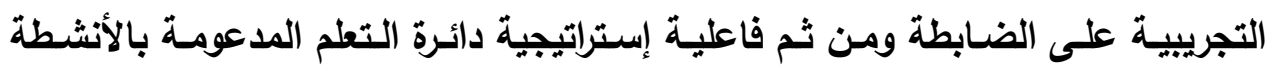
الإثرائية التقتية لتنمية التفكير الرياضي.

\section{العقبات التي واجهت تنفيذالتجربة:}

1 - كثرة الأنشـة الإثرائيـة التقتيـة والحاجـة إلى متابعـة الطالبـات وتقويم أدائهـن بعد المحاضرات وقد تم التظلب على ذلك من خـلال جروب whatsapp (شعبة الثريعة

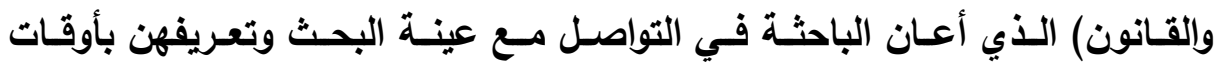
المحاضرات، ومتابعة الأنشطة وتصحيحها، وتعزيز المجموعات الفائزة. r - الحاجة لتوفير محاضرات وجهاً لوجه مع عينة البحث لشرح المفاهيم وتنفيذ الأنشطة

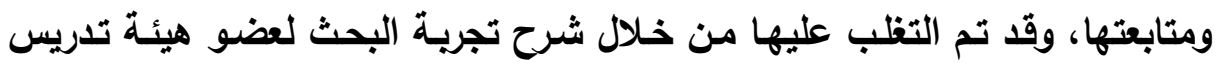

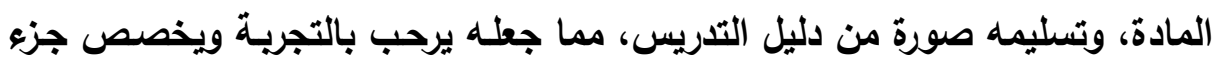
من المحاضرة لتنفيذها.

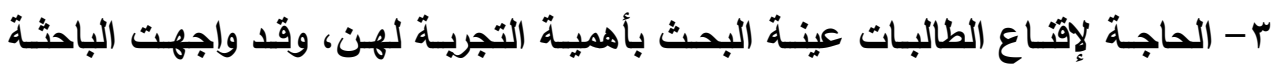
تسـاؤلات عدة من جانبهن عن أهمية مهارات التفكير الرياضس، والأنشطة الإثرائية 
التقتيـة وكيفيـة تنفيذها، وقـد تـم شـرح هدف البحث لهـن وتثـجيعهن مسن خـلال

المسابقات والجوائز .

التوصيات والمقتزحات :

في ضوء ما توصل إليه البحث من نتائج يمكن تقليم التوصيات والمقترحات التالية:

$$
\text { أولاًَ- التوصيات: }
$$

- عقد الدورات التدريبية في كليات الثريعة الإسلامية والثريعة والقانون لأعضاء هيئة تدريس (الفقه والأحوال الثخصية للمسلمين) لتعرف فلسفة إستراتيجية دائرة التعلم المدعومة بالأنشطة الإثرائية التقنية وكيفية تطبيقها. - - تبني الاستراتيجيات والنماذج التي تهتم بتنمية التفكير ودور الطالب الإيجابي في التدريس الجامعي مثل إستراتيجية دائرة التعلم المدعومة بالأنثطة الإثرائية التقتية.

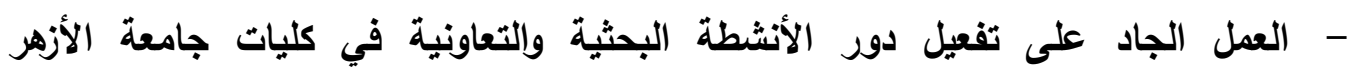
والاستفادة بالمكتبات والمعامل ومواقع التواصل الاجتماعي في تتمية مهارات التفكير المختلفة.

- إدراج إستراتيجية دائرة التعلم المدعومة بالأنشطة الإثرائية التقنية ضمن محتوى مادة طرائق التدريس في كليات التربية. - عقد الندوات والدورات التدريبية لمعلمي التربية الدينية الإسلامية؛ في الأزهر الشريف

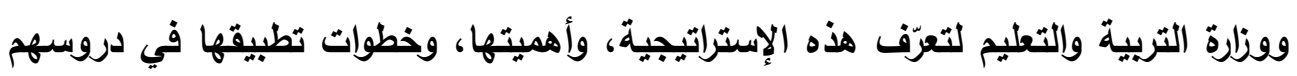
المختلفة. ثانياً - المقترحات: - اجراء دراسة مماثلة تستهدف تنمية التفكير الاستدلالي في مقرر أصول الفقه لاى طالبات الثريعة بجامعة الأزهر باستخدام إستراتيجية دائرة التعلم المدعومة بالأنشطة الإثرائية التقنية - فاعلية إستراتيجية قبعات التفكير الست لتنمية مهارات التفكير الرياضي في مقرر الأحوال الشخصية المواريث لطالبات الثريعة الإسلامية بجامعة الأزهر. - - إعداد برنامج مقترح لتدريب أعضاء هيئة التدريس بكليات الثريعة والقانون على استخدام إستراتيجية دائرة التعلم المدعومة بالأنشطة الإثرائية التقنية. 


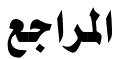

\section{أولاً : المراجع العربية : أمبية}

ا. إبراهيم بن محمد بن إبراهيم الحَلَبي الحنفي (991 (19) "مجمع الأنهر في شرح ملتقى الأبحر" خرج

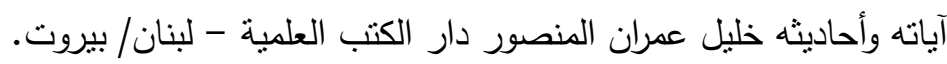

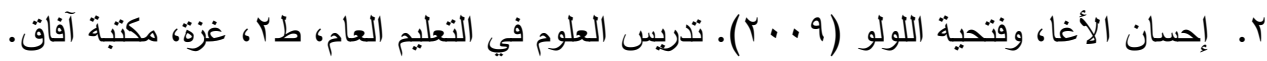

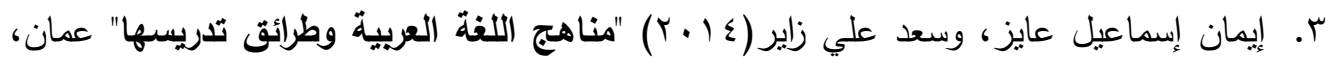
الأردن، دار صفاء للنشر والتوزيع.

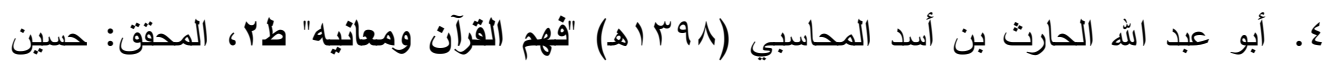
القوتلي، دار الكندي، ودار الفكر ، بيروت.

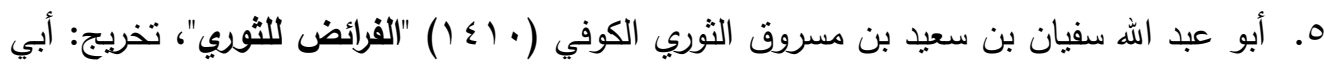

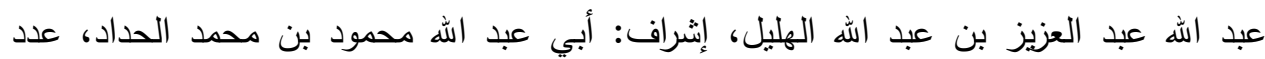
الأجزاء: (، الرياض، دار العاصمة للنشر. T. أبو عبد الله محمد بن إدريس بن العباس بن عنمان بن شافع بن عبد المطلب بن عبد مناف

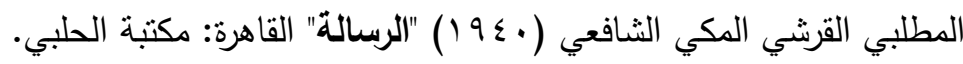

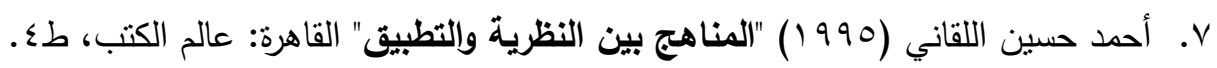

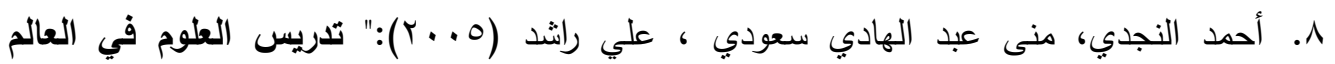
المعاصر - اتجاهات حليثة لتعليم العلوم في ضوء المعايير العالمية وتنمية التفكير والنظرية البنائية "، القاهرة، دار الفكر العربي.

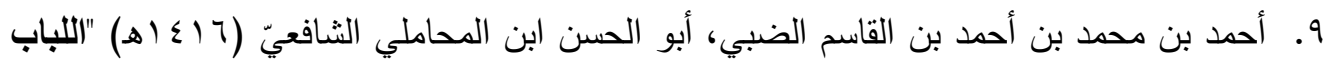

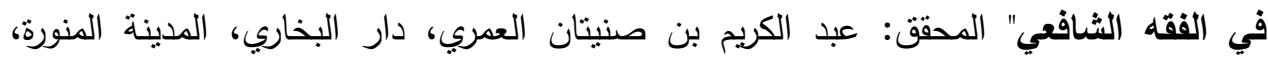
المملكة العربية السعودية. • أ. أحمد جمال الدين محمد أحمد (10 ب ؟) " فاعلية وحدة مقترحة في الرياضيات المجتمعية لتتمية بعض المهارات الحياتية ومهارات التفكير الرياضي لدى تلاميذ المرحلة الابتدائية، رسالة ماجستير غير منشورة، كلية التربية، جامعة أسيوط.

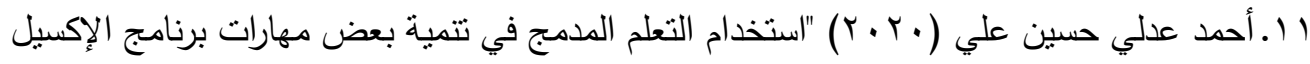
EXCEL منشورة، كلية التربية، جامعة أسيوط. 


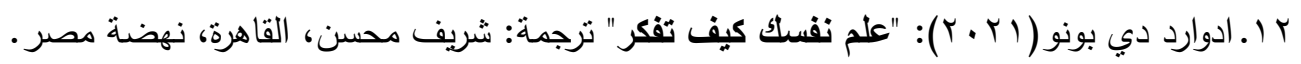

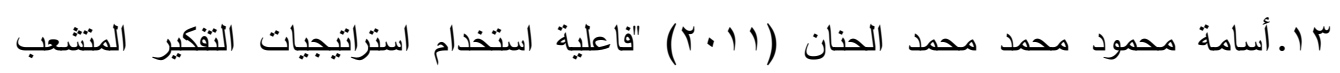
لتدريس الرياضيات في تتمية مهارات البرهان الرياضي والاتجاه نحو التعلم التعاوني لدى تلاميذ التئ المرحلة الإعدادية" رسالة ماجستير غير منشورة، كلية التربية، جامعة أسيوط.

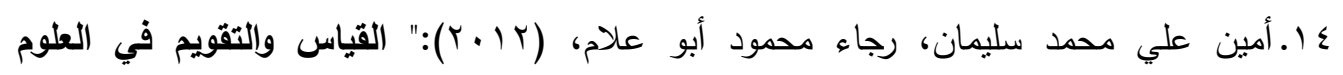
الإنسانية أسسه وأدواته وتطبيقاته "، القاهرة: دار الكتاب الحديث.

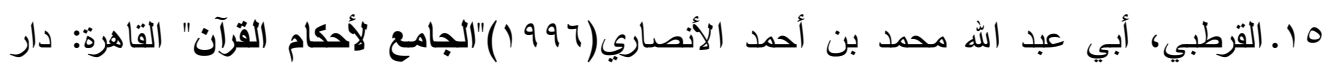
الحديث، طץ.

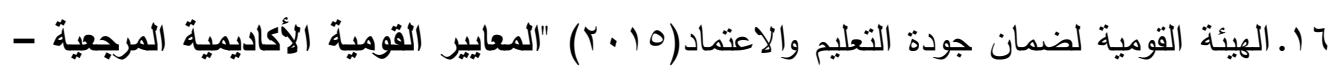

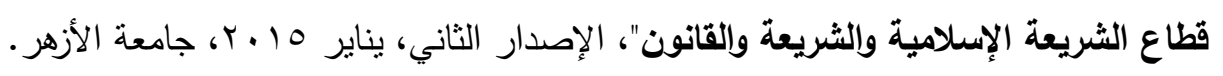

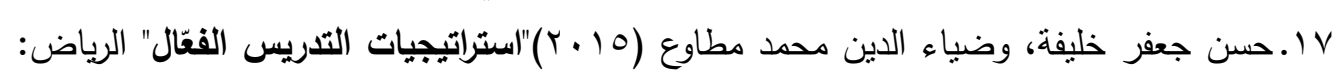
مكتبة المتتبي.

1 ا. حسن حسين زيتون، وكمال عبد الحميد زيتون (1 . ץ):"تصميم البرامج التعليمية بفكر البنائيةتأصيل فكري ويحث إمبريقي " ، القاهرة، عالم الكتب.

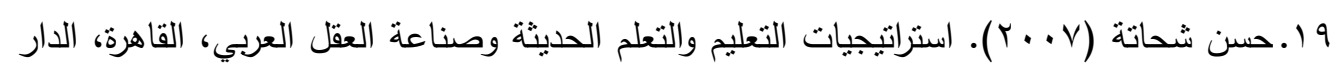
المصرية اللبنانية.

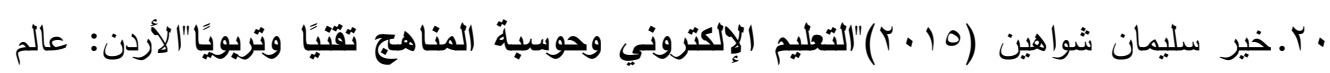
الكتب الحديث للنشر والتوزيع.

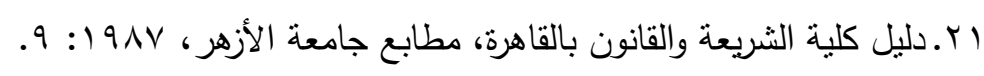

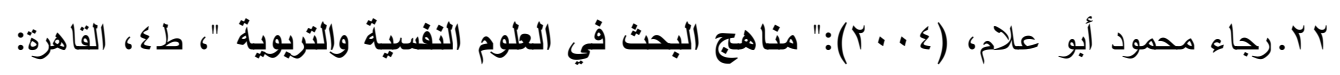

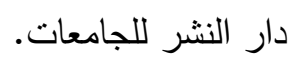

r r. رعد مهدي رزوقي، سهى إبراهيم عبد الكريم(10 • " "التفكير وأنماطه التفكير العلمي- التفكير التأملي - التفكير الناقد - التفكير المنطقي" عمان - الأردن، دار المسيرة للنشر والتوزيع والطباعة.

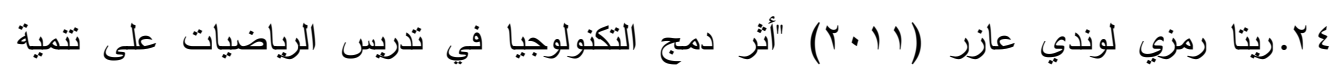

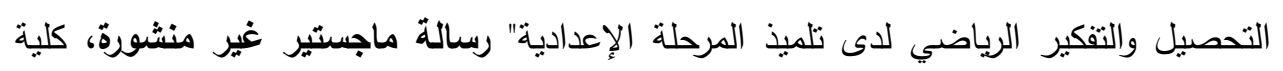
التربية، جامعة أسيوط.

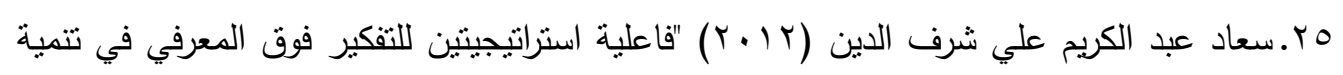

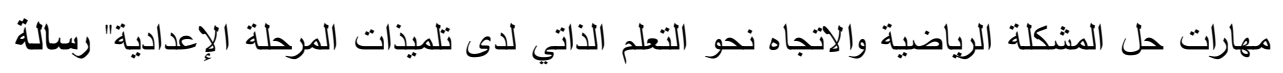


دكتوراه غير منشورة، كلية التربية، جامعة أسيوط.

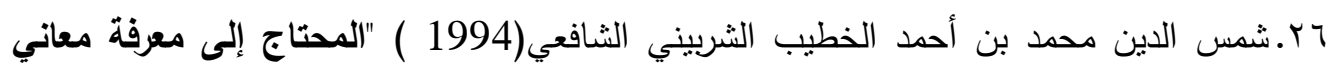

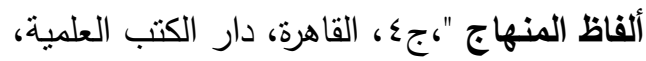

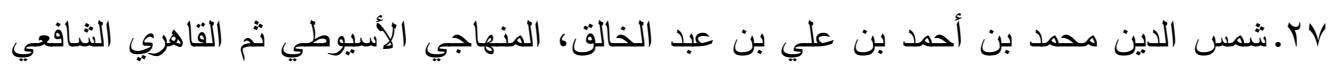

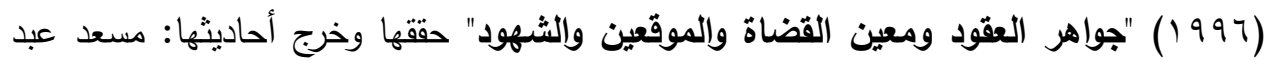
الحميد محمد السعدني، دار الكتب العلمية بيروت - لبنان.

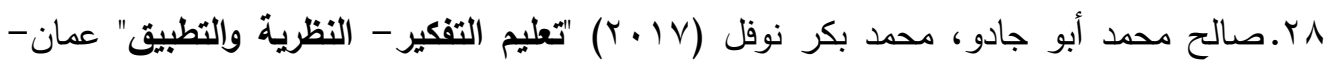
الأردن، دار المسيرة للنشر والتوزيع والطباعة.

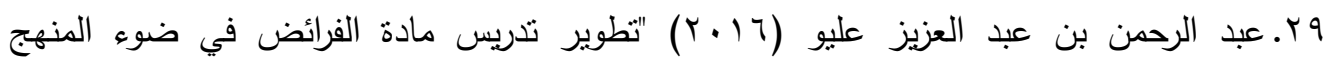
التكاملي بين مادتي الفرائض والرياضيات واحتياجات المتعلمين" رسالة ماجستير، كلية التربئ لتربية، جامعة المدينة العالمية، ماليزيا.

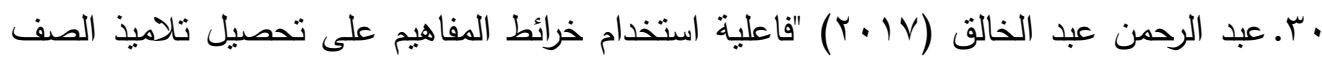

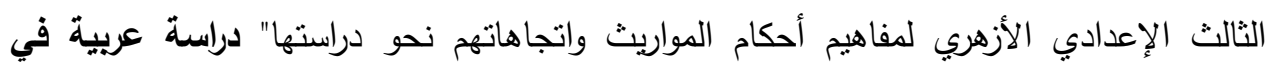

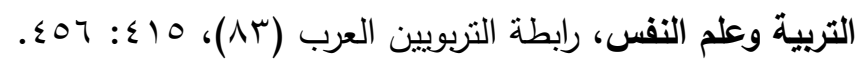

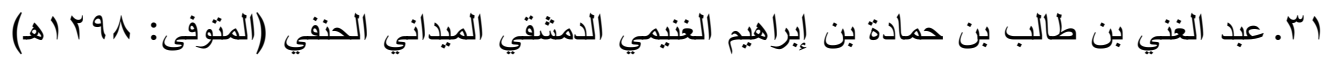

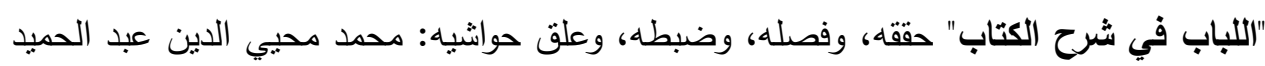
عدد الأجزاء: ع، المكتبة العلمية، بيروت - لبنان r r. عبد الله بن محمود بن مودود الموصلي البلاحي، مجد الدين أبو الفضل الحنفي VTو 19 "الاختيار

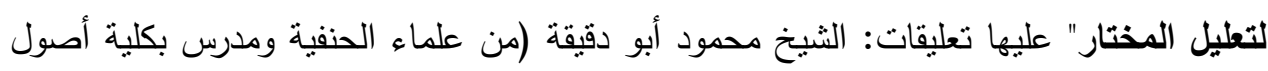
الدين سابقا)الناشر: مطبعة الحلبي - القاهرة (وصورتها دار الكتب العلمية - بيروت، وغيرها)

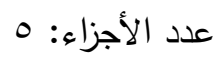

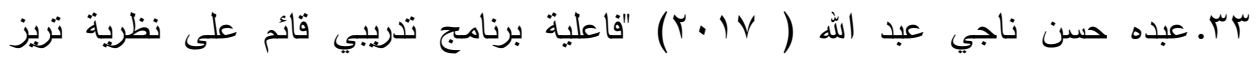
TRIZ

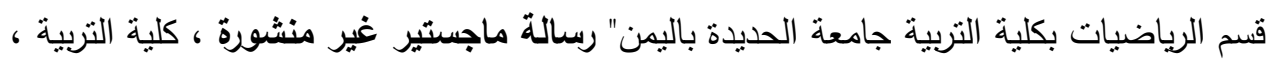
جامعة أسيوط. ـ ז. عفت مصطفى الطناوي (10 • ب): "اتجاهات معاصرة في تدريس العلوم والتربية العملية"، القاهرة، مركز الكتاب.

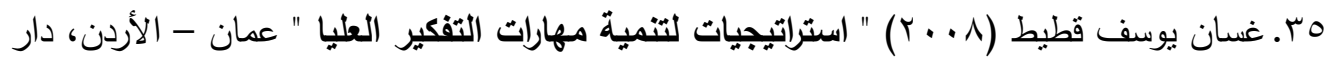




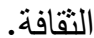

بr. فريد كامل أبوزينة، وعبد اله يوسف عبابنة (V . . Y)" مناهج رياضيات للصفوف الأولى " عمان - الأردن، دار المسيرة للنشر والتوزيع والطباعة.

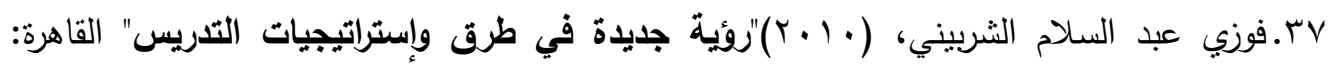
المكتبة العصرية للنشر والتوزيع.

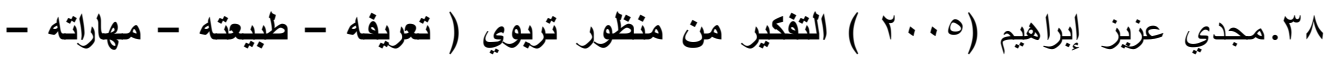

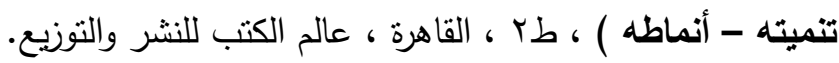

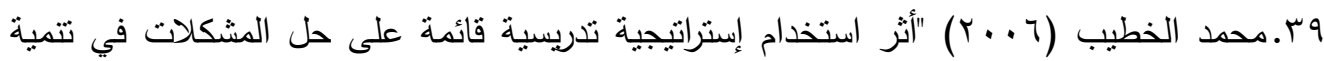

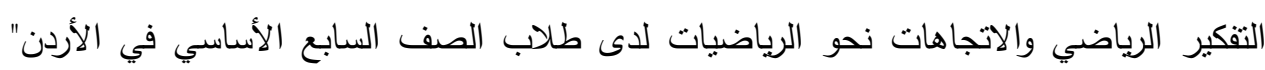
رسالة دكتوراه غير منشورة، الجامعة الأردنية، عمان - الأردن.

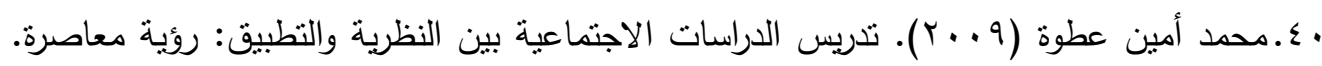
القاهرة، دار السحاب.

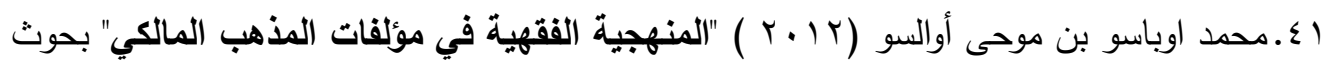

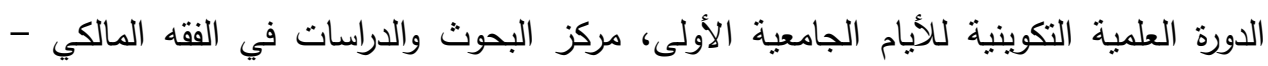

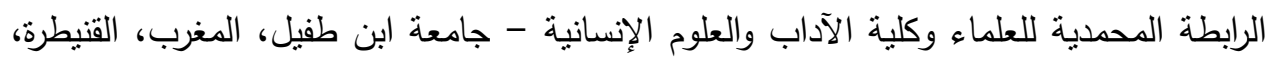

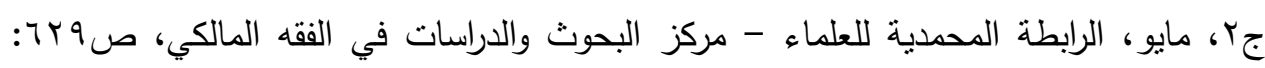
$.7 \leq 9$

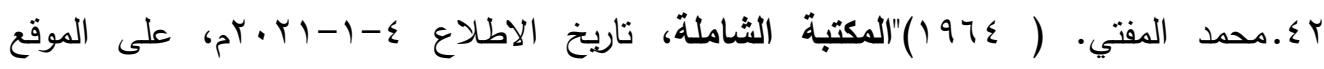
http://www.shamela.ws:النالي

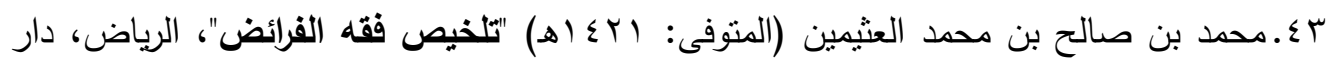

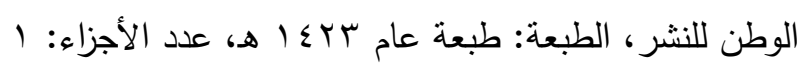

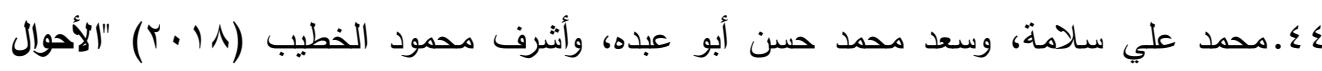

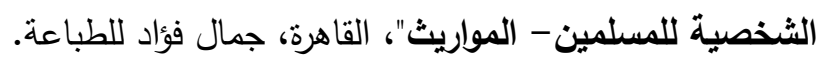

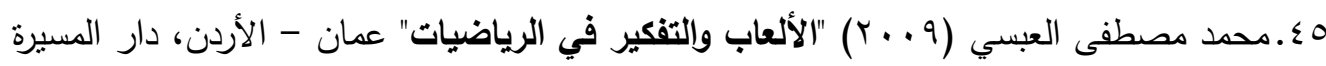
للنشر والتوزيع والطباعة.

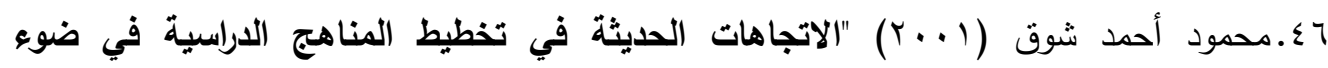
التوجيهات الإسلامية" القاهرة، دار الفكر العربي.

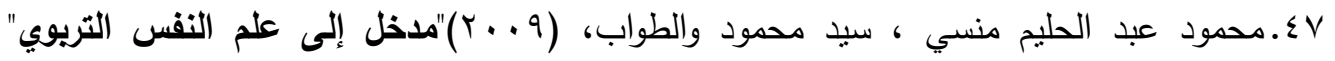




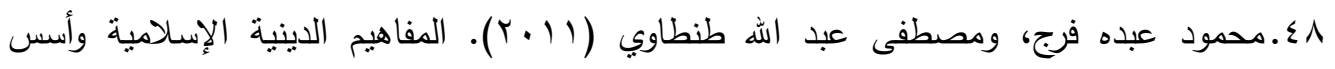

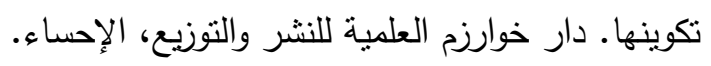

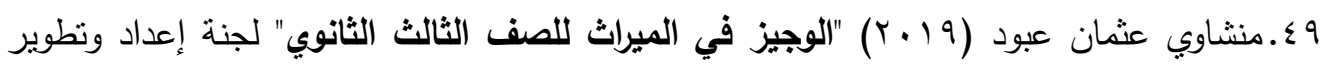

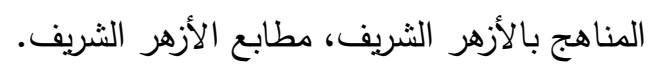

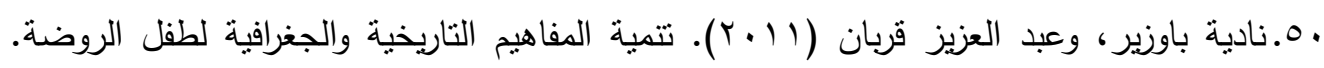

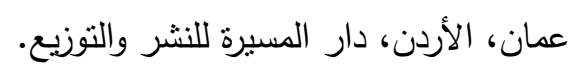

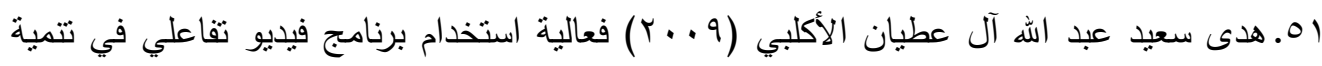

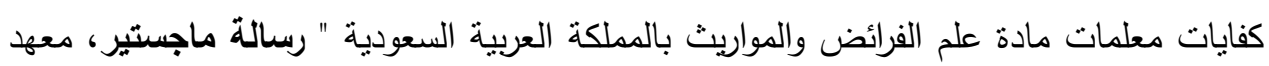
الدراسات والبحوث التربوية بالقاهرة.

r. Y.وليد سالم محمد الحلفاوي (1) (1)"التعليم الإكتروني: تطبيقات مستحدثة" القاهرة: دار الفكر العربي.

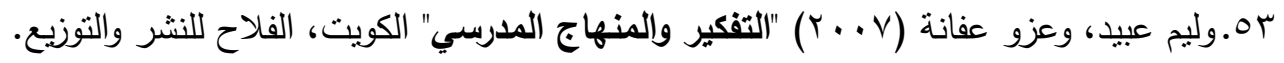

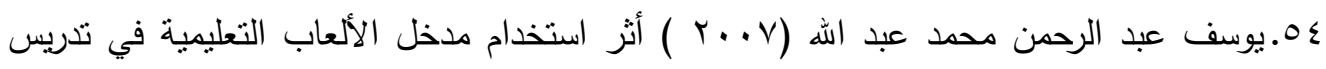

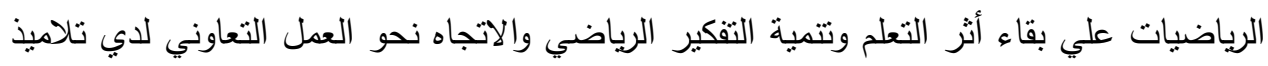
المرحلة الابتدائية، رسالة ماجستير غير منشورة. كلية التربية، جامعة أسيوط.

ثانياً : المراجع الأجنبية :

1- Azim Sadie, (2010) "The effect of the five learning circuits on student achievement in the circulatory system of the human body" Journal of Applied Biological Sciences 4(3):63- 67,

2- Erik D., Veronica, J. Rebecca J. (2007): Integrating delayed dispersal into broader concepts of social group formation .Behavioural Processes, Volume 76, Issue 2, October 2007

3- F-rançois Molle. (2009). River-basin planning and management. The social life of a concept Geoforum, Vol 40, Issue 3, May 2009.484- 494.

4- Patrick Agaga, Ochroko Bravoki, (2012) "The effect of the five-year learning cycle on achievement in biology and chemistry" Cypriot Journal of Educational Sciences volume 7, Issue3, 244-262.

5- Madhuri, Kantamridhi,(2012) "Enhance higher-order thinking skills using inquiry-based learning" European Journal of Engineering Education vol.37,may2012,117-123. 